\title{
Photovoltaic Procurement Strategies: An Assessment of Supply Issues
}

\section{David Posner}

Dennis Costello
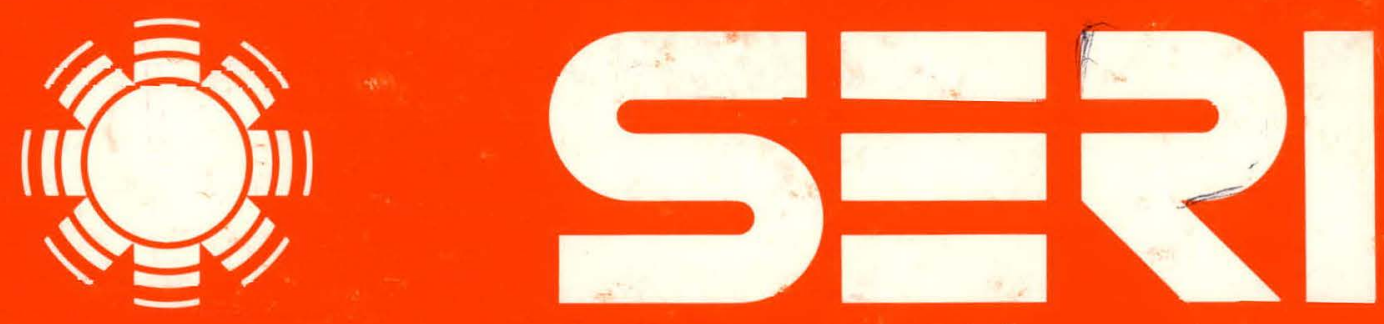

Solar Energy Research Institute

^ Division af Minwest Research Institute

1617 Cole Boulevard

Golden, Colorado 80401

Operated for the

U.S. Department of Energy

under Contract No. EG-77-C-01-4042 


\section{DISCLAIMER}

This report was prepared as an account of work sponsored by an agency of the United States Government. Neither the United States Government nor any agency Thereof, nor any of their employees, makes any warranty, express or implied, or assumes any legal liability or responsibility for the accuracy, completeness, or usefulness of any information, apparatus, product, or process disclosed, or represents that its use would not infringe privately owned rights. Reference herein to any specific commercial product, process, or service by trade name, trademark, manufacturer, or otherwise does not necessarily constitute or imply its endorsement, recommendation, or favoring by the United States Government or any agency thereof. The views and opinions of authors expressed herein do not necessarily state or reflect those of the United States Government or any agency thereof. 


\section{DISCLAIMER}

Portions of this document may be illegible in electronic image products. Images are produced from the best available original document. 
Printed in the United States of America
Available from:
National Technical Information Service
U.S. Department of Commerce
5285 Port Royal Road
Springfield, VA 22161
Price:
Microfiche $\$ 3.00$
Printed Copy $\$ 6.50$

NOTICE

This report was prepared as an account of work sponsored by the United States Government. Neither the United States nor the United States Department of Energy, nor any of their employees, nor any of their contractors, subcontractors, or their employees, makes any warranty, express or implied, or assumes any legal liability or responsibility for the accuracy, completeness or usefulness of any information, apparatus, product or process disclosed, or represents that its use would not infringe privately owned rights. 
SERI/TR-352-298

UC CATEGORY: UC-63a

PHOTOVOLTAIC PROCUREMENT STRATEGIES: AN ASSESSMENT OF SUPPLY ISSUES

DAVID POSNER

DENNIS COSTELLO

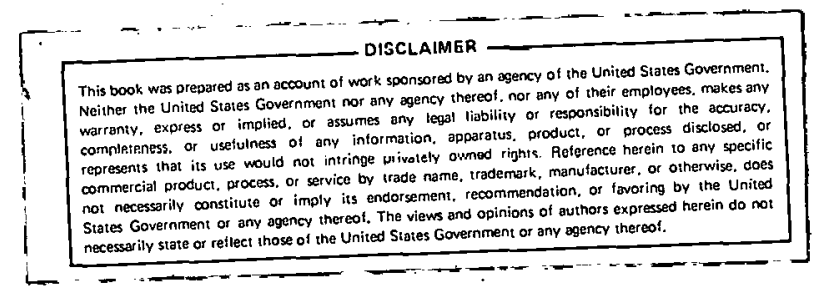

FEBRUARY 1980

PREPARED UNDER TASK NO: 3825.50

\section{Solar Energy Research Institute}

1536 Cole Boulevard

Golden, Colorado 80401

\section{A Division of Midwest Research Institute}

Prepared for the U.S. Department of Energy

ContractNo. EG.77.C.01.4042 


\section{THIS PAGE}

WAS INTENTIONALLY

LEFT BLANK 


\section{FOREWORD}

This report presents the results of a study of alternative government strategies for purchasing photovoltaic modules and systems. It contains a review of procurement policies and programs of other federal agencies (especially the Department of Defense) and the results of interviews with selected companies in the photovoltaic industry. The purpose of the report is to provide the Department of Energy with information useful in defining and implementing future federal procurement programs. Strategies examined herein, however, were devised strictly for analytic purposes and do not reflect current or anticipated DOE policy.

The cooperation of the companies interviewed during this study made this report possible. In addition, members of the Photovoltaics Lead Center at the Jet Propulsion Laboratory, and Paul Maycock and Elaine Smith of the Department of Energy gave advice and guidance critical to the study.

Approved for:

SOLAK ENERGY RESEARCH INSTITUTE

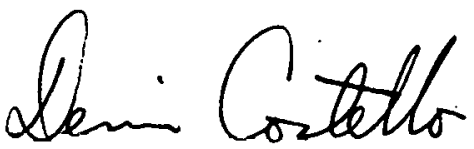

Dennis Castello, Chief

Economic Analysis Branch 


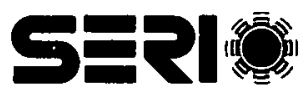




\section{SUMMARY}

\section{OBJECTIVE AND BACKGROUND}

The objective of this study is to provide the Department of Energy with information helpful in designing future photovoltaic procurem ent programs. The study focuses on the effects of alternative procurement strategies on current and potential suppliers of photovoltaic modules and systems. Several photovoltaic procurements using federal funds have already been initiated, including the Federal Photovoltaic Utilization Program, which installs photovoltaic systems in federal facilities, and the DOE photovoltaic system test and applications program, which supports photovoltaic system experiments in the private sector. During the next few years, increases in federal procurements of photovoltaic systems are anticipated. A number of procurement strategies have already been proposed: $f(\alpha$ example, purchasing large quantities of photovoltaic systems under fixed-price contracts that specify progressively lower prices. Current DOE plans state that a multiyear program to purchase photovol taic systems for a variety of applications will begin in FY81. There has been little analysis of what a fixed-price procurement program would accomplish and, further, there has not yet been an examination of the effect of alternative procurement strategies on the photovoltaic industry. This report is an at tempt to begin to fill that gap.

\section{APPROACH}

To place photovoltaic procurements in perspective with other federal procurements, a histarical review was conducted. Particular attention was directed towards Department of Defense (DOD) procurements of semiconductor devices in the $1950 \mathrm{~s}$ and 1960s, because these procurements have of ten been cited as exemplifying what similar procurements could do for photovoltaics. Next, a series of interviews was conducted with thir teen companies currently producing photovol taic modules or conducting research and development in photovoltaics to explore the effects of alternative federal procurement strategies on the photovol taic industry. Strategies examined were small, cost-based purchases of complete photovoltaic systems from a large number suppliers; large, multiyear purchases of photovoltaic modules from a few suppliers under fixed-price contracts with declining price schedules; suppart for photovoltaic production facilities; and procurements of prototypes of innovative module concepts.

\section{CONCLUSTONS}

Significant Differences Exist between Barly Government Semiconireter Procurements and Photovoltaic Procurements Currently Being Considered

Substantial evidence exists to conclude that procurements were an effective means of encouraging semiconductor technological advances. A distinguishing characteristic of Department of Defense purchases of semiconductors was their emphasis on performance, reliability, and design -requirem ents. DOD was willing to purchase innovative products at premium prices. When lower prices become the objective of government photovoltaic 
procurements, the stimulus provided by an early federal market that is more profitable and accessible than private markets is reduced. The introduction of cost reduction as the major objective of photovoltaic procurements is likely to change the influences that these procurements have on industry development.

Small, Cost-Based Procurements Encourage Industry Diversity and Provide Performance Information

Small contracts can encourage many different companies to gain experience with a wide variety of photovol taic systems. These systems can provide valuable information to both suppliers and potential users on the performance of photovoltaic systems. Because of their small size and short duration, contracts for single systems are unlikely to stimulate industry investments that could result in lower modulo production costs. However, experience gained in the design and installation may indirectly aid in reducing system costs.

Fixed-Price Contraets Could Stimulate Short-Term Cost Reductions but May Change Industry Strueture

Large, multiyear, fixed-price contracts for photovoltaic modules that specify progressively lower module prices could reduce the market uncertainties faced by participating companies and stimulate investments leading to short-term cost reductions. Only a few companies are likely to bid on contracts tied to the Department of Energy photovoltaic price goals. Companies with access to substantial financial resources appear to be in the best position to bid on contracts that require commitments to prices below those that have been attained to date. Companies receiving large, multiyear contracts might achieve a dominant position in the photovoltaic industry, but this position could be challenged by companies making research advances.

Prodinetion Pecilily Subsidies and Innovative Produet Procurements Are Attractive to Some Companies

Production facility subsidies are attractive to some firms because they provide direct support for improved production techniques. Several companies, however, believe that facility subsidies are not necessary because firms with viable new concepts should be capable of obtaining private capital. Innovative procurements of new module concepts with potential for lower cost are also attractive to several companies but will be difficult to implement because of prohlems in evaluating the potentiul for cost reductions.

\section{Procurement Strategies Should Be Matched with Objeetives}

Before an effective photovoltaic procurement program can be designed, it will be necessary to clearly state the objecties of the program. For example, industry diversity and provision of information on photovoltaic applications could be provided through small, short-term, cost-based procurements. Industry investments in cost-reducing production techniques, however, could be achieved through larger, multiyear contracts. Once the objectives of a procurement program have been defined, several details of procurement design should be carefully considered. The duration of a procurement contract, the evaluation criteria used in making awards, and the size of contracts are some of the details that are critical to the design and implementation of an effective procurem ent program. 


\section{Effeets of Photovoltaic Procuremerts on Potential Purchasers Need to Be Examined}

This study has been confined to consideration of the eff ects of government procurements on the photovoltaic supply industry. The response of potential users is as important to developing a federal photovoltaic procurement strategy as the supply-side issues. User cost sharing as well as other mechanisms for ensuring adequate involvement of potential users should be examined.

Clear Statememt of Anticipated Federal Photovoltaic Program Procurements Would Magnify Impaets

For the government to favorably influence industrial investment and cost reduction plans, a consistent and predic table program to purchase photovoltaic systems has to be outlined. Programs that change frequently reduce the credibility of future programs, add to market uncer tainty, and have $a$ de trim ental eff ect on industry planning. 


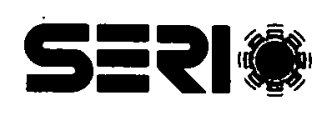




\section{TABLE OF CONTENTS}

Page

1.0 Introduction $\ldots \ldots \ldots \ldots \ldots \ldots \ldots \ldots \ldots \ldots \ldots \ldots \ldots \ldots \ldots \ldots \ldots \ldots \ldots \ldots \ldots$

1.1 Background..................................... 1

1.2 Purposes of Report and Report Organization $\ldots \ldots \ldots \ldots \ldots \ldots \ldots \ldots \ldots$

2.0 Historical Review of Federal Procurement Policies and Programs ......... 5

2.1 An Overview of Federal Procurement ..................... 5

2.1.1 Historical Perspective ......................... 6

2.1.2 Function of Procurement ........................ 8

2.1.3 Federal Assistance ............................ 9

2.1.4 Organizational Roles and Technology Development .......... 10

2.1.5 Organization of Federal Procurement .................. 11

2.1.6 New Procurement Policy Directions ..................... 12

2.2 DOD Procurement Policies ............................. 14

2.2.1 Types of Contracts ................................. 14

2.2.2 Allocation of Risk, Technological Uncertainty, and

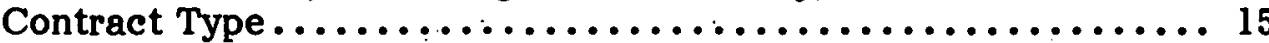

2.2.3 Contract Performance ........................... 17

2.3 DOD/NASA Purchases and Their Influences on the Semiconductor

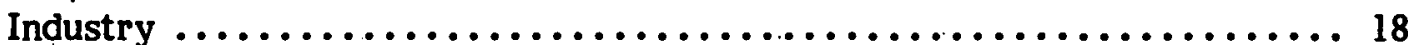

2.3.1 Data on DOD/NASA Purchases ...................... 19

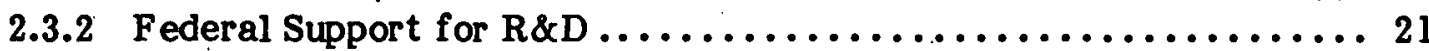

2.3.3 Federal Program Influences........................ 23

2.3.3.1 Major Semiconductor Innovations and Federal

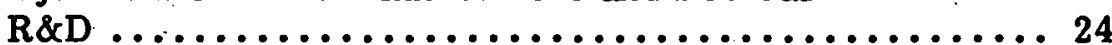

2.3.3.2 The Influence of Federal Procurements............ 25

2.3.3.3 Premium Prices: Emphasis on Reliability and Performance...................... 26

2.3.3.4 Support for New Firms ...................... 27

2.3.3.5 Demonstration Effects of Federal Purchases ........... 28

2.3.3.6 Procurement as an Inducement for Private $R \& D$........ 28

2.3.3.7 Nature of Procurement Contracts ................ 29

2.4 Conclusions of Review Relevant to Photovoltaic Procurements . . . . . . . . 29

2.4.1 Fixed Price Contracts. Are Typically Used for Well-Defined

Products and Production Processes that Have Long

Histories of Commercial Production .................. 30

2.4.2 Early DOD Purchases of Semiconductor Products Emphasized

Performance, Reliability, and Design Requirements;

Innovative Products Were Purchased at Premium. Prices ....... 30

2.4.3. Early DOD Semiconductor Purchases Stimulated Industry

Competition; Yet Photovoltaic Purchases Will Need to

Be Concentrated in a Few Firms to Encourage Investments

in New Production Techniques .......................

2.4.4 Successful Commercial Products Have Resulted from

Programs Which Have Made Convincing Demonstrations of

the Usefulness of the Product....................... 31

2.4.5 Little Precedent Exists for Federal Purchases in Excess

of Needs ....................................... 


\section{TABLE OF CONTENTS (continued)}

3.0 Methodology for Assessment of Industry Responses to Alternative Procurement Strategies

3.1 Procurement Strategies for Discussion and Interview

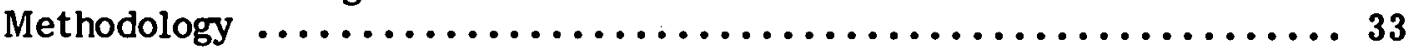

3.2 Companies Participating in the Study $\ldots \ldots \ldots \ldots \ldots \ldots \ldots \ldots \ldots \ldots \ldots$

4.0 Company Responses to Alternative Prosurement Strategies ............ 41

4.1 Industry Responses to Strategy l: No Fixed-Price, Moderate

Budget .......................................4 4

4.2 Induatry Responses tu S Lrulegy 2: Fixeô-Price, Moderate

Budget ...................................... 45

4.3 Industry Responses to Strategy 3: Fixed-Price, Aggressive

Budget ..................................... 51

4.4 Industry Responses to Strategy 4: Experimental Production

Facility Subsidies and Fixed-Price Buys .................. 52

4.5 Industry Responses to Strategy 5: Innovative Product

Procurement .................................. 54

5.0 Comparison and Discussion of Interview Results $\ldots \ldots \ldots \ldots \ldots \ldots \ldots \ldots \ldots$

5.1 Comparison of Results $\ldots \ldots \ldots \ldots \ldots \ldots \ldots \ldots \ldots \ldots \ldots \ldots \ldots \ldots$

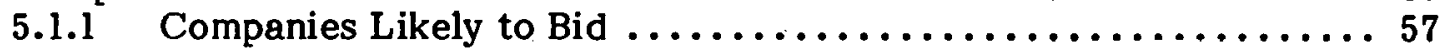

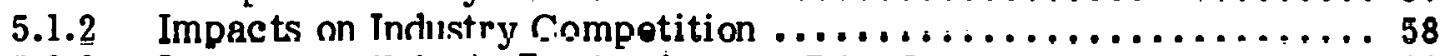

5.1.3 Impacts on Private Production and $R \& D$ Investments . . . . . . . 60

5.1.4 Impacts on System and Module Costs and Prices ............61

5.2 Other Issues Raised in Interviews ...................... 61

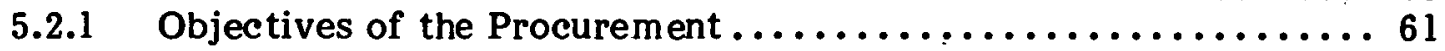

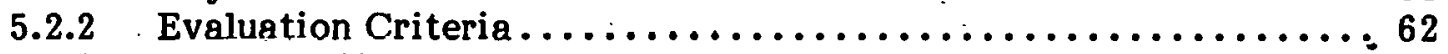

5.2 .3 Contract Size............................. 64

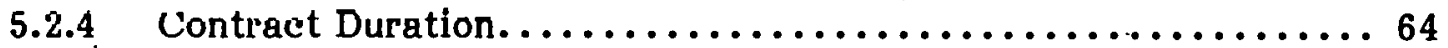

5.2.5 Escalation and Exit Clauses.....................

5.2.6 Module vs. System Purchases ...................... 66

5.2.7 Program Timing and Technologies Favored............... $\ldots$ G

5.2 .8 Response Time for Proposal Submission ................ 67

5.2.9 Future Supplies and Prices of Polysilicon ............. 67

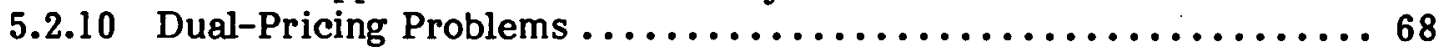

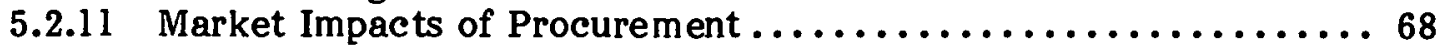

5.2.12 Sales After Procurement Ends ................... 68

6.0 Conclusions $\ldots \ldots \ldots \ldots \ldots \ldots \ldots \ldots \ldots \ldots \ldots \ldots \ldots \ldots \ldots \ldots \ldots \ldots \ldots \ldots \ldots \ldots \ldots$

6.1 Significant Differences Exist between Early Semiconductor

Procurements and Photovoltaic Procurements Currently

Being Considered ................................. 69

6.2 Small, Cost-Based Procurements Encourage Industry Diversity

and Provide Performance Information. .................. 70 


\section{TABLE OF CONTENTS (concluded)}

6.3 Fixed Price Contracts Could Stimulate Short-Term Cost

Reductions but May Change Industry Structure ............... 70

6.4 Production Facility Subsidies and Innovative Product

Procurements Are Attractive to Some Companies ............... 71

6.5 Procurement Strategies Should Be Matched with Objectives .......... 72

6.6 Effects of Photovoltaic Procurements on Potential

Purchasers Need to Be Examined........................ 72

6.7 Clear Statement of Anticipated Federal Photovoltaic

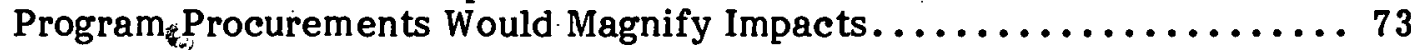

7.0 References....................................... 75

Appendix A. Profile of Photovoltaic Industry Today $\ldots \ldots \ldots \ldots \ldots \ldots \ldots \ldots$

A.1 Historical Trends in Module Sales and Prices ............. 79

A.2 Photovoltaic Price Trends ......................... 80

A.3 Companies Manufacturing Today .................. 82

A.4 Marketing and Distribution ................... 85

A.5 Research and Development Performers.............. 86

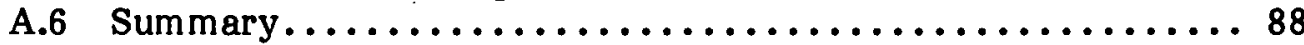

A.7 References.............................. 89 


\section{SER눈}

xii 


\section{LIST OF TABLES}

$\underline{\text { Page }}$

2-1 Sources of Procurement Policy ............................11

$2-2$ Characteristics of Contract Types .............................. 15

2-3 Procurement of Major Hardware by Type of Contract, Fiscal

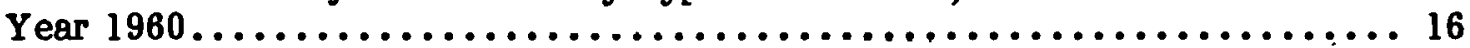

2-4 U.S. Production of Semiconductors for Defense Requirements,

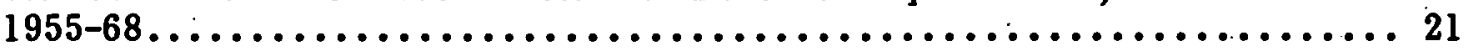

2-5 U.S. Integrated-Circuit Production and Prices, and the Importance of

the Defense Market, 1962-68 .............................. 21

2-6 Government and Industry R\&D Funds for Electronic Components and

Communication Equipment (SIC Codes 366, 367, 481), 1957-68 ........ 22

2-7 U.S. Government Funds Allocated Directly to Firms for Semiconductor

Research and Development and for Production Refinement Projects,

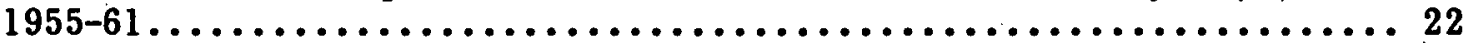

2-8 Direct and Indirect Government Expenditures and Private R\&D

Expenditures in Semiconductor Industry $\ldots \ldots \ldots \ldots \ldots \ldots \ldots \ldots \ldots \ldots \ldots . \ldots 23$

3-1 Strategy 1: No Fixed-Price, Moderate Budget ................... 34

3-2 Strategy 2: Fixed-Price, Moderate Budget ....................... 35

3-3 Strategy 3: Fixed-Price, Aggressive Budget..................... 36

3-4 Strategy 4: Experimental Production Facilities and Fixed-Price

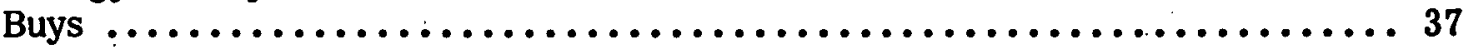

3-5 Strategy 5: Innovative Product Procurement................... 37

3-6 Companies and Individuals Participating in Study ................ 39

4-1 Responses to Strategy 1: No Fixed-Price, Moderate Budget ............43

4-2 Responses to Strategy 2: Fixed-Price, Moderate Budget ..............46

4-3 Responses to Strategy 3: Fixed-Price, Aggressive Budget .............. 52

4-4 Responses to Strategy 4: Experimental Production Facility Subsidies

and Fixed-Price Buys ................................ 53

4-5 Responses to Strategy 5: Innovative Product Procurement .............55

5-1 Companies Likely to Bid on Alternative Procurement Strategies ..........57

5-2 Impacts of Alternative Strategies on Industry Competition . . . . . . . . . . 59

5-3 Impacts of Alternative Procurement Strategies on Private

Production and $R \& D$ Investments . . . . . . . . . . . . . . . . . . . 60

5-4 Impacts of Alternative Procurement Strategies on System

and Module Costs and Prices..............................61

A-1 1976 Photovoltaic Module Sales ........................... 80

A-2 Results of SERI Telephone Survey on Prices of Photovoltaic Modules-

June $1,1978 \ldots \ldots \ldots \ldots \ldots \ldots \ldots \ldots \ldots \ldots \ldots \ldots \ldots \ldots \ldots \ldots \ldots \ldots \ldots \ldots \ldots \ldots$

A-3 Characteristics of Companies Currently Producing Photovoltaic

Modules .......................................... 83

A-4 Estimated Investment and Production Rates of Firms Producing and

Marketing Single-Crystal Silicon Photovoltaics in $1978 \ldots \ldots \ldots \ldots \ldots \ldots \ldots 84$

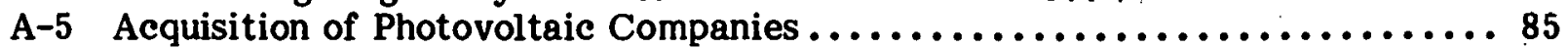

A-6 R\&D Activities of Companies Exclusively Performing R\&D . . . . . . . . . . 87 
SEPI䊪 


\section{LIST OF FIGURES}

$\underline{\text { Page }}$

2-1 Annual Sales in Basic Electronies Markets . . . . . . . . . . . . . . . 19

2-2 United States Components Industry $\ldots \ldots \ldots \ldots \ldots \ldots \ldots \ldots \ldots \ldots \ldots \ldots$

4-1 Categorization of Company Responses $\ldots \ldots \ldots \ldots \ldots \ldots \ldots \ldots \ldots \ldots \ldots \ldots$

A-1 Estimate of Photovoltaic Industry: Annual Sources and Uses of Funds,

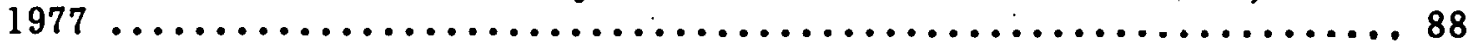


SERㄴ. 


\section{SECTION 1.0}

\section{INTRODUCTION}

This report is the result of a study of photovoltaic procurement strategies conducted at SERI. The study focuses on the effects of alternative photovoltaic procurement strategies on suppliers. Strategies aimed at having the greatest positive influence on potential users are not examined. A more extensive assessment of procurement strategies, currently being conducted by the Photovoltaics Lead Center at the Jet Propulsion Laboratory for the Department of Energy (DOE) Photovoltaics Program, is expected to help define future DOE photovoltaic procurements by considering both supply and user response.

\section{I.1 BACKGROUND}

Since late in 1977, there has been an interest within the DOE Photovoltaics Program to increase federal purchases of photovoltaic arrays and system hardware. Proposals for photovoltaic procurements have taken several different forms and have been intended to achieve a variety of objectives.

In 1977 , a $\$ 380$ million, eight-year procurement was proposed [1]. By subsidizing private purchases of photovoltaic systems, this program was postulated to induce industry capitalization that would result in lower photovoltaic array and system prices. Lower prices would then stimulate increased sales, allowing further improvements in production processes and still lower costs. The primary purpose of this program (termed the marketpull strategy) was to facilitate cost and price reductions of photovoltaic systems.

A detailed study of the expected impact of the program was conducted by SERI [2]. This study found that the pronnsed initiative is not likely to be an effective means of stimulating photovoltaic system cost reductions. The costs of the prograin were estimated to exceed the benefits resulting from lower system prices.

During the summer of 1978 , an alternative approach to photovoltaic procurements was suggested by some companies in the photovoltaic industry [3]. This approach has been termed a fixed-price buy. The concept is to purchase a substantial quantity of photovoltaic arrays from a small number of selected suppliers (perhaps two to five) at prices below current prices. The purchase contracts would last three to five years and specify a declining price schedule and increasing quantity of module deliveries on a fixed-price basis.

The rationale behind the fixed-price concept is to concentrate federal purchases in a few companies and thereby provide these companies with a significant guaranteed market. Elimination of market uncertainty would enable companies to invest in improved production technologies that promise lower costs. These companies would then be capable of supplying arrays to the federal government and private purchasers at lower prices than are offered currently. 
Current DOE program plans state that a multiyear strategy for the purchase of photovoltaic systems will be initiated in FY81 and continue through FY85 [4]. This program is expected to be the core of the DOE market development effort for photovoltaics. The program will strive to support the photovoltaic industry and help establish the supplier infrastructure needed to deliver and construct photovoltaic systems for a variety of applications. Discussions with the photovoltaic industry and other program participants are now under way to further define the details of this program. The FY81 budget request far the program is $\$ 30$ million.

Three recent laws have mandated increased federal purchases of photovoltaic systems. The Department of Energy Act of 1978 made approximately $\$ 12$ million available for purchase of photovoltalc systems for use in federal facilities [5]. These funds were called $f o r$ in what is frequently referred to as the Tsongas Amendment. In the National Energy Conservation Pollcy Act of 1978, a Federal Photovoltaic Utilization Program (FPUP) was mandated to take place from FY79-81 [6]. FPUP is a program of photovoltaic purchases for use in federal facilities. The FPUP authorization is at $\$ 98 \mathrm{mil}-$ lion. In FY79 and FY80, a total of $\$ 25$ million in FPUP funds have been appropriated. Together, FPUP and the DOE Act add up to $\$ 37$ million to be used for the purchase of pho tovol taic systems in federal facilities in FY79 and FY80.

The Solar Photovoltaics Research, Development, and Demonstration Act of 1978 establishes a 10-year $\$ 1.5$ billion federal commitment to photovoltaics [7]. While specific purchase quantities, purchasing procedures, and schedules are left to the discretion of DOE, the act calls for a major federal effort in photovol taic demonstrations. Continued research and development are the other components of the KD\&D Act programs.

Beyond the SERI Photovoltaic Venture Analysis [2], little effort has been devoted to examining the impacts of federal purchasing prograns on the industrial and market development of photovol taics. The Jot Propulsion Luboratory has estimated the costs of one fixed-price procurement program, but this analysis does not estimate the eff ects of this program [8]. While many purchasing programs have been proposed and one is presently being implemented, a clear statement of the objectives and expected results of federal purchasing programs has not been issued by DOE [9]. Therc also is insufflcient information on the implications for the photovoltaic industry of different approaches to federal procurement. Yet, it is olear that insiussingly lárge federal purchases of photovoltaic hardware will be pursued.

\subsection{PURPOSES OF REPORT AND REPORT ORGANIZATION}

The primary purpose of this report is to give DOE information to help develop an effective procurement strategy. This is accomplished by examining the responses to alternative photovoltaic procurement programs of a representative group of companies active in photovoltaics today. To date, only a few companies have formally expressed their opinion on the fixed-price procurem ent proposals. Responses to the fixed-price buy are emphasized in this study. However, a number of other approaches to photovoltaic procurements, some of which were suggested by a historical review, are also examined. Section 3.0 describes the methodology used to solicit company responses to alternative 
programs. Informal interviews were held with 13 companies, including companies currently manufacturing photovoltaic modules and companies that are potential producers but whose activities are limited presently to photovoltaic research and development (R\&D). These companies were asked to describe the possible impacts of five al ternative procurement strategies on their own plans and on the photovoltaic industry as a whole. Section 4.0 summarizes their responses.

A secondary purpose is to orient photovoltaic procurements within the context of procurements made by other federal agencies. Of particular interest are procurements intended to stimulate technological advances, such as those made by the Department of Defense (DOD). Section 2.0 examines historical federal procurement policies and programs, with emphasis on DOD policies and procurements of semiconductor devices. This section also considers the implications of other federal procurements for photovol taic procurement programs.

In Section 5.0, interview results are compared and discussed, and several issues critical to the design of an eff ective procurement program are raised. Section 6.0 presents the major conclusions resulting both from the literature review and the company interviews.

This study is not the only step required to derive a photovoltaic procurement strategy. The discussions contained in this report are primarily at a conceptual level and deal with basic strategies and tactics. Additional work is required to translate these strategies and tac tics into contractual instruments. The study only focuses on the response of suppliers to photovoltaic procurements. Equal attention should be given to how potential buyers will be aff ected by diff erent procure ment progra ms.

Any report that relies on informal interviews for information is subject to errors of interpretation. The intention here is not to present a conclusive view of what different procurement programs will and will not do. Rather, it is to identify issues that must be considered in making choices concerning program strategies and tactics, and to speculate on what the results of al ternative strategies and tactics may be.

This repart does not attempt to examine the costs and benefits of specific procurement programs or to compare the costs and benefits of federal procurements with other types of federal programs: for example, federal support of photovoltaic R\&D. It is assumed that federal procurements of photovol taic systems will be made and that procurements will become an important element of DOE photovoltaic expenditures in future years. The focus is on specific procurement strategies and tactics and how they can facilitate the development of the photovoltaic industry. 


\section{SEPI亳}




\section{SECTION 2.0}

\section{HISTORICAL REVIEW OF FEDERAL PROCUREMENT POLICIES AND PROGRAMS}

This section reviews the historical uses of federal procurements to achieve technological objectives of specific federal agencies. The procurement policies and practices of the Department of Defense (DOD) are the focus of this review. The impacts of DOD procurements on the development of new commercial products in the semiconductor industry are also reviewed. This information is intended to place photovoltaic procurement programs in the context of other government purchasing activities. Implications of past federal procurement experiences are drawn for the design of photovoltaic procurement proposals, particularly the fixed-price buy concept.

The review contained here is rather extensive; it attempts to carefully derive information relevant to photovoltaics from historical experience. Readers who would prefer to learn the conclusions of this review, rather than follow their derivation, are urged to skip to Section 2.4.

\subsection{AN OVERVIEW OF FEDERAL PROCUREMENT}

In 1977, the federal government spent more than $\$ 70$ billion for the purchase of systems, goods, and services [10, p. l]. On the average, approximately $2 \%$ of the sales of all U.S. commercial products are to the federal government $\mathrm{y}_{\mathrm{f}}$ some markets, the purchasing power of the government is much larger. For example, federal purchases comprise $28.2 \%$ of the transportation equipment market and $14 \%$ of the market for electrical machinery and supplies [11, Summary, p. 69]. In these markets, the federal government can be an influential buyer. For major military systems and several major civilian systems as well, the federal government is the only consumer; the existence of those companies producing defense systems is contingent on future government demand and budgets [12].

Government procurements are a significant force in the U.S. economy in general and in selected markets in particular. The magnitude of government purchases gives them an impact on the national economy beyond the direct impacts of satisfying government needs. As described in the Report of the Commission on Government Procurement (hereafter referred to as the Commission Report), "Federal procurement plays a. catalytic and pacing role in bringing Government-developed standards and products into practical commercial use" [11, Vol. 1, p. 3]. Federal procurements have been used also as a vehicle for achieving social and economic objectives, such as providing equal employment opportunities and improving working conditions.

This section begins with a historical discussion of the use of federal procurements and the federal regulations governing their use. The functions of federal procurements are summarized and a distinction between federal procurement and federal assistance is made. The organization of the procurement process is described. Finally, current policy incentives being implemented are outlined. 


\subsubsection{Historical Perspective}

The Commission Report contains a historical description of the development of the procurement process [11, Vol. 1, pp. 163-184]. Highlights of that description are presented here to indicate how current procurement procedures have evolved, particularly as they affect procurements of research and development or the products of research and development.

The federal government has faced the problem of organizing government purchases since the Revolutionary War. The process of federal procurement has grown increasingly complex; the first law related to procurement was passed in 1792, and today over 4,000 statutes affect the procurement process. This growth in procurement regulations reflects the huge increases in federal expenditures and the complexity of current procurement efforts and objectives.

Initially, following the dictates of Alexander Hamilton, procurement functions were centralized in the Department of Treasury. But as federal purchases grew, lindididual agencies became accustomed to obtaining needed supplies through their own budgets. The growing magnitude of federal purchases in the 1840 s led to mandatory advertising of federal procurements to allow unbiased access to the federal market. Purchases during this period were made exclusively on the basis of sealed bids, with low cost as the award criterion.

In 1893, a joint Senate and House commission reviewed federal procurement practices and found that there was little standardization between the purchasing habits of various agencies. In 1905, a General Supply Committee with a General Schedule of Supplies was established. Federal agencies purchased supplies from the General Supply Committee.

World War I brought a rapid increase in the rate of federal purchases and indicated the dominance of defense-related purchases that was to beculle mure evident in later years. Cost-type contracts were the common contractual mechanism used during the war. Even cost-plus-a-percentage-of-cost contracts were used, but these were outlawed soon after the war.

The General Accounting Office and the Bureau of Budget were created in the post World War I period. Both of these agencies began to play a monitoring and oversight role in the military procurements of the War and Navy Departments and civilian procurements, which were becoming more centralized in the Department of Treasury. The fluctuations in government demand that occurred between the war and the post-war period also demonstrated the problems caused by these rapidly changing purchase rates.

Prior to 1916, the government bought a total of 59 airplanes. During the 21 months of the war, 9,742 planes and 14,765 airplane engines were purchased. The decline in pirchases at the end of the war brought chaos to the aviation industry. The importance of maintaining a healthy aviation industry was recognized by the Congress in the Air Corps Act of 1926. It called for the purchase of 1,800 planes for the military over a five-year period. Procurement was shown to be a tool both for purchasing equipment at the time it was needed and a tool for ensuring preparedness for later conflicts. 
During World War I, cost-based contracts were again used, in contrast to the use of fixed-price contracts, which had been typical of previous peacetime purchases. The shift back to fixed price took place after the war, but some exceptions were made. In the aircraft industry, standardization of design and production had not been achieved yet to the degree needed for using the fixed-price approach. Instead, design competitions were instituted, and the government was allowed the freedom to award contracts that were most desirable from the government perspective.

The Depression brought about the first substantial efforts to use procurement to promote social and economic goals. Minimum wages were required under all federal contracts. Procurement was also used to stimulate improvement in working conditions, employ the handicapped, as well as promote other objectives that legislative and executive orders alone were unable to accomplish.

During World War II, negotiated contracts became a common mechanism for fulfilling defense needs. Negotiated contracts became authorized for defense needs in 1947. In the same year, negotiated contracts were approved for use by all federal agencies.

The General Services Administration was established in 1949 and given authority over the procurement policies of all federal agencies; with the exception of the Department of Defense. The trend in the 1950s was toward simplification of the procurement process. $\mathrm{DOD}$; as the major federal spender, took the lead in initiating and revising procurement policies. Changes in the Armed Services Procurement Regulations (ASPR) led to similar changes in Federal Purchasing Regulations (FPR). In the 1960s, a national supply system was set up to purchase common-use items for DOD and all other federal agencies.

A major change in the procurement environment accompanied the increase in sophistication and complexity of technologies in the 1950s and 1960s. As stated in the Commission Report:

While the Government's needs for commercial products grew apace with its size, it was the development of procurement programs for military and aerospace systems which required new techniques and complex contractual and organizational arrangements on an unprecedented scale [11, Vol. 1, p. 177].

The increased need for research and development and the acquisitions of major systems in the 1950s resulted in greater use of negotiated cost contracts. But the pattern of tremendous growth in the cost of major systems and the lack of effective cost controls in cost-type contracting brought these contracting procedures into disfavor. The $1960 \mathrm{~s}$ saw a movement toward shifting more of the risks of cost overruns to the private sector through the use of incentive and fixed-price contracts. There also was a movement toward more advertising and competition.

The need for industrial preparedness for defense needs, which was recognized initially through support of the aviation industry in the 1920s, was acknowledged on a much larger scale in the 1950s and 1960s. Under the old arsenal system, military equipment was bought and stored to maintain U.S. defense preparedness. But as defense technology became more sophisticated and dynamic, having adequate quantities of equipment was 
not sufficient to ensure a strong national defense. More important than numbers was having the most technologically advanced equipment. Thus, military needs could no longer be met by occasional purchases of hardware. It became essential to continually advance the state of military technology and replace old military systems. Rapid changes in technology made the arsenal system obsolete, and created the need for a "permanent defense industry." High uncertainties associated with major systems development and the size of investments needed to develop these systems caused federal assumption of many of the risks of development and production through cost-type contracts and, in some instances, federal provision of production capital.

The cost overruns of the 1950s, in addition to leading to efforts to allocate more risks to contract performers in the 1960s, have also encouraged a more sequential and competitive approach to new weapon systems development in the 1970s. In the 1950s and 1960s, many major systems were pushed from $R \& D$ to production under a single contract with few checkpoints along the way to explore alternative designs. Commitments to production and to a single design were premature. The tendency today is to rely more on the competitive development of designs and to enter production only after technical and financial uncertainties have been resolved. Today's procurèment establishment is also once again moving more toward centralization with the creation of the Office of Federal Procurement Policy in 1974. Current trends in procurement policies and major procurement directives related to technological advance are discussed below.

\subsubsection{Function of Procurement}

The Commission Report articulates the function of procurement of commercial products as follows: "The basic purpose of the procurement system is to provide the user with required goods, services, and facilities in the most effective and economical way pos-

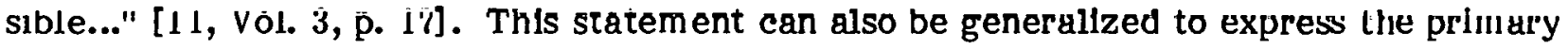
purpose of the acquisitions of major systems for defense purposes. In the defense area, procurement has expanded beyond the intermittent purchase of present state-of-the-art systems. The need for rapid technological advance and sophistication of new weapon systems has resulted in the essentially permanent support of a defense industry to push technological accomplishments and maintain industrial preparedness.

Definition of national needs is subject to broad interpretation. Procurement is the approach used to conduct the entire space program. In this case, national needs encompassed the development of the technical expertise to explore space. Like defense procurements, the federal government was the single buyer in the space exploration market. Procurement resulted in the development and production of systems that were used by the government to satisfy stated national objectives.

Other functions of federal procurement have been cited in the previous section. These include social and economical objectives such as occupational safety and protection of selected groups of individuals or businesses. Today, as described in the discussion below of new procurement policy directives, procurement is being used to stimulate industrial innovation in product design. 
These functions of federal procurement must be categorized as secondary to the primary purpose of fulfilling federal needs. Once a need has been identified, the specific procurement mechanism can be used to try to achieve a variety of secondary objectives. If no need exists, there is little evidence to suggest that federal purchases have been made to realize only these secondary objectives.

\subsubsection{Federal Assistance}

Federal expenditures for research and development related to technologies for use in civilian applications have increased from less than $\$ 1$ billion in 1953 to nearly $\$ 14$ billion in 1978 [13, p. 19]. This rapid increase in expenditures represents expanded federal involvement in helping solve private sector problems. How do these federal expenditures relate to the federal procurements discussed above?

This question has only recently been addressed formally. The Federal Grant and Cooperative Agreement Act of 1977 distinguishes between assistance relationships and procurement relationships. The functions of procurement relationships have been defined above. As stated in an Office of Technology Assessment analysis of the distinction between procurement and civilian $R \& D$, "The basic need to acquire goods and services at fair value for the government's sake has led to a set of highly developed procedures" [13, p. 8].

The report continues:

Assistance on the other hand, has neither a precise, well defined meaning nor uniform, widely understood administrative practices associated with it. The term assistance generally is taken to connote the provision of money, services, or property to a non-federal party to accomplish a broad public purpose [13, p. 8].

The important difference between procurement and assistance is one of objectives. Procurement is used to obtain goods and services for use by the federal government. Expenditures for assistance are intended to promote a socially desirable objective. In most cases, the ultimate consumer of the products of assistance expenditures is not the federal government, but private consumers and institutions. The Grant and Cooperative Agreement Act suggests that different purchasing mechanisms be used for procurement and assistance programs. This act states that various types of contracts are applicable to procurements, while grants or cooperative agreements are more appropriate for assistance programs.

Civilian technology programs have been confined primarily to research, development, and demonstration. These programs have been pursued using both contracts and grants. Regardless of funding mechanisms, these programs are federal assistance programs. Assistance programs are essentially an extension of federal needs and, to date, have used the same purchasing techniques that have been used in federal procurements. 


\subsubsection{Organizational Roles and Technology Development}

To understand the motivation for use of federal procurement to stimulate civilian technology development and application, it is informative to look at the roles typically performed by the federal government and the private sector in advancing new technologies [14, pp. II-4-I-9]. When an industrial firm introduces a new technology or product, it provides its own $R \& D$ funds to develop the product, performs its own $R \& D$, and is the producer of the new product. The firm attempts to market the product to potential users.

In the case of government acquisition of new weapon technology, DOD funds a private company to perform the $R \& D$ and the same or a different company to produce the system. DOD is the user or consumer of the technology.

When DOE attempts to develop a new energy technology through various assistance programs, it usually funds research and development to be perfor med by a private company, university, or government laboratory. For diffusion in to the private market to occur, a private company must be motivated to take the results of this $R \& D$ and apply them to the production of a new product. The company then markets the new product to potential users.

In the industrial case, the innovating company is the catalyst for success, subject to the positive response of prospective markets. In weapons development, the government, as both the source of $R \& D$ funds and the end user, has a major influence on project success. However, the ability of private companies to make the product is also essential. DOD procurement of the results of $R \& D$ efforts ensures that the technology will be implemented. The role of the government in the private $R \& D$ case is much weaker. Government involvement in private $R \& D$ is limited to the funding of $R \& D$ and support of programs that encourage private companies to produce the technology and users to adopt it.

The development of many new civilian technologies (e.g., photovoltaics) is being supported by the federal government. This federal assistance of civilian R\&D has expanded rapidly in the last 25 years. Federal support of civilian technology development has of ten gone beyond the support of $R \& D$. The governm ent, for example, has purchased new technologies in federal facilities. Federally supported demonstrations in private markets have also been initiated. These federal procurem ents provide industry and market experience with new technologies. The magnitude of these federal purchases, however, is usually limited. Industrial and market development remains the domain of private industry.

The power of DOD in stimulating both the development and production of new technologies through support of $R \& D$ and procurement of systems has been pointed to as an illustration of what could be accomplished through large federal purchases of the products of civilian $R \& D$. Federal assistance of civilian $R \& D$ is a well-established role for the federal government. Federal procurements have been used to encourage technological innovation. But the size of these procurements has been limited to needs within the federal government and to assistance objectives, such as funding of private demonstrations. There is little precedent for large federal purchases in excess of broadly defined needs to increase the influence of the federal government in the innovation 
process for civilian technologies. Attempts to close the loop between the funding of $R \& D$ and the purchase of the products of $R \& D$ represent a new application of federal procurement. The only precedents for this type of procurement approach are within DOD.

\subsubsection{Organization of Federal Procurement}

Before beginning to review DOD procurement procedures and experience, the organization of federal procurement policy development and implementation will be described briefly [11, Vol. 1, pp. 9-14]. Table 2-1 lists the various government organizations that play a role in the federal procurement process as described in the Commission Report. Since the completion of the Commission Report, its first recommendation-establishment of an Office of Federal Procurement Policy (OFPP) within the Office of Management and Budget-was realized in 1974 [15]. Table 2-1 indicates the roles played by each entity.

Table 2-1. SOURCES OF PROCUREMENT POLICY ${ }^{a}$

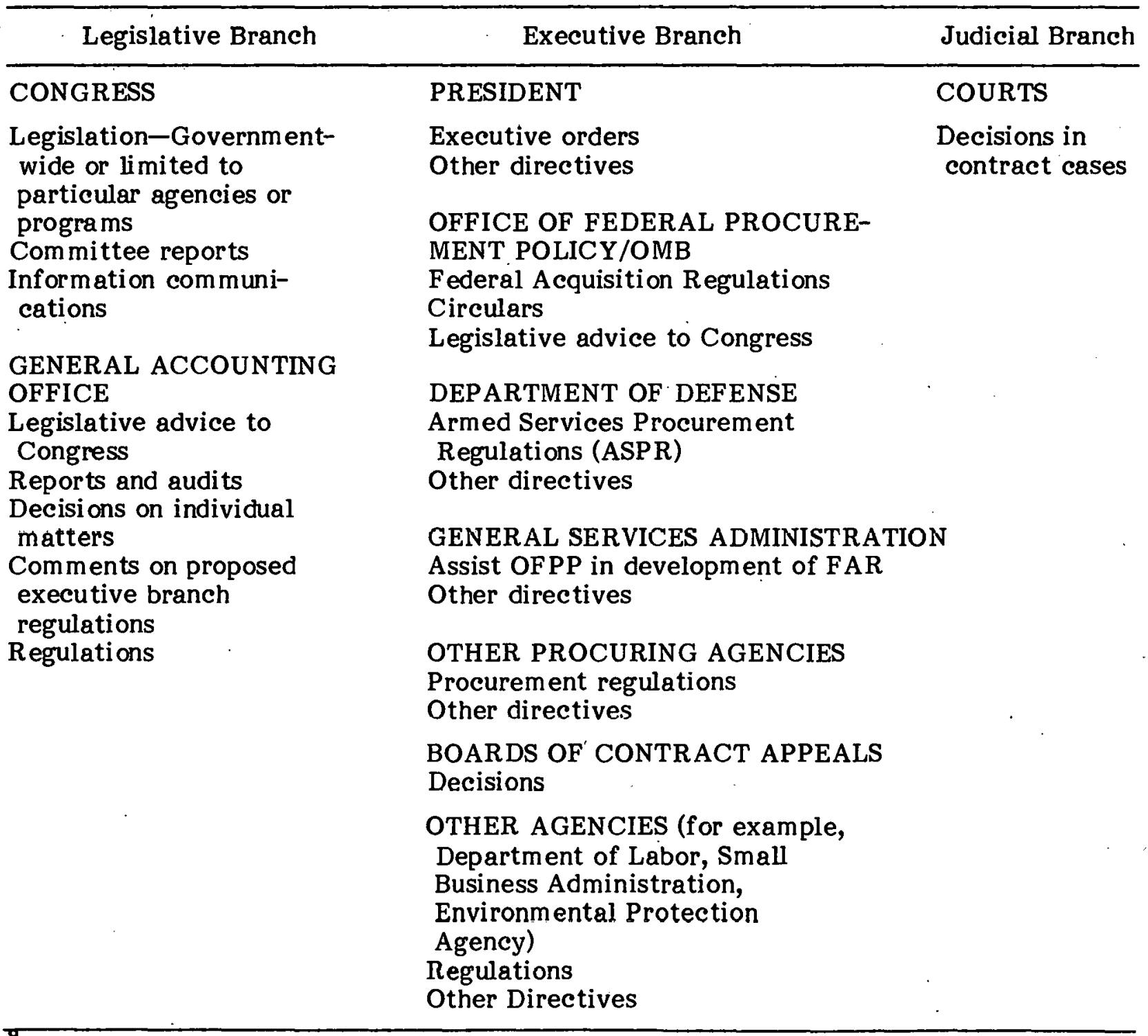

[11, Vol. 1, p. 10]. Updated to include responsibilities and Office of Federal Procurement Policy. 
The Legislative Branch establishes fundamental procurement policies by Congressional legislation and by the oversight activities of Congressional committees and the General Accounting Office. The Executive branch carries the responsibility for implementation of procurement policies. The Office of Federal Procurement Policy plays a key role in implementation by initiating and coordinating new policy directives as well as developing standardized procurement regulations to be used by all federal agencies. Other federal agencies have the responsibility for applying these regulations to their own programs. $\mathrm{DOD}$, because of its large share of federal expenditures, plays a leading role in the development of procedures for defense use and is responsible for formulation and enforcement of the Armed Services Procurement Regulations (ASPR). The General Services Administration has significant influence in the development and application of procurement policies for other agencies through its assistance to OFPP in establishing a new uniform set of Federal Acquisition Regulations that will replace the Federal Procurement Regulations. The Judicial Branch is responsible for interpretations of procurement regulations by settling lawsuits filed in federal courts.

\subsubsection{New Procurement Policy Directions}

Currently, a number of new federal procurement policies are being implemented by the OF PP [16]. Under direction of the Department of Commerce, a Domestic Policy Review is being conducted on industrial innovation. As part of this review, the relationship. between federal procurement policies and industrial innovation is being examined. An industrial advisory committee has recently recommended changes as a result of this review [17]. Other government entities, such as the Experimental Technology Incentives Program (ETIP) within the _Department of Commerce and the National Science Foundation, are experimenting with new ways to use procurement as a mechanism to stimulate technological change [18]. These activities are summarized here to suggest new directions in federal procurement policies for programs that relate to technological innovation.

OFPP's highest priority is the implementation of OMB circular A-109, concerning Major System Acquisition Policy. For all major systems development programs within DOD and other agencies, A-109 requires a formal mission-oriented structure to be developed before a program is initiated. A-109 also calls for use of multiple, competitive design approaches in the early stages of systems development. Competitive designs of major systems are to be maintained longer in the development cycle. The intention of this approach is to ensure sufficient investment in relatively inexpensive design innovations. Emphasis on design competition should reduce premature and costly commitments to the production of inferior system designs. These-modifications in major system acquisition policy are intended to provide consistent and stable expressions of government priority and increase design competition.

Procedures for acquisition of commercial products also are being reviewed by OFPP. When possible, the government will purchase off-the-shelf commercial items rather than products designed to meet government specifications. In the past, government specifications for some common use items (e.g., office furniture) have been so elaborate that suppliers have had to redesign their products to meet government specifications. Special 
product designs of ten result in higher costs. Only a few suppliers have been willing to redesign some products to meet government specifications. The elimination of unnecessary specifications for commercial products should reduce costs and stimulate greater competition between suppliers in the government market.

OFPP also is pursuing changes in $R \& D$ acquisition policies. Requiring a more formal statement of agency mission and improvements in cost-estimation procedures are two current areas of investigation.

Other OFPP activities include development of a Federal Procurement Data System to be housed in DOD and establishing a Federal Acquisition Institute with responsibility for educating procurement professionals and conducting research and analysis on procurement policies. An integrated National Supply System for government-wide acquisition is being planned by OF PP as well as a uniform set of Federal Acquisition Regulations for use by all agencies.

The Advisory Subcommittee on Procurement and Direct Support of Research and Development to the Domestic Policy Review of Industrial Innovation, in addition to supporting the current activities at the OFPP, recommended futher changes in procurement policy. For example, it suggested that the government stimulate innovation by providing an early market for innovative products. Often, commercial products are selected on the basis of lowest price. Yet, many other products could be less expensive on a life-cycle cost basis. This policy discourages innovation in commercial product design. Independent Research and Development (IR\&D) may currently be undertaken by DOD contractors at government expense so long as it is relevant to DOD needs, passes a technical review, and costs less than a prespecified cost ceiling. The subcommittee believes that such extensive controls of IR\&D discourages innovation and that the controls should be relaxed. Patent policies, which require that all patentable results of government-funded research remain in the public domain, reduce industry motivations to innovate and should be changed. The subcommittee also called for federal agencies to develop procurement proposals to be reviewed by OMB, which would stimulate industrial innovàtion.

The Experimental Technology Incentives Program works with federal agencies in the design and evaluation of experiments using procurement techniques that are thought to be incentives for product innovation. ETIP has cosponsored several efforts that emphasize techniques such as performance-based specifications and life-cycle costing.

The National Science Foundation has initiated a modest new program to encourage innovation in small businesses, called Small Business Innovation Applied to National Needs [18]. The program uses federal funds to support promising R\&D proposals by small companies. Bidding companies are encouraged to obtain commitments from venture capital companies for financing commercial application of the results of $R \& D$. The program offers small businesses access to federal financing for high-risk research and also helps these companies obtain access to private financing if they are successful. 


\subsection{DOD PROCUREMENT POLICIES}

This section examines the types of contracts used by DOD. Particular attention is given to the allocation of risk between the government and contractor embodied in different types of contracts and the applicability of contract types under varying extents of technological uncertainty. The experience with DOD contract performance and the structure of the DOD contracting and market are also considered.

\subsubsection{Types of Contracts}

There are two major types of contracts used by DOD: fixed-price and cost-based contracts. There are several variations within these two major categories.

A firm, fixed-price contract is a contract to deliver a product at a prespecifier price. Nearly all contracts between two private companies are made on a firm, fixed-price basis. Fixed-price contracts may contain a clause for price escalations and, then, are called fixed-price-with-escalation. These contracts are used to protect the supplier from increases in the prices of materials or components that could occur but are beyond the contractor's control [19, pp. 1-3].

Fixed-price contracts may include also a clause for contract redetermination and are called fixed-price-with-redetermination. Under this arrangement, the initial fixed-price terms of the contract are binding only for a limited period of time, after which new fixed-price terms are negotiated for following periods. This redetermination approach has been primarily used to account for future changes in prices, although retrospective price modifications also have been used occasionally [19, pp. 4-5].

A final variation of fixed-price contracts is the fixed-price incentive contract. Here, a target cost and a target contractor profit are specified which, added together, comprise the target price. A cost-sharing ratio between the government agency and the contractor is agreed to. If actual costs are below target, then the total savings are allocated between contract performer and the government acconring to the sharing formula. $\Lambda$ price ceiling is usually set. If the price goes above this ceiling, there is no profit to the contractor, and there will be a loss. Eighty percent of cost savings typically have been retained by the government, with the remaining $20 \%$ given to the successful contractor $[19$, pp. 5-6].

The most common type of cost-based contract is the cost-plus-a-fixed-fee. A cost for performance of the contract and a fee that is a percentage of cost is established when the contract is initiated. When the cost of the contract exceeds estimated cost, the contractor has technically completed the contract, even though he may have fallen short of the desired results. Usually when cost exceeds estimated cost, the contract is modified and the cost is adjusted upwards. The fee, however, is not changed to reflect increases in costs. It is also possible for contract extensions to be implemented via the issue of new contracts. In this case, the cost as well as the fee has been modified, and the contract resembles the cost-plus-percentage-of-cost contract that was made illegal after World War II [19, pp. 7-9]. 
The other major type of cost-based contract is the cost-plus-incentive-fee. An allowable cost, target fee, and formula for fee adjustments are specified at the beginning of the contract. If actual cost is below estimated cost, then the savings are split between the government and the contractor according to the fee adjustment formula. Unlike the fixed-price incentive-fee contract, contractor losses are not likely to be incurred. When the allowable costs of a cost-plus-incentive-fee contract are reached, the contractor may stop work but is not required to deliver the final product so long as the contractor has made an honest effort to perform work within allowable costs.

\subsubsection{Allocation of Risk, Teehnological Uncertainty, and Contract Type}

Two important characteristics differentiate contract types: the extent to which incentives for good contract performance are built into the contract and the allocation of risk between contractor and the government [19, pp. 9-12]. Table 2-2 summarizes these characteristics for the contracts described above.

Table 2-2. CHARACTERISTICS OF CONTRACT TYPES ${ }^{a}$

\begin{tabular}{|c|c|c|}
\hline Contract Type & $\begin{array}{l}\text { Incentive for } \\
\text { Cost Performance }\end{array}$ & $\begin{array}{l}\text { Allocations of Risk } \\
\text { of Cost Growth }\end{array}$ \\
\hline Firm Fixed Price & $\begin{array}{l}\text { Large incentives for cost } \\
\text { performance: profits } \\
\text { based on estimated costs }\end{array}$ & Contractor bears all risks \\
\hline $\begin{array}{l}\text { Fixed Price with } \\
\text { Escalation }\end{array}$ & $\begin{array}{l}\text { Large incentives for cost } \\
\text { performance: profits } \\
\text { based on adjusted costs }\end{array}$ & $\begin{array}{l}\text { Contractor bears all risks } \\
\text { except for uncontrollable } \\
\text { changes in input prices }\end{array}$ \\
\hline $\begin{array}{l}\text { Fixed Price with } \\
\text { Redetermination } \\
\text { (Prospective) }\end{array}$ & $\begin{array}{l}\text { Large incentives for cost } \\
\text { performance: profits } \\
\text { based on estimated costs }\end{array}$ & $\begin{array}{l}\text { Contractor bears initial } \\
\text { risks; but renegotiation } \\
\text { reduces future risks }\end{array}$ \\
\hline Fixed-price Incentive & $\begin{array}{l}\text { Incentive for cost per- } \\
\text { formance exists; depends } \\
\text { on formula for distrib- } \\
\text { uting cost savings }\end{array}$ & $\begin{array}{l}\text { Contractor bears risks of } \\
\text { costs above ceiling price; } \\
\text { savings and overruns up to } \\
\text { that point are shared }\end{array}$ \\
\hline Cost Plus Fixed Fee & $\begin{array}{l}\text { Little incentive for } \\
\text { cost consciousness }\end{array}$ & $\begin{array}{l}\text { Government bears all risk of } \\
\text { overruns }\end{array}$ \\
\hline $\begin{array}{l}\text { Cost Plus Incentive } \\
\text { F ee }\end{array}$ & $\begin{array}{l}\text { Incentive for cost } \\
\text { performance exists; } \\
\text { depends on formula for } \\
\text { distributing cost } \\
\text { savings }\end{array}$ & $\begin{array}{l}\text { Government bears all } \\
\text { risks of cost overruns; } \\
\text { benefits of cost under- } \\
\text { runs are shared. }\end{array}$ \\
\hline
\end{tabular}


All of the fixed-price contracts and the cost-plus-incentive-fee contracts provide substantial incentives to the contract performer to keep costs at a minimum; however, the degree of incentive varies. The cost-plus-fixed-fee contract provides less motivation for the contractor to handle costs effectively. Cost overruns are the responsibility of the government, or the contractor may supply less than the originally prom ised product. If a fixed price with retrospective redetermination is used, there would be little incentive to reduce costs, as subsequent renegotiations could raise the contract value to account for cost overruns.

For fixed-price contracts, the contractor bears the risks of losses due to cost overruns and is the recipient of benefits due to cost savings. Escalation and redetermination reduce the risks to the contractor of cost overruns because of unforeseen increases in costs that can validly be accounted for. The incentive fee with ceiling price reduces the contractor risk of overruns up to the ceiling price. The incentive fee, however, also reduces the contractor benefits of cost savings as these savings are shared with the government. At costs above the ceiling cost, the consequences of cost overruns are the exclusive responsibility of the contractor.

The risks of justifiable cost overruns are the responsibility of the government for costplus-fixed-fee and cost-plus-incentive-fee contracts. The benefits of cost savings are shared by the contractor and the government.

Table 2-3. PROCUREMENT OF MAJOR HARDWARE BY TYPE , OF CONTRACT, FISCAL YEAR $1960^{\mathrm{A}}$

(percent)

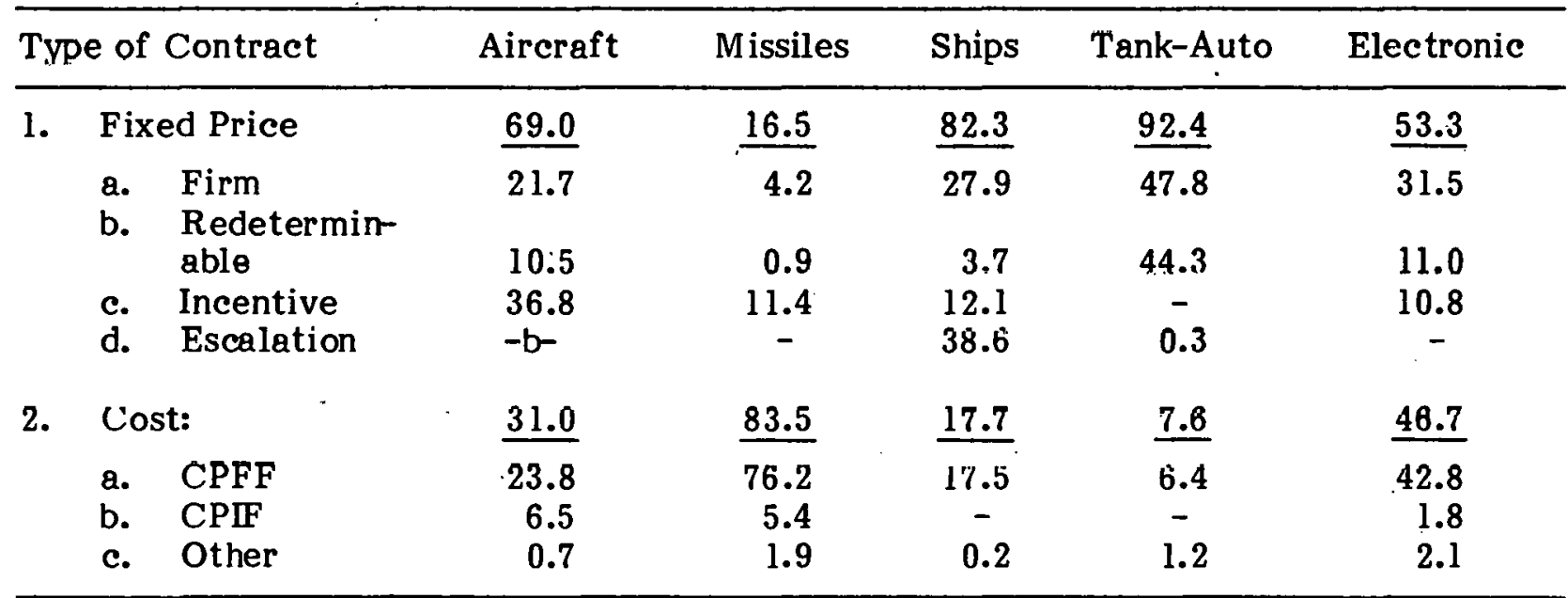

${ }^{a}$ Office of the Secretary of Defense, Military Prime Contract Awards and Subcontract Payments, July-December 1960, Table 18 [19, p. 15].

bIndicates zero.

Table 2-3 shows the types of contracts used by DOD to procure major hardware in 1960 [19, p. 15]. Several observations can be made based on this table. Firm, fixed-price 
contracts have been predominantly used in the acquisition of tanks, automobiles, ships, aircraft, and electronic components. As described by Moore, "The firm fixed price contracts are used in areas where the product can be well defined and where specifications are firm" [19, p. 14]. Other types of fixed-price contracts account for the remaining portions of tank, auto, and ship procurements. A large percentage of aircraft procurements were made with fixed-price incentive contracts. Only missile systems, electronic equipment, and aircraft procurements have relied extensively on cost-plusfixed-fee contracts. Moore explains this application of contract types as follows:

The cost-plus-fixed-fee contract is commonly believed to be the appropriate one when the costs and other circumstances are highly uncertain, and incentive contracts per se are regarded as appropriate when these uncertainties have been reduced. If items can be purchased "off the shelf," the services would presumably use firm fixed-price contracts. Thus, as missile programs begin to firm up, the percentage of CPFF contracts will probably drop, and a larger share will be some kind of incentive contract $[19, p .16]$.

Moore further points out that the average size of firm, fixed-price contracts and fixedprice-with-escalation contracts is relatively small. In 1960, fixed-price contracts averaged $\$ 90,000$, while average sizes of other contracts were 4 to 11 times that of fixed-price contracts. This reinforces the statement that "firm fixed-price contracts are used for small items, semicommercial products" [19, p. 17].

\subsubsection{Contract Performance}

Differences between planned and actual costs of DOD contracts, as well as between planned schedules and system performance and actual results, have been a continual concern of DOD and DOD observers. The increased use of incentive-type contracts in the 1950 s and 1960 s was intended to improve contract performance and reduce cost growth. The outcome of these efforts has not been entirely successful.

The procurement of new weapons systems usually requires advances in the technological state-of-the-art. Accurate estimates of the expected cost of the weapons system, the time of delivery, performance, reliability, and other factors at the time of contract initiation are difficult to make. Historically, contractors as well as government officials have had a tendency to underestimate costs to make a proposed system development eff ort look attractive. Subsequently, contract costs are increased in renegotiations.

Moore points out that the problem of uncertainty and cost growth are not likely to be remedied by use of incentive contracts. He says:

It is fairly common to find that the engineering and technical staff are willing and even eager to accept a tight target or a challenging performance requirement, but the managers in the treasurer's or comptroller's office veto the idea. The latter prefer a safer deal with a smaller profit .. .. if anything, "play it safe" is the "rule" [19, p. 58]. 
The actual results of DOD contract performance were evaluated in a 1972 report by Robert Perry and others [20]. They conclude:

Notwithstanding determined efforts during the 1960 s to improve the outcome of major system acquisition programs by altering contractual approaches and by introducing a variety of management reforms, typical programs continued to exhibit an average cost growth of about 40 percent, a schedule slip of about 15 percent, and final system performance that was likely to deviate by 30 or 40 percent from the original specification [20, p. V.

There are many explanations offered for this disappointing performance. A prominent cause is that contracts have tended to respond to changes in project conditions. Contracts that were intended to offer incentives to keep costs down have been renegotiated when actual costs have exceeded initial costs. It has been shown in one review that the tendency for cost growth increased when the incentive to the contract performer was large, suggesting that the outcome of incentive contracts has been to motivate companies to rewrite contracts to generate new cost savings [21, pp. 153-166].

Perry found a strong correlation between the technological ambitiousness of a program and the resulting cost growth. He suggests that improvements in cost estimation techniques that explicitly account for the technological objectives would be one approach to improve results. He also recommends a more definitive separation between the development phase and the production phase of a system program. The experience of other countries and non-DOD development programs has shown this to be an effective way of dealing with the uncertainties of development programs with little ultimate schedule consequences. The benefits of this approach are "to reduce the incidence of very expensive production line changes that are of ten caused by technical problems dis covered late in the development phase" [20, pp. V-VI].

Perry also suggests that initial development efforts should be funded at a modest level, with emphasis on demonstration of performance. Competitive approaches should be pursued in early stages. Commitments to more-expensive development projects and production of one approach should be made only after technical problems have been resolved. Contracting only for well-defined elements of the new systems development project as opposed to the entire effort, from $R \& D$ to production, would permit greater control of cost and flexibility in development [20, pp. 39-54].

\subsection{DOD/NASA PURCHAȘES AND THEIR INPLUENCES ON THE SEMICONDUCTOR INDUSTRY}

During the past three decades, the federal government has pursued a variety of programs that have supported the development of the semiconductor industry. These programs include funding of research and development, construction of production facilities, as well as purchases of semiconductor components. Determining the influences that these federal activities have had on the semiconductor industry has been the subject of many 
studies. This section reviews these studies to suggest what role federal procurements have played in this industry and how these procurements were structured. The semiconductor industry is of particular interest to photovoltaics procurement strategies because of the close relationship between photovoltaics and semiconductor products. The federal role'in promoting. semiconductor advances has also been singled out as an example for how the photovoltaics program should be pursued. Often, however, important characteristics of the nature of federal semiconductor programs, particularly federal procurements, are misconstrued. This review is intended to highlight these characteristics.

To begin, available data on federal support to the semiconductor industry is presented. Data are presented separately on federal purchases, research, and development. These data provide a general indication of the magnitude of federal programs.: In subsequent sections, the influences and important aspects of these programs are discussed.

\subsubsection{Data on DOD/NASA Purchases}

The U.S. military has become the largest single purchaser of electronics products. Figure 2-1 shows annual sales by the electronics industry for the years 1950, 1960, and 1970. Sales are divided into consumer, industrial, military, and replacement parts markets. In 1950, consumer products were the major market for electronic components, followed by the replacement parts market. Military sales were less than half of consumer sales. By 1960, military sales had grown rapidly. In 1970, defense purchases represented nearly $\$ 10$ billion of industry-wide sales of approximately $\$ 24$ billion. Clearly, the purchasing power of government has become a major influence on the elec tronics industry [22, pp. 9, 10].

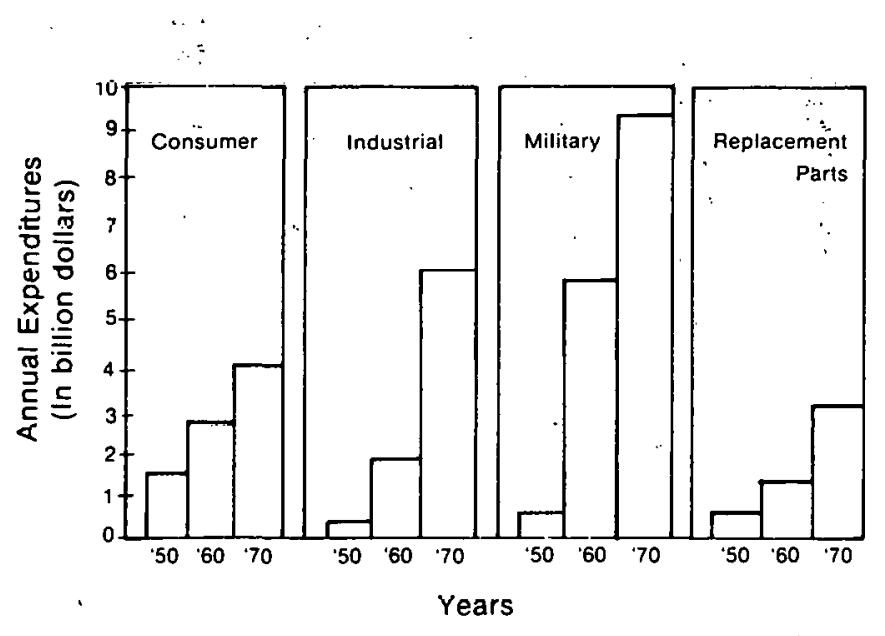

Figure 2-1. ANNUAL SALES IN BASIC ELECTRONICS MARKETS ${ }^{a}$

aurFreund, R. C. "Competition and Innovation in the Transistor Industry." Unpublished Pl.D. dissertution, Duke University, 1971 [22, p. 10]. 
Table 2-4 shows the share of defense purchases in total U.S. semiconductor production. Defense purchases accounted for 36-48\% of semiconductor purchases from 1955-1960, declining to $25 \%$ of industry revenues in the late $1960 \mathrm{~s}$.

It is evident that the U.S. government has dominated the U.S. semiconductor market as well as the U.S. electronics industry as a whole:

Examination of the percentage of U.S. government purchases on a component basis indicates that the government share tends to be greatest when the component is first introduced on the market. Figure 2-2 shows that, as a component matures, the fraction of sales to the government decreases [22, p. 10]. Table 2-5 illustrates this pattern for monolithic intergrated circuits, which were first introduced in the early 1960s. In 1962, defense purchase accounted for all intergrated circuits produced. By 1968, the number of sales made to the U.S. government had declined to $37 \%$. Historically, defense-related purchases have served as an important first market for new semiconductor products. Before examining this market in more detail, the extent of U.S. government-supported R\&D in the semiconductor industry is considered.

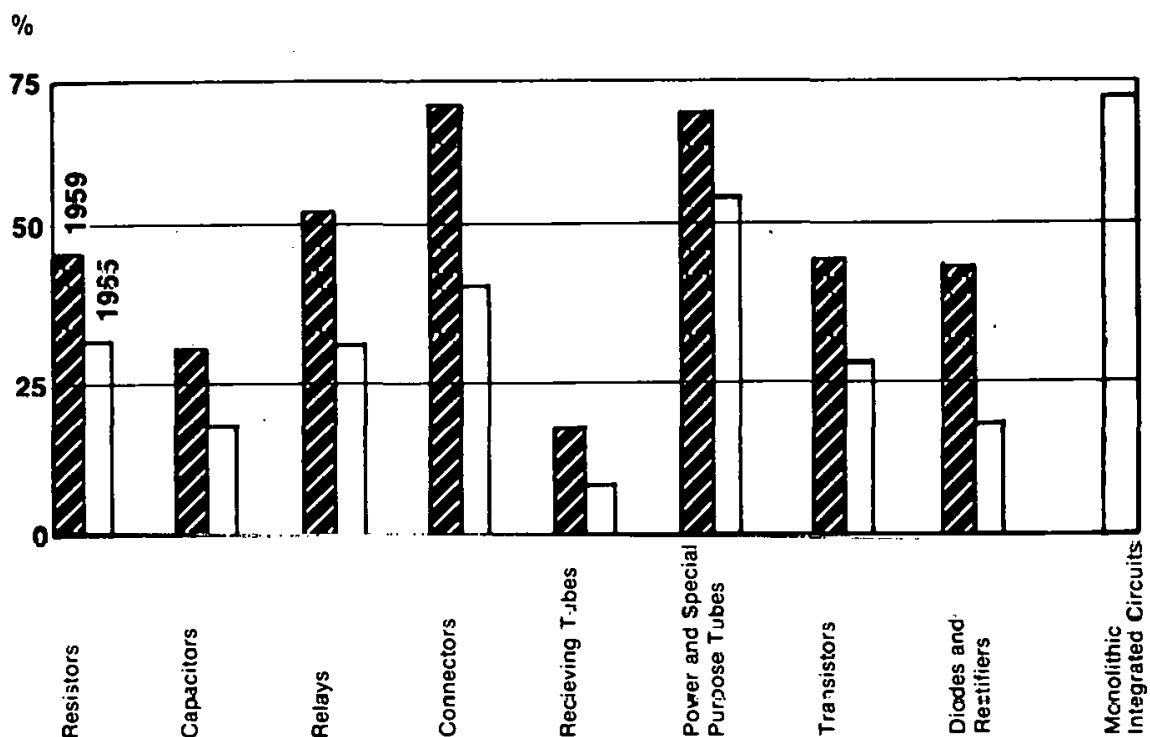

Figure 2-2. UNITED STATES COMPONENTS INDUSTRY Defense Shipments as a Percentagc of Total Shipments, 1959 and $1965^{\mathrm{a}}$

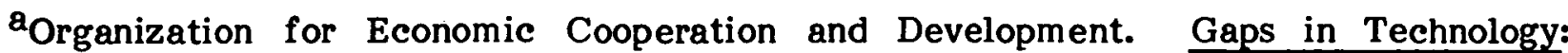
Electronic Components. Paris, France: OECD, 1968, p. 28 [22, p. 11]. 
Table 2-4. U.S. PRODUCTION OF SEMICONDUCTORS FOR DEFENSE REQUIREMENTS, $1955-68^{\mathrm{a}}$

\begin{tabular}{lccc}
\hline Year & $\begin{array}{c}\text { Total Semiconductor } \\
\text { Production } \\
\text { (millions of dollars) }\end{array}$ & $\begin{array}{c}\text { Defense Semiconductor } \\
\text { Production } \\
\text { (millions of dollars) }\end{array}$ & $\begin{array}{c}\text { Defense } \\
\text { as a Percentage } \\
\text { of total }\end{array}$ \\
\hline 1955 & 40 & 15 & 38 \\
1956 & 90 & 32 & 36 \\
1957 & 151 & 54 & 36 \\
1958 & 210 & 81 & 39 \\
1959 & 396 & 180 & 45 \\
1960 & 542 & 258 & 48 \\
1961 & 565 & 222 & 39 \\
1962 & 575 & 223 & 39 \\
1963 & 610 & 211 & 35 \\
1964 & 676 & 192 & 28 \\
1965 & 884 & 247 & 28 \\
1966 & 1,123 & 298 & 27 \\
1967 & 1,107 & 303 & 27 \\
1968 & 1,159 & 294 & 25 \\
\hline
\end{tabular}

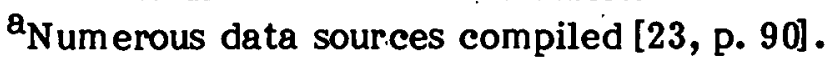

Table 2-5. U.S. INTEGRATED-CIRCUIT PRODUCTION AND PRICES, AND THE IMPORTANCE OF THE DEPENSE MARKET, 1962-68

\begin{tabular}{cccc}
\hline Year & $\begin{array}{c}\text { Total Production } \\
\text { (millions of dollars) }\end{array}$ & $\begin{array}{c}\text { Average Price per Inte- } \\
\text { grated Circuit (dollars) }\end{array}$ & $\begin{array}{c}\text { Defense Production } \\
\text { as a Percentage of } \\
\text { Total Production }\end{array}$ \\
\hline 1962 & 4 & 50.00 & 100 \\
1963 & 16 & 31.60 & 94 \\
1964 & 41 & 18.50 & 85 \\
1965 & 79 & 8.33 & 72 \\
1966 & 148 & 5.05 & 53 \\
1967 & 228 & 3.32 & 43 \\
1968 & 312 & 2.33 & 37 \\
\hline
\end{tabular}

${ }^{a_{V}}$ arious sources compiled [23, p. 91$]$.

\subsubsection{Federal Support for R\&D}

At the same time that the federal government has been a major consumer of electronics products, it has been a significant source of $R \& D$ funds to the electronics industry.

Table 2-6 indicates the amount of funds invested in $R \& D$ for electronics and communication equipment by both the U.S. government and private industry during the period 195768. Government-supported $R \& D$ is consistently estimated to be greater than privately funded $R \& D$. 
Table 2-6. GOVERNMENT AND INDUSTRY R\&D FUNDS FOR -ELECTRONIC COMPONENTS AND COMMUNICATION EQUIPMANT (SIC CODES 366, 367, 481), $1957-68^{\mathrm{Q}}$

(Millions of Dollars)

\begin{tabular}{lccr}
\hline Year & Government & Industry & Total \\
\hline 1957 & 518 & 230 & 748 \\
1958 & 615 & 253 & 868 \\
1959 & 855 & 308 & 1,163 \\
1960 & 944 & 380 & 1,324 \\
1961 & 934 & 470 & 1,404 \\
1962 & 1,074 & 517 & 1,591 \\
1963 & 1,209 & 564 & 1,773 \\
1964 & 1,259 & 613 & 1,872 \\
1965 & 1,292 & 697 & 1,989 \\
1966 & 1,428 & 821 & 2,249 \\
1967 & 1,495 & 930 & 2,425 \\
1968 & 1,538 & 1,000 & 2,538 \\
\hline
\end{tabular}

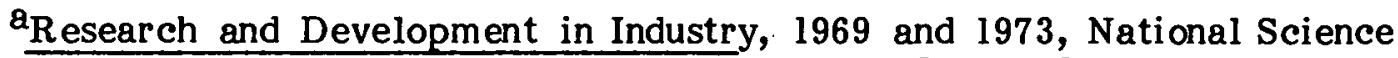
Foundation, NSF 71-18 and 75-315, respectively [24, p. 4]. .

Table 2-7 shows the amount of federal funds spent for direct support of research and development of semiconductors from 1955-1961. R\&D funds were used for general $R \& D$ projects in the semiconductor area. Process refinement funds were used to pay for design and engineering costs associated with the construction of production-plant facilities. Firms receiving process refinement funds (of ten referred to as Industrial Preparedness Studies) were required to assume the capital costs of constructing production plants that met minimum production capabilities specified by the federal government [25, p. 15].

Table 2-7. U.S. GOVERNMENT FUNDS ALLOCATED DIRECTLY TO FIRMS FOR SEMICONDUCTOR RESEARCH AND DEVELOPMENT AND FOR PRODUCTION REFINEMENT PROJECTS, 1955-61

(Millions of Dollars)

\begin{tabular}{|c|c|c|c|c|c|c|c|}
\hline Use of Funds & 1955 & 1956 & 1957 & 1958 & 1959 & 1960 & 1961 \\
\hline Research and Development & 3.2 & 4.1 & 3.8 & 4.0 & 6.3 & 6.8 & 11.0 \\
\hline \multicolumn{8}{|l|}{ Production Refinement } \\
\hline Transistors & 2.7 & 14.0 & 0.0 & 1.9 & 1.0 & 0.0 & 1.7 \\
\hline Diodes and Rectifiers & $\underline{2.2}$ & 0.8 & $\underline{0.5}$ & $\underline{0.2}$ & $\underline{0.0}$ & 1.1 & $\underline{0.8}$ \\
\hline TOTAL & 8.1 & 18.9 & 4.3 & 6.1 & 7.3 & 7.9 & 13.5 \\
\hline
\end{tabular}

a BDSA, Semiconductors: U.S. Production and Trade (196 1), Table 8 [23, p. 93] . 
A DÒD survey conducted in 1960 shows that Pable 2-7 gives only a partial picture of semiconductor $R \& D$. Table 2-8 presents the results of this survey. Government support of $R \& D$ was apparently much greater during 1958-60 than indicated in Table 2-7 (and presumably other years). Table 2-8. includes semiconductor $R \& D$ funds that were embedded in prime weapons projects as well as directly funded R\&D. Estimates of private $R \& D$ expenditures by semiconductor companies are also made in Table 2-8. This table shows that the U.S. government funded approximately $20 \%$ of all semiconductor $R \& D$ between 1958 and 1960. While less prominent than in the electronics and communications industry as a whole, the government has consistently supplied the sēmi conductor industry with substantial $R \& D$ support.

Table 2-8. DIRECT AND INDIRECT GOVERNMENT EXPENDITURES AND PRIVATE R\&D EXPENDITURES IN SEMICONDUCTOR INDUSTRY ${ }^{\natural}$

(Millions of Dollars)

\begin{tabular}{|c|c|c|c|}
\hline & 1958 & 1959 & $\begin{array}{l}\text { January- } \\
\text { April } 1960\end{array}$ \\
\hline Government funds, total $\ldots \ldots \ldots \ldots \ldots$ & $13 . \dot{9}$ & 16.2 & 6.8 \\
\hline Department of Defense ............. & 12.6 & 14.4 & 6.3 \\
\hline 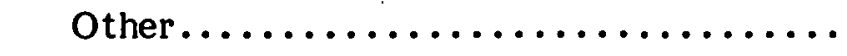 & 1.3 & 1.8 & 0.5 \\
\hline 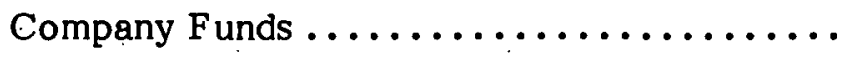 & 41.8 & 54.6 & 25.4 \\
\hline Total Funds & 55.7 & 70.8 & 32.2 \\
\hline
\end{tabular}

\subsubsection{Federal Program Influences}

The federal government has supported the semiconductor industry through direct funding of research and development and purchases of semiconductor products. What have been the influences of these federal programs on the development of semiconductor products and the commercial success of the semiconductor industry? Many studies have attempted to answer this question. Unfortunately, it is impossible to determine definitively the exact effects of specific government activities. To do this, one must know how the semiconductor industry would have progressed without government support-something that can only be speculated. Nevertheless, studies have made consistent interpretations of the relative significance of federal programs. These interpretations are reviewed briefly below. Studies have also suggested which characteristics of previous federal procurement programs were particularly important in enhancing semiconductor industry success. These characteristics are relevant to formulating photovoltaic procurement strategies. 


\subsubsection{Major Semiconductor Innovations and Federal R\&D}

In 1947, Bell Laboratories successfully demonstrated the first point contact transistor. The junction transistor, which had much greater commercial promise than the point contact transistor, was also invented at Bell Labs in 1951. Both of these transistors were made of germanium. In 1954, Texas Instruments produced the first silicon transistors, which could withstand much higher temperatures than germanium and were suited to a wider range of applications. The culmination of all of these inventions was accomplished through private research and development activities. As stated by Braun and MacDonald in their recent history of the semiconductor industry, "In no sense had the invention of the transistor been a military achievement" [26, p. 79].

Similarly, the major developments of the integrated circuit were the result of private R\&D programs. In 1958, Texas Instruments developed the first working integrated circuit. Fairchild Semiconductor Division subsequently developed the planar process in 1961 , which proved to be the key to mass production of integrated circuits.

Although all of the major breakthroughs related to the transistor and integrated circuit were the products of private science, government $R \& D$ funds helped foster the accumur lation of scientific knowledge needed to make these inventions. Braun and MacDonald state:

It is also unrealistic to see the transistor as the product of three men, or of one laboratory, or of physics, or even of the forties. Rather, its invention required the contributions of hundreds of scientists, working in many different places, in many different fields over many years. For example, one could examine the contribution of scores of chemists and metallurgists to an understanding of semiconductors and the development of their abllity to produce them in a form useful to physicists. Without this materials research effort, and particularly the acceleration it received during the war, there could have been no transistor [26, pṕ. 49-50].

Federal R\&D funds also accelerated the development of production capabilities for both the transistor and the integrated circuit. In 1949, Bell Labs received federal development funds for work on the transistor. In 1959, Texas Instruments was funded for development work related to the integrated circuit. Many other companies were supported through $\mathrm{K} \& \mathrm{U}$ contracts for transistor and integrated circuit development. Numerous sources suggest that, while federal $R \& D$ contracts were not directly responsible for major breakthroughs, federal efforts unquestionably advanced the state of the art of both the transistor and integrated circuit and shortened the time needed to develop these devices [21, pp. 24, 34; 24, pp. 4, 57].

The process development efforts for the transistor funded by the Army. Signal Corps illustrate the increase in the pace of development stimulated by the federal government. In $1956, \$ 14$ million was awarded to 12 companies for process development work on 30 different types of transistors. The companies were obligated to develop production facilities capable of producing 3,000 transistors every month. These funds 
forced firms to address the considerable production problems confronting transistors and encouraged several new firms to enter the semiconductor industry [23, p. 92].

The R\&D efforts of the federal government during the late 1950s show how federal programs focused the attention of the semiconductor industry on $R \& D$ to develop miniature circuits. Three different programs were supported by the Army, the Navy, and the Air Force: micromodules; thin films; and molecular electronics. While the integrated circuit was ultimately proven by Texas Instruments to be the most viable concept, government $R \& D$ has been said to have "persuaded industry to allocate its own funds, toward the same goals" $[27$, p. 35$]$.

\subsubsection{The Influence of Federal Procurements}

Federally funded research and development efforts accelerated the development of new semiconductor products. But several sources suggest that federal procurements have had a much larger positive effect on the success of semiconductors. Braun states that one reason that federal purchases of semiconductor hardware are beli eved to have been more significant than federal $R \& D$ is that federal $R \& D$ funds were of ten spent in nonproductive areas. Federal $R \& D$ commitments to molecular electronics as opposed to the integrated circuit and support of larger firms that subsequently were less aggressive in applying new semiconductor technology are two examples of how federal research and development dollars were not effective [26, p. 142]. Tilton, in his study of the semiconductor industry, states:

How important has government $R \& D$ funding been compared with government procurements in stimulating the growth and technological development of the semiconductor industry in the United States? Though evidence is limited, government procurement has probably had a much greater effect. . . The defense market has pumped many more dollars into the industry than the government has in supporting $R \& D$ and production facilities. Moreover, many of the major semiconductor innovations were achieved by firms without any government assistance. Bell Laboratories produced the first transistor with its own funds. And despite the many millions of $R \& D$ dollars the Air Force spent to develop integrated circuits, company-financed $R \& D$ projects produced the major breakthroughs. Only after Texas Instruments achieved a working model of an integrated circuit did it receive an Air Force contract for subsequent development. And Fairchild developed the planar process, which led to the mass production of integrated circuits, without any government support [23, p. 95].

The argument for the constructive role of federal purchases, however, rests on much more than criticisms of the appropriateness of federal R\&D projects or the firms selected to perform those projects. Tilton continues:

The large defense market for semiconductors, which accounts for a significant segment of the overall market, appears to have played a more 
important role in fostering the industry's growth and technological development. It demands the best quality semiconductors. It offers the financial incentives that stimulate the development of better devices for defense equipment, and eventually for commercial products as well; for, in filling military orders, learning economies arise and reduce costs. The defense market is particularly important for new firms hoping to introduce new semiconductor devices and [it] has facilitated their entry [23, p. 97].

It is these characteristics of federal semiconductor procurements that deserve further examination.

\subsubsection{Premium Prices: Emphasis on Reliability and Performance}

One of the most important characteristics of government purchases of semiconductors has been the emphasis on the purchase of devices that met the strict design, performance, and reliability requirements demanded in military and space applications. Kleiman's dissertation on the integrated circuit summarizes this feature:

The various government agencies by their insistent demand for electronic components that were more reliable and smaller continually maintained a pressure on the industry to move toward these goals. The military services and NASA created an atmosphere of urgency which carried a double meaning. For those firms who could develop the desired devices, the government would be a very obvious first customer; for those who did not generate improved components, the government might not be a customer at all $[27$, p. 34].

At the same time that government purchases pressured the semiconductor industry toward technological progress, little or no pressure was placed on industry to reduce costs. As stated by Braun and McDonald:

The military in the early fifties was not primarily concerned with price. Instead, it was more concerned with such matters as availability, whether performance could match military specifications, and whether semiconductor devices would be reliable [26, p. 29].

Utterback and Murray's analysis of the role of the federal government in the electronics industry describes the importance of early military markets as follows: "While the number of prototype and first production units sold for defense demand may have been small, the premium prices paid for new components greatly magnified its importance to the firms involved" [22, p. 13]. Premium prices paid for initial sales allowed companies to realize early profits on successful development efforts. In many cases, the profits made from high-priced government sales allowed companies to further their development efforts. For example, although the invention of the planar process at Fairchild was not supported by federal $R \& D$, government purchases contributed to the success of the company. "Although the breakthrough was made by a company using its own funds, it must be noted that Fairchild earned the money for developing the planar process by 
selling high-priced prototype devices to the government for research purposes" [27, p. 39].

Emphasis on performance and reliability not only pushed the technical capabilities of the semiconductor industry but also prepared the industry for cost reductions needed to service commercial markets. A dissertation on the semiconductor industry by Golding describes the close monitoring of production quality resulting from federal purchases.

Procurement contracts awarded for missile/space programmes since 1958 imposed stringent demands on component reliability. The need to meet tight specifications has, in turn, led to more rigorous production and testing procedures which have had a beneficial effect on commercial devices, again of an intangible kind. The Minuteman Reliability Programmes have influenced both the quality and cost of commercial devices. In general, this transfer has not been direct but operated through the application of knowledge and expertise gained from involvement. in high reliability exercises to commercial products. ... The emphasis on reli ability isolates troublesome processes on which $R \& D$ resources can be brought to bear. Enhanced understanding of the faulty process often results in higher yield and reduced cost $[25$, p. $61-62]$.

The rapid declines in the price of semiconductor devices which followed the initial sales to military markets permitted sales in industrial and consumer markets. Reductions in price were the results of improvements in production techniques both from process innovation and production experience as well as intense industry competition. The government market set the pace for semiconductor technology development. As new devices were introduced into the government market at high price, companies were well positioned to address the problem of how to make the device cheaper.

\subsubsection{Support for New Firms}

New companies entering the electronics industry with new semiconductor devices played an important role in the development of the industry. The differences in support offered to these new firms through government $R \& D$ funds and government procurement illustrates an important function of federal purchases. Braun summarizes the situation:

By 1959, Western Electric and the eight valve firms were still receiving 78 percent of government $R \& D$ funds though they held only 37 percent of the total market. New firms, with only 22 percent of the government $R \& D$ funds, had, by then, captured 63 percent of the semiconductor market. At this time the older companies were themselves providing about two-thirds of their R\&Dexpenditures and new firms about 90 percent. The semiconductor industry as a whole benefited, from government funds, but the older firms benefited very much more than the newer $[26$, p. 81$]$.

Concentration of federal $R \& D$ funds in established firms is. consistent with the performance of these companies in developing semiconductor products. Bell Labs and receiving 
tube companies were responsible for the majority of semiconductor patents in the 1950 s [23, p. 52]. But newer companies were much more aggressive in applying new technology.

Federal procurements recognized the role of new firms. Tilton explains:

The defense market has been particularly important for new firms.... These firms often have started by introducing new products and concentrating in new semiconductor fields where the military has usually provided the major or only market. Fortunately for them, the armed forces have not hesitated to buy from new and untried firms. In early 1953, for example, before Transitron had made any significant sales, the military authorized the use of its gold-bonded diode. This approval has been called the real turning point for the new firm. During 1959, new firms accounted for 63 percent of all semiconductor sales and 69 percent of military sales. Military demand has therefore stimulated the formation of new companies and encouraged then to. develop new semicondueturs by promising the suc cessful ones a large market at high prices and good profits [23, pp. 91-92].

This support of new companies by federal purchases induced industry competition and accelerated the application of new semiconductor devices.

\subsubsection{Demonstration Effects of Federal Purchases}

The discussion above has focused on the importance of federal procurements to the development of semiconductor industry supply capabilities. However, the positive influence of federal purchases on the nongovernment demand for semiconductor products cannot be ignored. Federal purchases and application of semiconductor devices convinced both other potential government buyers and prospective private purchasers of the ability of semiconductors to satisfy user needs. Golding describes the demonstration effects of these procurements.

Quite apart from cost considerations, equipment designers hesitated to make use of an unproven component in any quantity. In retrospect, it appears that two decisions during 1062 wcre rcsponsiblc for the requidito breakthrough leading to the large-scale acceptance of the IC [integrated circult]. NASA arriounced an intention to utilizing ICs for its prototype Apollo space craft guidance computer. Then, at the end of 1962, the Air Force publicly stated that an improved version of the Minuteman I, ICBM would make maximum practical usage of ICs in its guidance mechanism [25, p. 55].

\subsubsection{Procurement as an Inducement for Private R\&D}

Numerous sources have mentioned that profits from federal procurements help reduce further expenditures on research and development. The importance of federal 
procurements for funding $R \& D$ in new firms was mentioned above. Ninety percent of the $R \& D$ performed by new semiconductor companies in 1959 was funded by internal funds generated through sales, the majority of which were to the federal government [23, p. 81, 82]. Activities at Fairchild and Transitron are good examples of development work that was made possible by federal procurements. Computer sales to the federal government have been shown to permit companies participating in federal procurements to maintain higher levels of $R \& D[28, p .10]$. Given that the majority of innovations in the semiconductor industry were supported by private funds rather than direct $R \& D$, the R\&D activity funded through federal procurements is especially significant.

\subsubsection{Nature of Procurement Contracts}

In the studies of semiconductor procurements reviewed, little discussion is devoted to the exact nature of semiconductor procurement contracts. Golding, however, discusses the importance of concentrating semiconductor purchases in a few firms.

One significant feature is that purchases have usually been deliberately concentrated in only a few firms. A small number of large orders allows dynamic economies of scale to operate with maximum effect. Dispersion among several firms would undoubtably dissipate the impact [25, p. 60] .

Golding goes on to discuss the significance of long-term contracts.

But the essential value of the long-term contract lies in its ability to insulate the recipient firm from the vicissitudes of the market. . . . Longterm contracts confer stability on the vendor..... The stability of the long-term procurement contract accordingly provides an environment highly conducive to yield improvement and it is this which of ten lies at the root of precipitate reduction in unit cost $[25$, p. 61$]$.

These two features of semiconductor procurement were intended to provide individual firms with sufficient guaranteed volume and future demand to implement cost reducing production techniques.

\subsection{CONCLUSIONS OF REVIEW RELEVANT TO PHOTOVOLTAIC PROCUREMENTS}

This review has shown that a well-established tradition of federal procurement exists. Procurements have historically been an effective means of stimulating technological inuovation, partlcularly when these innovations can be used by the federal government itself. The role played by federal procurements in the development of the semiconductor industry is a dramatic example of the positive influence that procurements can have on technological innovation.

Recently, the federal government has become more concerned with using federal procurements to advance selected civilian technologies. Photovoltaic procurements illustrate this interest. Promoting technologies for use primarily in the private sector is 
a divergence from previous procurement programs. This is not to say that past innovations with great commercial significance have not been fostered by federal procurements. Semiconductor devices show that procurements of new products initially for use by the federal government of ten have widespread applications in other markets. However, the dynamics of federal procurements, primarily intended to encourage the development and use of new products for private markets, are somewhat different than those intended solely to satisfy federal needs. Yet, past experiences with federal procurements and established procurement policies offer some guidance for designing an effective procurement program for photovoltaics, as well as other technologies that could be socially beneficial to nongovernment users. The implications of past federal procurement policies and programs as they relate to photovoltaic procurements are summarized here. Issues relevant to currently propased procurement strategies, such as a large fixed-price procurement that attempts to stimulate cost reductions by concentrating purchases in a small number of companies, are given special attention.

\subsubsection{Fixed-Price Contraets Are Typically Used for Well-Defined Products and} Production Processes Which Have Long Histories of Commercial Production

The basic element of a fixed-price contract is that all risks of cost overruns are borne by the contract performer. Companies are usually reluctant to carry all the risks of a contract when they are uncertain of the actual costs of meeting contract terms. For new products or products with uncertain future production costs, production techniques, or systems designs, the federal government has historically used other contracting mechanisms which either share risks with industry (i.e., incentive contracts) or carry risks entirely (i.e., cost-plus-fixed-fee contracts). The question relevant to photovoltaic procurements is, will industry bear the risks of large fixed-price contracts that call for progressively lower module prices in future years? The answer to this question rests on the confidence that photovoltaic suppliers have in future costs of production. If a fixedprice procurement of complete photovoltaic systems were pursued, then system suppliers would need to be certain of the designs and costs of the systems being purchased.

\subsubsection{Early DOD Purchases of Semiconductor Products Emphasized Performance, Reliability, and Design Requirements; Innovative Products Were Purchased at Premium Prices}

Perhaps the major benefit of government procurements was that companies with a new semiconductor device were almost guaranteed an initial market in which they could make a stable profit. The government market acted as a reward for successful technological developments. Profits from early sales to the government made the semiconductor industry an attractive business opportunity. In many cases, these profits were applied to additional development activities that resulted in new devices and new production approaches that were lower in cost. It is difficult to estimate the effects of procurements that pressure the photovoltaic industry to lower prices. Excessive pressure on prices may reduce the positive influence that federal purchases could have on technological innovation. Federal markets could even become more price competitive than private markets. Procurements that are based solely on prices are likely to favor 
currently understood production techniques because these techniques currently have the lowest costs. Little incentive would exist to explore more innovative production techniques that ultimately may promise lower costs. A company would have to supply an innovative product at prices below cost to be competitive in federal procurements. Companies would have difficulty financing these losses, even if expected future gains are significant. In addition, there would be very little revenues available to pay for $R \& D$ needed to bring an innovative technology to production. New companies, in particular, have problems attracting capital for products they will be forced to sell at losses in early years.

\subsubsection{Early DOD Semiconductor Purchases Stimulated Industry Competition; Yet Photovoltaic Purchases Will Need to Be Concentrated in a Few Firms to Encourage Investments in New Production Techniques}

Another positive aspect of DOD semiconductor purchases was the willingness of the federal government to buy from numerous firms, both large and small. It has been shown that government purchases encouraged several new companies to enter the semiconductor business with new products. A fixed-price photovoltaics procurement program with the objective of cost reduction would need to provide companies with large contracts that significantly expand their planned production capabilities. Federal budget limitations would require, therefore, that contracts be awarded to a few companies. In DOD semiconductor purchases, this conflict may have been less troublesome because many series of procurements were made with individual contracts of substantial size. Concentration of federal photovoltaic purchases undoubtedly would reduce the number of companies with an active interest in photovoltaics. Disbursement of purchases to numerous firms means that federal procurements may do little to change the production techniques and costs of any single firm. Yet, support of many firms may stimulate more private sector activity in photovoltaics and encourage investigation of a diverse set of technological and business approaches to photovoltaic industry development.

\subsubsection{Successful Commercial Produets Have Resulted from Programs Which Have Made Convineing Demonstrations of the Usefulness of the Product}

Federal procurements accelerated the diffusion of new semiconductor devices by demonstrating their performance and reliability. The use of integrated circuits in the Minuteman II and Apollo programs encouraged other government military and space programs to considel using integrated circults in thelr own systems. Industrial consumers were also relieved of any doubts regarding the capabilities of the integrated circuit. A critical element of any federal photovoltaics procurement program, regardless of contracting mechanism, is to use purchased hardware in applications that provide essential information on how photovoltaic systems work. These application projects can inform potential purchasers about photovoltaic system characteristics at the same time that they educate producing companies about user requirements. 


\subsubsection{Little Precedent Exists for Federal Purchases in Excess of Needs}

Procedures for federal procurements have been developed to economically and efficiently satisfy the needs of the federal government. For advancing technologies that have been determined to be socially beneficial, definition of federal needs has of ten been broadened to include the construction of experimental and demonstration facilities to gather technical and market information. In most cases, the magnitude of federal purchases needed to accomplish these assistance objectives is small. Federal procurements of photovoltaics in quantities in excess of those needed to obtain information and service federal facilities represent an approach to procurement with little precedent. The justifications for aggressive procurements of this nature, such as lower photovoltaic system costs or acceleration of industry development, need to be carefully examined. It is likely that if the objective of a federally supported photovoltaic purchase program was to encourage private sector applications, this program would be called an assistance program. Assistance programs are typically carried out through cooperative agreements and require substantial private sector cost sharing. 


\section{SECTION 3.0}

\section{METHODOLOGY FOR ASSESSMENT OF INDUSTRY RESPONSES TO ALTERNATTVE PROCUREMENT STRATEGIES}

The review of federal procurement policies and programs raised several issues worth exploring with the photovoltaics industry. Several outstanding issues concerning future DOE photovoltaic procurement programs, particularly the proposal for a large fixedprice photovoltaic procurement at sequentially lower prices, needed to be considered. To address these issues, a series of interviews was conducted with selected photovoltaic manufacturers and performers of research and development. This section describes the methodology used in these interviews and identifies the companies and individuals visited.

\subsection{PROCUREMENT STRATEGIES FOR DISCUSSION AND INTERVIEW METHOD- OLOGY}

To focus the interviews, five sample federal photovoltaic procurement programs were outlined. These "strawmen" strategies were intended to bracket the range of possible approaches to federal photovoltaic procurements and to raise issues of particular interest.

Each interview was begun by presenting the five strategies, explaining them, and answering any basic questions about them that the interviewees had. Then, a general discussion was held comparing the strategies, describing their strengths and weaknesses, and speculating on what each strategy would mean for the activities of the individual company and the photovoltaic industry as a whole. Companies were informed that none of the strategies represented official DOE policies. It was stressed that the actual approach to procurements that will be followed by DOE could be a combination of the strategies presented or possibly another approach. Companies were told to assume that the DOE photovoltaic technology development and advanced research and development programs continue as currently planned. To ensure open discussion, it was promised that responses would not be attributed to specific companies or individuals.

Table 3-1 presents the first strategy. This strategy approximates the existing systems test and applications program planned by DOE. Expenditures for the Federal Photovoltaic Utilization Program (FPUP) have been added to the systems test and applications program budgets in FY80-FY83. As no spending rate for FPUP has been determined, an estimate of annual FPUP rexpenditures was made to arrive at the budget in Table 3-1. It was assumed that the systems test and application program and FPUP would be pursued jointly. The type of contract used under Strategy 1 would be similar to the contracts used in the present photovoltaic systems test and applications program; i.e., Program Research and Development. Announcements (PRDA). These are cost-plusfixed-fee contracts for the entire photovoltaic system and are often not with a module 
manufacturer but with a system or research company that has assembled the PRDA team. The duration of the contract in which hardware is actually procurred and installed is short (one year or less), although provisions for system design and monitoring may extend over one or two years. PRDA proposals are typically evaluated based on a number of criteria including the application proposed, the system design, and cost. The actual prices of the systems constructed are primarily determined by the competitive prices bid in PRDA proposals. This program results in numerous project awards.

Projects will vary greatly in size depending on the applications selected. The dollar value of contracts to successful companies also depends on the size and number of systerns selected.

Table 3-1. STRATEGY 1: NO FIXED-PRICE, MODERATE BUDGET

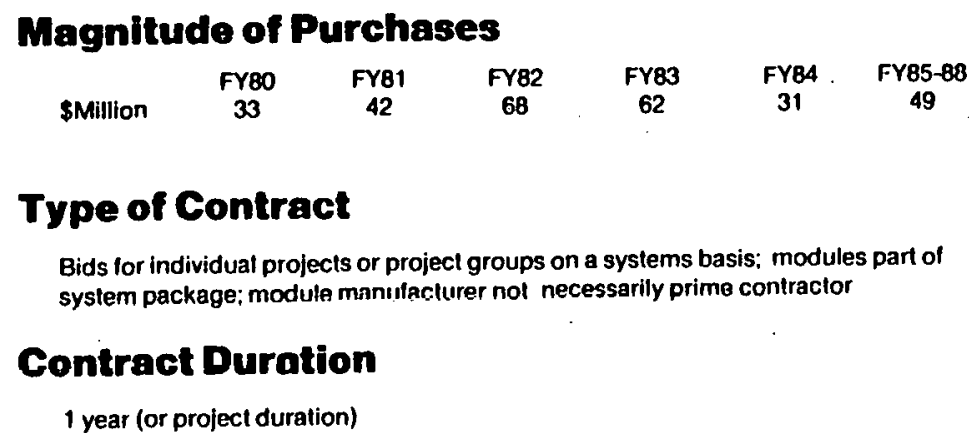

\section{Contract Requirements}

Compelitive bid dotermined prices

\section{Number of Contracts}

Numerous; project sizes range from $1-800 \mathrm{kWp}$

\section{Estimated Contract Value to Successful Company}

Highly varlable; depends on number and size of successlul project bid

The second strategy has the same overall budget as Strategy 1 (see Table 3-2). In FY80 and FY84-88, the program proneeds using thc PRDA ariaigement and contracts are awarded for complete systems. In FY81-83, a different approach is taken. Large centralized procurements are made for photovoltaic modules. Three-year contracts are awarded to four companies under this program. Bidding companies would be required to deliver modules to the federal government in each year at the prices indicated under contract requirements. Thus, a successful company would deliver almost $1 \mathrm{MW}_{\mathrm{p}}$ in FY81 at $\$ 5 / \mathrm{W}_{\mathrm{p}}$ and nearly $2.5 \mathrm{MW}_{\mathrm{p}}$ in FY83 at $\$ 2.50 / \mathrm{W}_{\mathrm{p}}$. The total value of the contract to a successful company would be approximately $\$ 17.6$ million. A separate set of systems contracts would be awarded to construct complete photovoltaic systems with $\gamma^{\text {the }}$ 
modules procurred under this program.* This strategy also was discussed as a fixed-price purchase of systems rather than just modules.

Table 3-2́. STRATEGY 2: FIXED-PRICE, MODERATE BUDGET

\begin{tabular}{|c|c|c|c|c|c|}
\hline \multirow{2}{*}{$\begin{array}{l}\text { SMillion } \\
\text { MWP }\end{array}$} & $\begin{array}{c}\text { FY80 } \\
33\end{array}$ & $\begin{array}{cc}\text { FYB1 } & \text { FY82 } \\
17.5 & 25.5 \\
3.5 & 8.5\end{array}$ & $\begin{array}{l}\text { FY83 } \\
27.5 \\
11\end{array}$ & $\begin{array}{l}\text { FY84 } \\
30\end{array}$ & $\begin{array}{l}\text { FY85-88 } \\
\text { 50 }\end{array}$ \\
\hline & $\begin{array}{c}\text { No Fixed } \\
\text { Price: System } \\
\text { Purchases }\end{array}$ & \multicolumn{2}{|c|}{$\begin{array}{l}\text { Fixed Price Procurement: } \\
\text { Modules }\end{array}$} & \multirow{2}{*}{\multicolumn{2}{|c|}{$\begin{array}{l}\text { No Fixed Price: } \\
\text { System Purchases }\end{array}$}} \\
\hline \multicolumn{4}{|c|}{ Type of Contract } & & \\
\hline
\end{tabular}

\section{Contract Duration}

3 years

\section{Contract Requirements}

Module prices not to exceed the following (in 1980 dollars):

$\begin{array}{llc}\text { FYB1 } & \text { FYO2 } & \text { FYB3 } \\ \$ 5 / W p & \$ 3 / W p & \$ 2.50 / W p\end{array}$

\section{Number of Contracts}

\section{4}

\section{Estimated Contract Value to Successful Company}

$\$ 17.6$ million

Strategy 3 follows an approach similar to the Fixed-Price, Moderate Budget Strategy, except it is more aggressive in a number of dimensions (see Table 3-3). The program begins in FY80 and lasts for five years. The hudget is more than double the budget of Strategy 2 and represents a much greater allocation of funds to photovoltaic procurements than presently planned. The maximum price schedule required from contractors bidding this program declines more rapidly and ends at a lower final price in $1984, \$ 1.50 / \mathrm{W}_{\mathrm{p}}$. Finally, the total value of the contract to a successful company over the five-year period, assuming it supplies one-fourth of the purchases, is in excess of $\$ 40$ million. This program represents a very aggressive attempt on the part of the federal government to stimulate photovoltaic production capacity expansion and system cost reductions through federal procurements. An aggressive procurement of systems rather than modules was discussed again as an alternative.

*The program budget shown in Table 3-2 for FY81-83 is lower than the Strategy 1 budget in those yeurs to account for balance of system costs that would be incurred. in constructing systems. 
Table 3-3. STRATEGY 3: FIXED PRICE, AGGRESSIVE BUDGET

Magnitude of Purchases

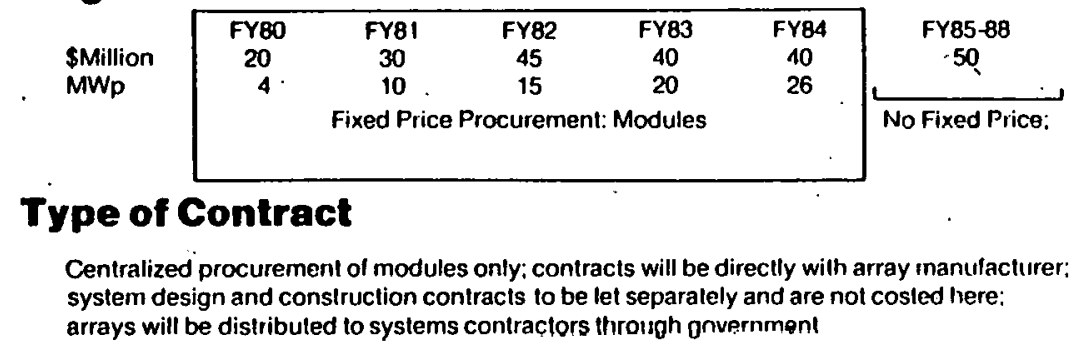

\section{Contract Duration}

5 years

\section{Contract Requirements}

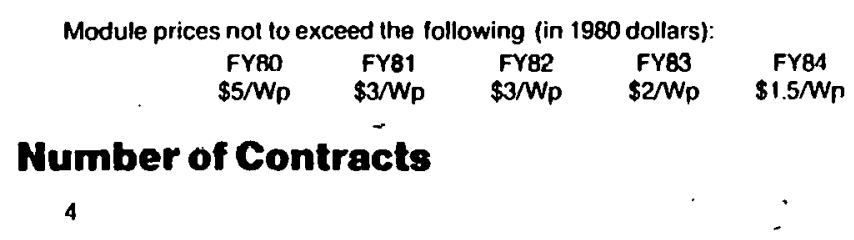

\section{Estimated Contract Vaiue to Successful Company}

$\$ 43.7$ million

Strategy 4 represents the concept of supplying "up front" subsidies for pilot production facilities and subsequently purchasing a small portion of the output of the facilities at a fixed price, indicated in Table 3-4 to be $\$ 2.50 / \mathrm{W}_{\mathrm{p}^{*}}$. This approach is in some respects similar to the pilot facilities support supplied by the federal government to companies for manufacturing transistors during the 1950s. The total budget for this program is approximately equal to the Fixed Price, Moderate Budget Strategy (Strategy 1), with the addition of $\$ 20$ million in FY81 to cover the pilot facility subsidies. Companies would be expected to share the pilot facility capital cost with the government. Four-year contracts would be issued and reguire that the compnny supply thuguvcrnment with all cost and technical information on the operation of the plant. Contracts would be awarded for both the plant construction and $1 \mathrm{MW}$ of production output in FY83 and FY84. If four contracts were awarded, the total value of a contract to a successful company would be approximately $\$ 10$ million.

Strategy 5, Innovative. Product Procurement, follows the approach used in the semiconductor industry to purchase innovative semiconductor devices (see Table 3-5). Three-year contracts would be awarded to manufacturers to produce a small quantity of modules. The thrust of this program would be to provide early production experience for innovative modules with cost reduction potential that would not be able to compete in a procurement in which lowest initial cost is the major evaluation criterion. Proposals would be evaluated according to the technical merits and status of the technology proposed. If five contracts were awarded, each contract would be approximately $\$ 6$ million. In this strategy, it was assumed that the system purchases for test and applications projects outlined in Strategy 1 would be pursued simultaneously. 
Table 3-4. STRATRGY 4: EXPERIMENTAI, PRODUCTION FACHLTIES AND FIXEDPRICE BUYS

Magnitude of Purchases

\begin{tabular}{|c|c|c|c|c|c|c|}
\hline \$Million & FYBO & $\begin{array}{c}\text { FY81 } \\
20\end{array}$ & FY82 & $\begin{array}{c}\text { FYB3 } \\
10\end{array}$ & $\begin{array}{l}\text { FYBA } \\
10\end{array}$ & FY85-88 \\
\hline . & & $\begin{array}{l}\text { Pilot } \\
\text { Facilities } \\
\text { Subsidy }\end{array}$ & & $\begin{array}{l}\text { Fixed-Pri } \\
\text { Modul } \\
12 \\
\text { BOS } \overline{C o}\end{array}$ & $\begin{array}{l}\text { curements: } \\
2.50 / W_{p} \\
12 \\
\$ 3.00 / W_{p}\end{array}$ & . \\
\hline & $2 B$ & 47 & 68 & 40 & $\mathbf{y}$ & 49 \\
\hline
\end{tabular}

\section{Type of Contract}

Each contract is for pilot facility capital cost (cost-slıared) and for modules; syslems contracts handled separately

\section{Contract Duration}

4 years; each company must operate plant through 1984: must supply government with all cost and technical information

\section{Contract Requirements}

Modules prices cannol exceed $\$ 2.50 / W p$ in FY83 and FY84; production plant cost sharing required: awards based on expected costs of output and supporting documentation

\section{Number of Contracts}

4

\section{Estimated Contract Value to Successful Company}

$\$ 10$ million

Table 3-5. STRATEGY 5: INNOVATIVE PRODUCT PROCUREMENT

\section{Magnitude of Purchases}

\begin{tabular}{|c|c|c|c|c|c|}
\hline \$Million & FYBO & FYB1 & $\begin{array}{c}\text { FY82 } \\
10 \\
\text { Innovative }\end{array}$ & $\begin{array}{cc}\text { FY83 } & \text { FY84 } \\
10 & 10 \\
\text { roduct Procurement: } \\
\text { Módules }\end{array}$ & FY85-88 \\
\hline & 28 & 47 & 68 & $\begin{array}{ll}62 & 31 \\
\end{array}$ & 49 \\
\hline
\end{tabular}

\section{Type of Contract}

Modules only: modules could be used in systems lests depending on performance and reliability

\section{Contract Duration}

3 years

\section{Contract Requirements}

None; evaluation criterion is potentlal for cost reduction; procurement will provide Initial production experience for new production techniques

\section{Number of Contracts}

5

\section{Estimated Contract Value to Successful Company}


After the strategies were reviewed with the interviewees, a series of informal questions were asked. The interviews, which were conducted by the authors of this report, emphasized different strategies and issues depending on the interests of the company. In many respects, each interview was unique. However, two groups of companies consistently focused on different strategies and issues. These two groups are companies currently producing photovoltaic modules and companies that are potential producers but currently limit their photovoltaic activities to research and development. The companies in these two groups and the individuals interviewed are identified below.

Even though the discussed topics varied according to the interests of the companies, an effort was made to discuss several issues with all companies. Companies were asked to give their general reuctions to the strategies from their own perspectives, describe the strengths and weaknesses of the strategies, and indicate which programs they preferred and which ones they would participate in. Companies were also asked to consider the strategies from an industry perspective. Of particular interest were the impacts of the strategies on the number of companies likely to be active in the photovoltaics industry in the future; the diversity of technologies being pursued and the level of private $R \& D$; private market sales of photovoltaic systems; and future photovoltaic system and module prices. For the strategy most interesting to each company, companies were asked to describe how their $R \& D$ plans and production plans would be changed if they were awarded a contract under this strategy. Changes in company plans if not awarded a contract were probed. A number of special issues were explored also. These included the reasonableness of the strategy schedules; any problems in material or production equipment availability; the types of systems that should be constructed with the hardware purchased under any of the strategies; and perceptions of future photovoltaic sales rates and the portion of sales accounted for by federal procurements. Companies also were asked to suggest any modifications in slrategies that would make them more attractive. A few modifications in some instances were proposed by the interviewers to solicit company reactions. These included modifying Stratcgy 2 to be a fixed-price procurement of complete photovoltaic systems and increasing the number of contracts awarded under each of the strategies. Alternative mechanisms for negotiating module prices in Strategy 2 were explored, such as allowing companies to bid thelr own price schedules for the years FY81-83. The implications of delaying the start of Strategy 2 until FY83 were discussed also.

\subsection{COMPANIES PARTICIPATING IN I'HE STUDY}

Table 3-6 lists the 13 companies visited and the individuals interviewed at each company. Seven of the interviewed companies currently are producing photovoltaic modules while six are potential producers. In some cases, only one person participated in the interview, although in others there were several. Companies were asked to have their technical and marketing expertise as well as management perspective represented. The number of individuals with this knowledge varied from company to company. 
Table 3-6. COMPANIES AND INDIVIDUALS PARTICIPATING IN STUDY

\section{CURRENT PRODUCERS}

Company

Solarex Corporation

Solenergy Corporation

Sensor Technology, Inc.

Optical Costing Laboratory, Inc.

Motorola Semiconduc tor Products, Inc.

ARCO SOLAR, Inc.

Solar Power Corporation
Individuals Interviewed

Joseph Lindm ayer, President John Goldsmith, Vice President

Robert Willis, President

Irwin Rubin, President Sanjeev Chitre, Director, Solar Operation

Douglas O'Connor, President, Photoelectronics Division

Raymond Mattison, Manager, Corpora te Market Developm ent

Robert Brown, Manager, Terrestrial Solar Power Programs

Bill O'Connor, Director, Solar Energy

Robert McGinnis, Manager, Solar Ope rations

Thomas McLaughlin, Vice President and General Manager

J. W. Yerkes, Vice President, Engineering and Research

Kenneth Ude, Coordinator, Market Research

W. W. Hawley, Manager of Programs

John Wurmcer, President

Paul Caruso, Vice President

William Brusseau, Marketing Manager

POTENTIAL PRODUCERS

\section{Sun Trac Corporation}

RCA
Douglas Moeller, President

James Frommeyer, Consul tant

Howard Rosenthal, Staff Vice President of Engineering, David Sarnoff Research Center

Brown Williams, Director of Photovol taic Research Arthur Firester, Head, Process and Applications Research David Carlson, Group Head, Photovol taic Devices 
Table 3-6. COMPANIES AND INDIVIDUALS PARTICIPATING IN STUDY (concluded)

POTENTIAL PRODUCERS (concluded)

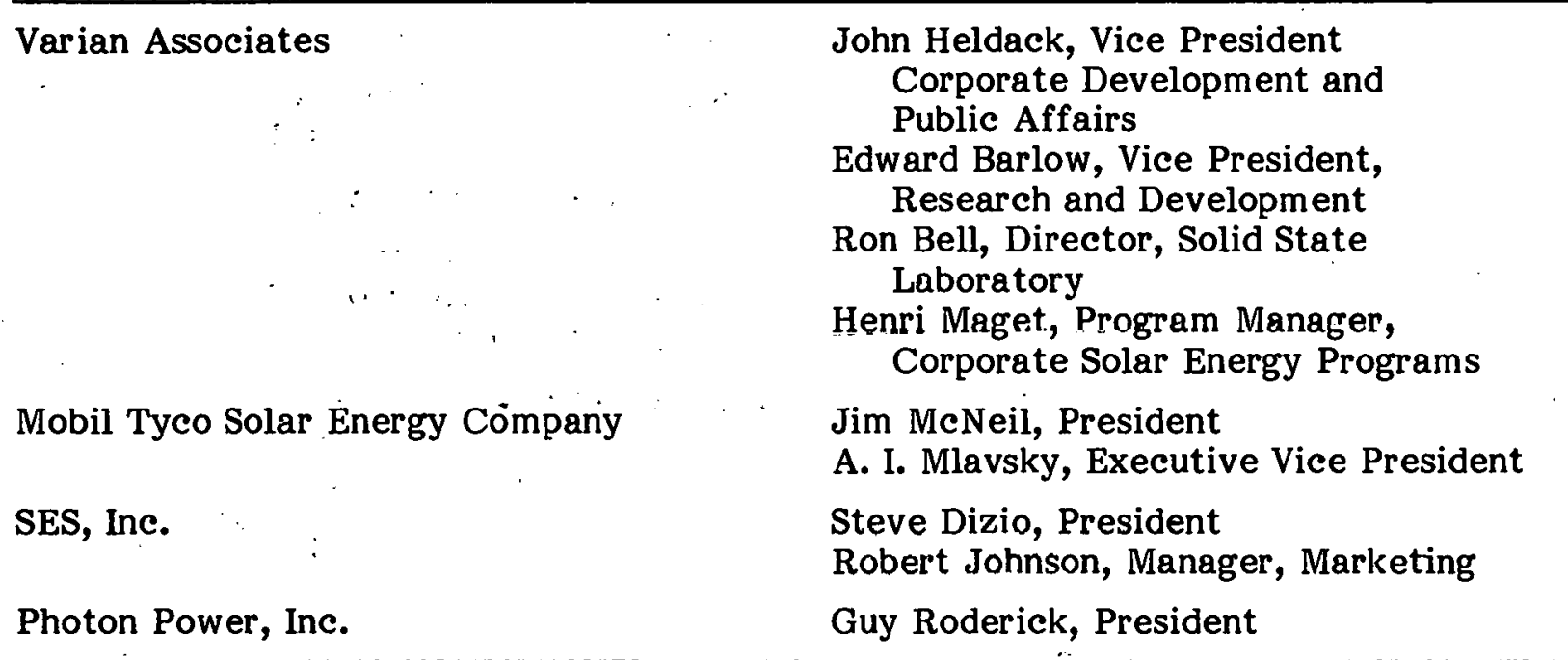

The companies participating in this study do not include all companies active in photovoltaic $R \& D$ and production today. However, they do represent the majority of current production, the diverse technological approaches under investigation, and the various types of companies with photovoltaic programs.*

The producing companies participating in the study essentially comprise all of the current production and sales of the photovoltaic industry. All of these companics are manufacturing single crystal silicon modules, although several are involved in $\Omega \& D$ on other approaches, such às semicrystalline silicon.

Two of the potential producers, Photon Power and SES, are working on pilot scale production of cadmium sulfide modules. Mobil Tyco is conducting $R \& D$ and constructing a pilot production" plant for Edge-defined, Film-fed Growth (EFG) ribbon silicon cells. RCA.is working with amorphous thin-film cells and polycrystalline thin film cells. Variun is conducting $R \& D$ related to single-crystal gallium arsenide cells for use in concentrating modules. Sun Trac is developing concentrating modules that use silicon cells.

Solarex,** Solenergy, and Sun Trac are independent small companies. OCLI and Sensor Technology are moderate-sized electronics companies that produce many other products in addition to photovoltaics. Motorola, RCA, and Varian are large electronics companies with diverse products lines. ARCO Solar, Solar Power (Exxon), Mobil-Tyco, SES (Shell), and Photon Power (CFP) are majority owned by energy companies.

*See Appendix A for a profile of the photovoltaic industry. This appendix traces historical sales and price trends, and identifies the activities of companies with photovoltaic programs.

**Since this study was conducted, Standard Oil (Indiana) has purchased a minority interest in Solarex Corporation. 


\section{SECTION 4.0}

\section{COMPANY RESPONSES TO ALTERNATIVE PROCUREMENT STRATEGIES}

This section summarizes the responses to the five procurement strategies presented. Responses to each strategy are summarized individually in order to construct scenarios of likely events under each program. The summaries presented here focus on the strengths and weaknesses of the strategies and indicate modifications that were suggested.

In analyzing the results of the interviews, the responses of different types of companies were examined. Figure 4-1 shows company groupings relevant to the discussion of photovoltaic procurement strategies. Two considerations are used to group companies. The first is the business status of the company. The important distinction is that some companies are currently producing and marketing. photovoltaic systems, whereas others are confined to research and development and are not yet active suppliers of commercial products. The second consideration that distinguishes companies is their financial backing and primary business activity. For example, some companies are subsidiaries of major energy companies, whereas others are small divisions in large- and moderate-sized electronics companies. The final group is of those exclusively involved in photovoltaics and independently financed. These two dimensions tend to separate company opinions. In some cases, emphasis on production or $R \& D$ is the most important factor. In others, it is financial backing and primary business activities. Sometimes, the specific technological approach of the company (i.e., flat-plate or concentrator, silicon or cadmium sulfide) also shapes a company's point of view. Throughout the summaries that follow, the opinions of particular groups, when significant, are reported. As stated earlier, the opinions of specific companies or individuals are not identified.

\subsection{INDUSTRY RESPONSES TO STRATEGY 1: NO FIXED-PRICE, MODERATE BUDGET}

Table 4-1 presents positive features and problems of the no fixed-price, moderate budget strategy that were identified by different company groups. "All groups" in Table 4-1 indicates that the corresponding point was expressed by companies representing all company groups, although not .every company interviewed may have made the point.* The number in parentheses in Table 4-1 designates the number of companies within the group identified that expressed a given point of view.

All companies currently committed exclusively to photovoltaic R\&D programs believed that this strategy is a worthwhile program. The greatest strength of the program according to these companies is that it is well suited to provide experience with

*For example, 10 companies representing all company groups said that Strategy 1 provides companies with useful systems experience. 


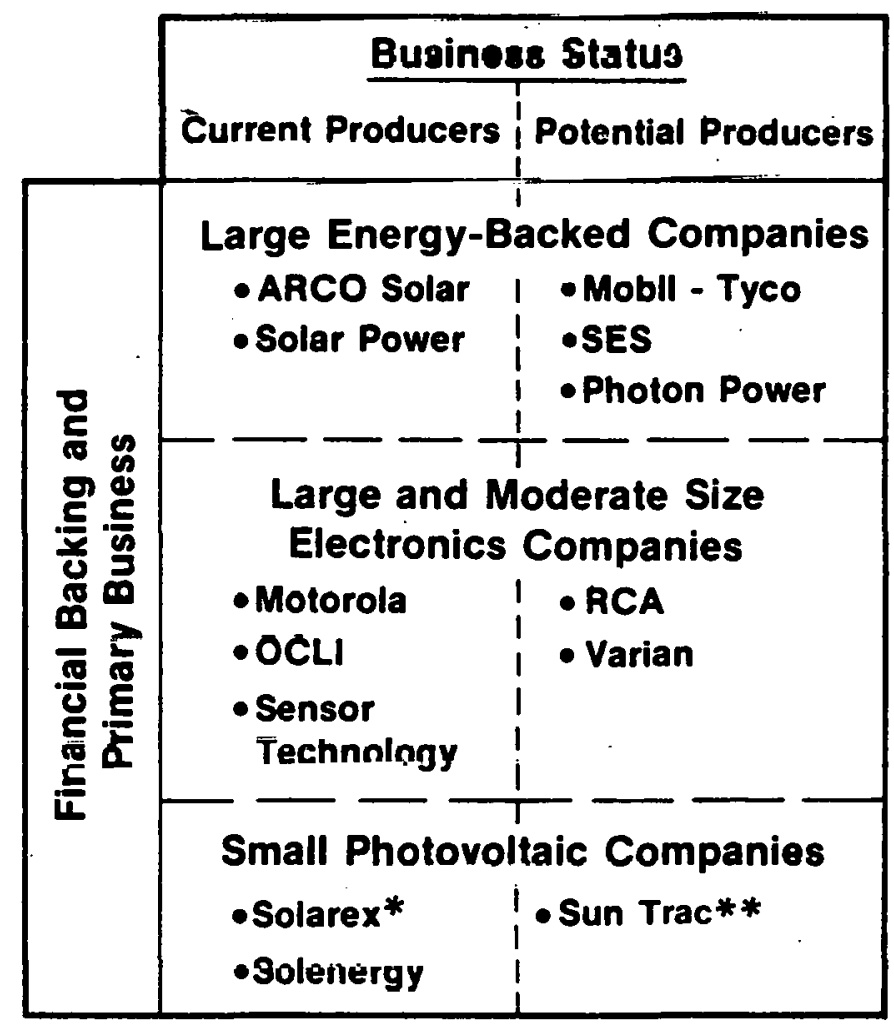

\section{PIgure 4-1. CATEGORIZATION UF COMPANY RESPONSES}

*This study was conducted prior to the announcement by Solarex of an investment by Standard Oil (Indiana). Solarex's responses are therefore grouped with those of small photovoltaic companies.

**Because Sun Trac is the only company in this category, responses of small photovoltaic companies are reported as a single group. Although Sun Trac has yet to enter commercial production, its production orientation makes its responses similar to small producing companies. 
complete photovoltaic systems. Companies thought that building systems experiments to improve system designs and monitor performance is the most appropriate objective of federal procurements. To realize this objective, contracts for the development and construction of complete systems are essential.

Table 4.1 RESPONSES TO STRATEGY 1: NO FIXED-PRICE, MODERATE BUDGET

\begin{tabular}{lc}
\hline \multicolumn{1}{c}{ Positive Features } & Company Groups $^{\mathbf{a}}$ \\
\hline Provides companies with useful systems experience & all groups (10) \\
$\begin{array}{l}\text { Permits diverse company participation and inclusion of diverse } \\
\text { technical approaches }\end{array}$ & all groups (13)
\end{tabular}

Problems

Provides little market stability; creates market uncertainty

all groups (6)

Funds likely to be concentrated in high-technology system companies with little commercial commitment to photovoltaics

Small companies lack sufficient systems expertise to participate

all groups (3)

$\mathbf{a}_{\text {Indicates the company groups that expressed the corresponding point. The number in }}$ parentheses designates the number of companies within the group identified that expressed a given point.

Several other positive features of this strategy were cited by $R \& D$ companies. Wide dispersion of numerous system contracts permits a large number of companies to gain experience with photovoltaic systems. Four R\&D companies are presently installing pilot facilities for the production of modules. They are eager to field some systems projects to see how their module performs, to obtain internal system design capabilities, and to gain experience and contact with potential users. Companies with new module technologies such as silicon ribbon, cadmium sulfide, and gallium arsenide concentrators felt confident that they would be able to participate in this program. These companies might be forced initially to sell their photovoltaic modules at below cost in order to be competitive with the single-crystal silicon modules sold by current producers. However, they would be capable of participating on a selective basis, thereby limiting the losses that would have to be absorher. These losses could be easily justified as investments to learn more about photovoltaic systems and markets.

If the systems funded under this program are well chosen, then the program could have a strong positive influence on the development of private markets. $R \& D$ companies stressed that there is little rationale to constructing systems that are already being sold commercially. Rather, efforts should be concentrated on designing standardized systems for use in U.S. energy markets such as residences and electric utilities, and also systems with intermediate market potential such as water pumps or village power systems. Several 
R\&D companies expressed concern that sufficient time and funds be provided in this program to support system design and development. These design costs were believed to be necessary to stimulate low-cost system approaches.

Five $R \& D$ companies interviewed, all of which have strong financial backing, stated that their future photovoltaic business plans would not be significantly affected if a systems test and application program similar to this strategy were not pursued or if for some reason they were not successful in participating in the program. However, they felt that this type of program was essential for facilitating future market acceptance. Federal support would begin to solve the problem of how to apply photovoltaics technology much earlier than if the industry is left to construct system projects exclusively with their own funds, But at the point at which theso companies become cunvinced that they have developed a cost-effective technology, they will invest their own resources to see that their products can be used. Federally funded projects will provide a head start. One small photovoltaic business felt that sales of modules in support of the tests and applications program were important to its future business viability.

Two points raised by $R \& D$ companies suggest why this strategy was not attractive to several current producers. First, the program provides little market stability and actually adds to market uncertainty. The short duration, small size, and wide dispersement of contracts under this program make it impossible for most companies to predict the government market in their production planning. Second, the magnitude of federal expenditures for application projects in the mid- and late-1980s is so small that government projects would have little effect on the industry by this timc.

Producing companies with an aggressive marketing and production orientation were most critical of this approach to federal procurements. Market uncertainty, as mentioned above, was described as their most serious problem. Purchases under this program wuuld do little to stimulate investments in module production facilities that could lead to lower costs. The major portion of the funds is likely to go to aerospace companies and systems contractors to pay for system design costs and balance of system components. Producers had little confidence in the commercial commitments to photovoltaics of these companies. The result would be high-cost, one-of-a-kind systems, with little money left over to spend on photovoltaic modules.

Two positive features similar to those mentioncd by potential producers were also mentioned by producing companies criticnl of the program. Thesc companies believed that it is important to involve many interested companies in federal procurements. Participation by numerous companies maintains a competitive industry and stimulates diverse technological approaches. Another positive aspect of the program is that it addresses photovoltaic systems as a complete package. Nearly all current photovoltaic producers see the photovoltaic business as a systems business and are anxious to gain experience with complete systems. However, a procurement approach that stimulates competition for federal funds with no corresponding commitment to commercial sales was viewed as nonproductive and not in the government's interest.

Three producing companies reacted positively to the approach of this strategy. Two of these companies, in which photovoltaics was a small portion of their electronics business, 
had perspectives similar to those of $R \& D$ companies described above. They saw little promise for reducing module costs through federal purchases and believed the primary objective of federal procurments should be to acquire systems experience and market information. One small photovoltaic company felt this is a good procurement strategy because the large number of contracts was likely to allow it to participate. This same company, however, and another small company were concerned that they did not have or expect to have the systems expertise needed to respond to the program.

Regardless of their opinion, all of the current producers indicated that they would participate in the program. The more aggressive companies were less concerned about the consequences of not participating than other companies, which saw these systems projects as an important element of their future business.

Pursuit of this moderate budget, no fixed-price systems procurement is likely to have the following effects on the photovoltaic industry. Numerous companies will participate in the program and the natural development of industry structure will not be altered. The production plans of photovoltaic companies, with the exception of very small companies, will not be changed by these federal procurements. Prices for photovoltaic modules will most likely follow the same trends that would have emerged without federal purchases. Many companies will gain systems and market experience with no company likely to receive a substantial market advantage. System costs may be reduced by the design and performance experience that results from this program. However, the prices paid by the government for systems procurred may be quite high because of the design costs and nonrecurring costs of prototype systems. In many instances, especially in early years, the prime contractor will be systems companies and not photovoltaic module producers. Balance of system costs and design costs will absorb a large portion of program dollars with a smaller share being spent on photovoltaic modules. Several module manufacturers stated that module prices in the PRDA program to date have been extremely competitive. Often, modules are offerred at cost or below cost to make an attractive systems proposal, presumably because proposal evaluations have emphasized module prices. The systems part of the project are typically more profitable. This pattern will motivate module manufacturers to develop internal systems capabilities in order to act as the prime contractor.

\subsection{INDUSTRY RESPONSES TO STRATEGY 2: FIXED-PRICE, MODERATE BUDGET}

Five current photovoltaic producers interviewed indicated that they would consider . bidding on this fixed-price procurement. Almost all of these, however, found some serious weaknesses in Strategy 2, and two companies would probably not bid without major modifications in the program. Three companies, two energy-backed subsidiaries, and one small business, stated that they would bid on the program. Even these three companies felt that several modifications in the strategy are necessary. None of the R\&D companies or potential producers interviewed would be likely to bid on this procurement.

Table 4-2 summarizes the positive features and problems of the fixed-price, moderate budget strategy identified by various company groups. The three producing companies 
most interested in this strategy found two features of the program especially attractive. First, the contracts are for a period of three years. A three-year contract would reduce the market uncertainty confronted by a company. This would encourage companies to make investments in improved production facilities as well as increase $R \& D$ to improve production techniques. The second attractive feature is the pressure exerted on module prices that is built into the program. These companies thought the price schedule outlined in the strategy $\left(\$ 5 / \mathrm{W}_{\mathrm{p}}\right.$ in FY81; $\$ 3 / \mathrm{W}_{\mathrm{p}}$ in $\mathrm{FY} 82 ; \$ 2.50 / \mathrm{W}_{\mathrm{p}}$ in FY83) is ambitious but achievable. A program that pushed companies to meet these prices could demonstrate that these prices are in fact possible. If these price levels proved to be unattainable, then both companies involved and the government would at least learn which prices are realistic.

Table 4-2. RESPONSES TO STRATEGY 2: FIXED-PRICE, MODERATE BUDGET

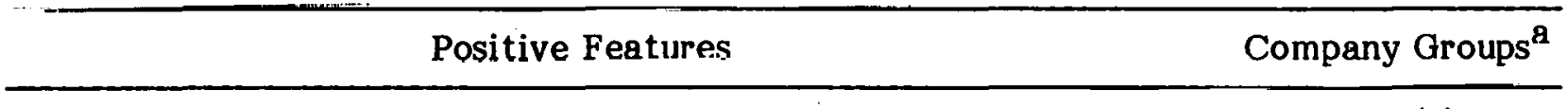

Three year contracts reduce market uncertainty, encourage production and $R \& D$ investments

Price targets apply healthy pressure on module prices

Contracts are large enough to enable companies to meet price targets

All groups (8)

- Large energy producers (2); small photovoltaic companies (1)

Large energy producers (1); small photovoltaic companiess (1)

Focus on modules is appropriate

Large energy producers (1); small photovoltaic companies (2)

Problems

Too few awards; too few companies; too few technical approaches

Price schedule not likely to be achievable; only companies with IItujor financial resources able to compete

Electronics producers (3); small photovoltaic companies (2); potential producers (6)

Companies winning contracts would achieve dominant industry position through early 1980 s

All groups (12)

Doesn't address system design and cost reduction problems

All groups (9)

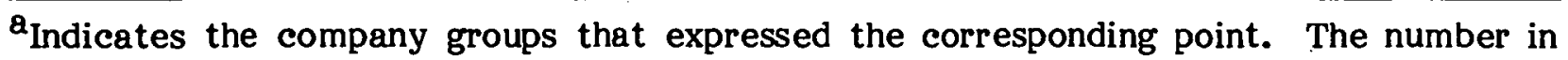
parentheses designates the number of companies within the group identified that expressed a given point. 
Two of the companies interested in bidding on this program believed that the $\$ 15-20$ million, three-year contracts for modules are of sufficient size to stimulate them to accelerate their investment plans and meet the terms of the program. The third company felt that the quantities of modules bought from any one contractor are too small to have any effect on its production plans.

These companies also differed over whether it is advisable to purchase modules separately and then issue a set of contracts for putting together photovoltaic systems. Two companies agreed with the separate module purchase approach of Strategy 2. Focusing on modules would provide more stability to the module company. Both of these companies, however, expressed a desire to participate in the systems contracts to gain systems and market experience. The third company stated that while the focus on modules in Strategy 2 applies pressure for module price reductions, this approach would result in expensive systems. Focusing on module prices ignores balance of system problems and the need to reduce the price of complete systems. All three of these companies stated that they expect to become suppliers of complete photovoltatic systems. They were concerned that some mechanism allowing for systems experience and addressing system design and cost be included in Strategy 2.

Several problems were articulated by the three companies most interested in this fixedprice procurement. All three agreed that government purchases should not exclude most companies involved in the photovoltaic industry. Strategy 2 would make it impossible for small businesses and numerous companies to participate if only four contracts were awarded. Government purchases serve as means of legitimizing producers and enhance their ability to make private sales. If a company is excluded from the government market, then it may have difficulties in making private market sales. One company said that at this stage in the photovoltaics industry, it is important to encourage a variety of companies with different technical approaches. Another concern expressed was that module performance and reliability need to be improved at the same time that prices are reduced. Some considerations should be given to performance and reliability as well as price in Strategy 2.

Two of the three companies likely to bid Strategy 2 implied that they would not invest in new production facilities or techniques to supply modules under this procurement. They would most likely expand and improve existing facilities, which produce single-crystal silicon modules. The third company indicated that it would build a semicrystalline silicon cell manufacturing facility to service the procurement. Construction of this facility is already part of the company's established plans.

Other producing companies interviewed were less enthusiastic about the desirability of the fixed-price procurement program outlined in Strategy 2. They were especially concerned about the small number of contracts awarded under this program, making it unlikely that they could receive any federal procurement contracts. If this were the only federal procurement program, then it would be impossible for these companies to be involved in any federally funded applications projects. These companies were also skeptical of the price schedule specified in Strategy 2. They felt that any company responding in 1981 would rely on single-crystal silicon cells. The current price of the basic raw material (i.e., polysilicon) makes the materials costs of cells approach or 
exceed the module prices specified. While it was recognized that several new polysilicon production processes are currently being developed, these processes were not believed to be producing low-cost material in time for use in this procurement program.

Producing companies unwilling to bid on this procurement believed that the risks of incurring losses would be substantial. Only companies with large financial resources would be able to absorb the losses likely to result from this type of program. Participation would therefore be limited to energy company subsidiaries or other large companies. All four producers who would not bid speculated that energy company subsidiaries are the companies that would most likely win contracts in this fixed-price procurement. In addition to access to large financial resources, energy companies can find other justifications for any losses that might result. For example, they could show a commitment to solar energy development to counteract claims that they are not investing profits in new energy sources.

If four companies were awarded multiyear contracts, these companies would assume a dominant position in the photovoltaics industry during the early 1980s and possibly longer. Three of the producing companies that would not bid said that their photovoltaic activities would be greatly reduced or abandoned if this program is pursued. A fourth producer stated that it would continue to sell photovoltaics in selected speciality markets. Nevertheless, this procurement would force a shake-out of current producers. Those companies that were awarded contracts, even if they were producing at costs above prices, would be given a strong marketing position. They would also be capable of making significant reductions in costs, though possibly not to the price levels shown in Table 3-2. Other producers would have difficulty establishing equivalent market positions and convincing their stockholders or boards of directors that further investments in production developments would yield reasonable returns.

Another problem with this program identified by some producing companies is that it must be designed for systems purchases rather than only modules and does not effectively address the problem of reducing systems costs. The reasons for this are similar to those expressed by producing companies who are likely to hid that were describcd abnve.

None of the companies interviewed conducting photovoltaics $R \& D$ would bid on this program. All of these potential producers stated that the price schedules in the threeyear, fixed-price procurement program are unrealistic. They said that if a company actually agreed to the contract terms of Strategy 2, it would inevitably experience losses. Prices offered would have little meaning and would not reflect true production costs. Several R\&D companies did not think that four companies would be willing to bid under the terms of this strategy and one company said it is unlikely that any company would bid on such a program. If companies did bid, these companies expected a number of escalation and exit clauses would be added to the contract to reduce the risks to bidding companies. For example; the government might have to guarantee the price and availability of polysilicon. All of the $R \& D$ companies thought that provisions for polysilicon prices or other clauses that reduce the risks of the program are not justified. They favor single-crystal silicon technology, and increase the probability that actual costs of production and private market prices will be higher than those that the program is supposed to achieve. 
Like current producers, $R \& D$ companies stated that the companies that could bid on this program would be limited to those with major financial backing and the ability to absorb losses. $R \& D$ companies also believed that companies that won contracts under Strategy 2 would achieve a dominant position in the photovoltaic industry in the near term, reducing industry competition. Four $\mathrm{R} \& \mathrm{D}$ companies, however, stated that this market advantage would be temporary. As other companies develop lower cost approaches, they could effectively compete with companies with more market experience; although the government program would make it more difficult. One $R \& D$ company said that a dominant position in the government market in the early 1980 s would have little relevance to private market developments later on.

Potential producers did not think that large procurements of this type would have a postive impact on photovoltaic technology. Single-crystal silicon cells are most likely to be bought. While some reductions in cost would result, major advances would not occur. Concentration of purchases in a few companies would make it impossible for R\&D companies with new module technologies to participate in federal applications projects. If separate contracts were let for modules and systems, few improvements in system design and cost probably would be achieved. Potential producers believed that use of separate systems contracts is a cumbersome approach that defeats one of the major objectives of procurements: developing industry systems design, marketing, and installation experience. Industry should be encouraged to seek their own solutions to the problem of building and selling cost-effective systems. Having the government coordinate module and systems contracts will limit this encouragement.

The following scenarios describe how pursuit of this fixed-price, three-year module procurement is likely to affect the development of the photovoltaic industry. First, only a few companies are likely to bid on this program; it is possible that no company will respond to the program unless modifications are made. The major uncertainty in bidding is whether module costs can be reduced to the $\$ 5 / \mathrm{w}_{\mathrm{p}}, \$ 3 / \mathrm{W}_{\mathrm{p}}$, and $\$ 2.50 / \mathrm{w}_{\mathrm{p}}$ prices in FY81, FY82, and FY83, respectively. Companies interested in bidding are confident that these prices can be achieved. These companies were also confident that these prices would be achieved without a government program of this nature. Two companies, however, thought that $\$ 15-20$ million, three-year module contracts would accelerate the realization of these prices. The third thought that a contract of this size would do little to accelerate its production plans and cost-reduction efforts.

Should companies bid for these contracts, they risk the possibility of incurring substantial losses. Well financed companies, particularly the oil-financed photovoltaic subsidiaries, are in the best position to risk any losses resulting from this program, because they are actively seeking investment opportunities in new energy sources. Nevertheless, one small business indicated it would seriously consider participating in a program of this type.

Single-crystal silicon modules will be the most common module technology used to supply purchases made. Production of single-crystal silicon modules has been the most extensive; costs are well understood; and sources for many further cost reductions are known to exist. Semicrystalline silicon cells, however, may be supplied by at least one company. This would represent the first production of semicrystalline silicon cells at a 
significant production rate, although these cells are likely to be produced even without this procurement program.

Numerous companies would be excluded from federal procurements because they are not willing or able to bid on a multiyear fixed-price contract such as Strategy 2. Elimination of the opportunity to gain systems and market experience through federal applications programs and lack of opportunities in the federal market is likely to discourage the activities of several photovoltaic companies. Companies awarded contracts could acquire a dominant position in photovoltaic sales in private markets in the early 1980 s. Their prices to private markets probably would be higher than prices to the government, but sufficiently below the costs faced by other companies. Price pressure would limit the sales of other producers to specialty markets willing to pay higher prices. This competition could discourage some producing companies to the extent that they would leave the photovoltaic business. Most of the R\&D companies interviewed, however, are committed to continuing their $R \& \bar{D}$ programs. These companies believe that if they can develop a superior, lower-cost photovoltaic module, then they will be well equipped to challenge the position of the early industry leaders. Several R\&D companies believed that they may even be in a better position than companies receiving large government procurement contracts. This is because companies receiving contracts would be preoccupied with trying to respond to contract terms, while the $R \& D$ companies could devote their talent and resources to technology and production improvements that would ultimately lead to even lower costs. Inability to participate in government application projects could slow the rate at which $R \& D$ companies will learn how to design and market photovoltaic systems. But they will gain this exporience eventually. Onc R\&D company would possibly abandon its photovoltaics activities for lack of government application projects support.

At the end of this three-year fixed-price procurement in FY83, the number of companies producing and selling photovoltaic modules probably will be fewer than the number of producers today. Cost reductions will have been realized by companies awarded contracts, but costs might remain above the prices at which modules are sold to the government. Companies presently committed to $R \& D$ also will have made cost reductions, and may enter production with lower cost approaches. Thus, the early shake out of producers may prove to be only temporary.

Several modifications were suggested that could make Strategy 2 more appealing. All companies interviewed thought that the number of contracts awarded should be increased. Several different approaches were discussed. One idea would be to have companies bid multiple quantity and price schedules for each year of the program. A ratio system could then be used to make awards. Companies with lower price bids would receive contracts for larger quantities. All qualified companies would receive at least a small contract but companies that are capable of bidding lower prices would be encouraged to make investments to realize lower costs. Through this approach, producers with lower production costs would be rewarded but other producers, small businesses, and companies with new module concepts would not be excluded from federal procurements.

Another modification suggested by three companies would be for the government to focus purchases on long-term price goals as opposed to the intermediate prices specified 
in Strategy 2. These companies suggested that the government could purchase large quantities of modules from any company at prices below $\$ 1 / \mathrm{W}_{\mathrm{p}}$. While no company is likely to meet these price levels for several years, this visible commitment would motivate companies to reduce costs to this price range.

At least one company believes there is a need to insure that companies receiving contracts under Strategy 2 are not selling modules at prices below costs. This company states that the function of the program should be to stimulate real reductions in costs, not to encourage companies to buy market position or production experience, particularly if that position reduces the participation of other companies. Thus, if the prices resulting from the program do not reflect costs, then the change in industry structure and advantages given to selected companies would have achieved little. This company suggested that a mechanism to audit the costs of contractors should be developed to prohibit selling at below costs. This company also stated it is important that companies receiving contracts have a commercial commitment to the photovoltaic business. Otherwise, companies primarily interested in soliciting government contracts would be supported with little positive effects on photovoltaics industry development.

It was also suggested that some mechanism needs to be found to address the problem of designing lower-cost systems. One possibility attractive to several companies was to award multiyear contracts to design and install standardized systems for selected applications. The feasibility of using fixed-price contracts for the systems is unclear because of uncertainties in system designs and costs. Two companies felt that it is impossible to simultaneously pressure cost reductions and obtain needed information on photovoltaic systems. The requirements for a program with both of these objectives are contradictory: one calls for volume and standardized designs and the other for experiment and design innovations.

Another modification suggested was the need for a more equitable price comparison measure than dollars per peak watt. At a minimum, some consideration of performance, reliability, lifetime, and total system cost is essential.

Delaying the start of this program until FY83 could change company attitudes. Producing companies interested in bidding stated that by FY83 the quantities purchased by the federal government would be too small to have an impact. $R \& D$ companies and other producers believed that by FY83, much more will be known about the costs of various production techniques. The changes in industry structure encouraged by this procurement would therefore be less extreme.

\subsection{INDUSTRY RESPONSES TO STRATEGY 3: FIXED-PRICE, AGGRESSIVE BUDGET}

Only a brief discussion of the fixed-price, aggressive strategy is presented here. With few exceptions, comments regarding this strategy were identical to the comments on the fixed-price, moderate budget strategy. This summary is limited to those comments unique to Strategy 3. Positive features and problems are described in Table 4-3. 
Table 4-3. RESPONSES TO STRATEGY 3: FIXED-PRICE, AGGRESSIVE BUDGET

\begin{tabular}{ll}
\hline \multicolumn{1}{c}{ Positive Features } & Company Groups \\
\hline $\begin{array}{l}\text { Budget, contract dollar value are large enough to affect busi- } \\
\text { ness plans of aggresssive producers }\end{array}$ & $\begin{array}{l}\text { Large energy pro- } \\
\text { ducers (1) }\end{array}$ \\
\hline \multicolumn{1}{c}{ Problems } & All groups (13) \\
\hline $\begin{array}{l}\text { Five year contracts are too long } \\
\text { Price targets, delivery schedules not credible }\end{array}$ & All groups (12) \\
$\begin{array}{l}\text { Other problems similar to those of the fixed-price, moderate } \\
\text { uudget strategy }\end{array}$ & See Table 4-2 \\
\hline
\end{tabular}

${ }^{a_{I}}$ Indeates the company groups that expressed the corresponding point. The number in parentheses designatos the number of companies within the grvup identifled lhat expressed a given point.

None of the companies interviewed indicated that they would be willing to bid on this program. There are two reasons for this. First, a five-year contract is too long for photovoltaic producers. Technical and market uncertainties during the next five years are likely to dominate the photovoltaic industry. No company is comfortable with production commitments for five years. While three-year contracts were attractive to many companies because of reduced market uncertainty, the five-year commitment is apparently long enough to raise technological uncertainties that overshadow the reduction in market uncertainties. The second reason that companies would not bid on this program is that the prices and delivery schedules are not credible. All of those companies skeptical of the price schedule in Strategy 2 were even more skeptical of the price schedule in Strategy 3. Of the three companies interested in bidding on Strategy 2, two companies felt that the price schedule was not possible, particularly for achieving $\$ 5 / \mathrm{W}_{\mathrm{p}}$ in FY80. These companies also felt that $\$ 15-20$ million contracts were large enough to stimulate production improvements and cost reductions. Larger contracts would result in little additional progress at great expense. One company interested in bidding on Strategy 2, however, believed that the $\$ 40$ million contract in Strategy 3 was beginning. to approach the level at which their current business plans would be accelerated.

\subsection{INDUSTRY RESPONSES TO STRATEGY 4: EXPERIMENTAL PRODUCTION FA- CILITY SUBSIDIES AND FIXED-PRICE BUYS}

Table 4-4 summarizes comments on the experimental production facility subsidies and fixed-price buy strategy made by different company groups. Four companies interviewed thought the combination of subsidies for the installation of pilot production facilities followed by small government module purchases is a good approach. Three of these companies are electronics companies currently producing photovoltaics. The fourth is an energy-backed subsidiary conducting $R \& D$ on a new module technology. Several reasons were given for this strategy's appeal. One reason is that government expenditures are directed at the source of potential cost reductions, improved production techniques. 
Rather than attempt to purchase large quantities of modules or systems to indirectly stimulate companies to invest in new production techniques and facilities, these improvements can be more easily achieved by directly supporting the new techniques and facilities themselves. Favorable companies also believed that support for pilot facilities would encourage them to accelerate their development plans. Also, the government obtains much more credible cost information by facility, funding than by large procurements. The government would be able to check costs of production with information made available on the operation of the pilot plant. In procurements, the only indication that the government has of costs is prices, which do not necessarily reflect actual costs.

Table 4-4. RESPONSES TO STRATEGY 4: EXPERIMENTAL PRODUCTION FACILITY SUBSIDIES AND FIXED-PRICE BUYS

\begin{tabular}{lll}
\hline & Positive Features & Company Groups $^{\mathbf{a}}$ \\
\hline
\end{tabular}

Provides direct support of improved production techniques and facilities

Electronics producers (3); large energy potential producers (1)

Module cost information could be validated by government

Electronics producers (3); large energy potential producers (1)

Problems

Requirements for public disclosure of proprietary technical data would discourage most companies from participating Companies with real production advances should be able to obtain private capital

Difficult to evaluate proposals

Gives unfair advantage to a few companies
All groups (7)

Large energy producers (1); large energy potential producers (2); potential electronics producers (2); small photovoltaic companies (1)

Large energy producers (1); large energy potential producers (1); small photovoltaic companies (1)

Large energy producers (1); large energy potential producers (1); small photovoltaic companies (1)

\footnotetext{
andicates the company groups that expressed the corresponding point. The number in parentheses designates the number of companies within the group that expressed a given point.
} 
One company commented that more than four contracts would need to be funded in order not to give a few companies an unfair advantage. This same company, plus two other companies that liked the facility subsidy concept, felt strongly that, while economic and cost information on plant operation would be publicly available, under no circumstances would they be willing to divulge proprietary technical information on their production processes. If it was required that technical information be made available to the government, even these three companies would not participate.

The fourth favorable company was apparently much less concerned with maintaining a proprietary technical position or did not consider the potential problems of such a requirement. This company suggested that it would be useful to assemble all of the various subprocesses being developed under federal support into one pilot production facility to demonstrate lower costs,

Other companies interviewed were much less favorable toward the facility subsidy approach. This group consisted of both electronics and energy company potential producers, current producers, energy-backed producers, and small photovoltaics companies. Both large and small companies objected to this strategy. A major criticism was that if a new production process was available, then a company would have little difficulty attracting venture capital to finance a pilot facility. A proprietary technical position, however, is needed to attract private funding. One company stated that the information requirements of this program would preclude a participating company from raising private venture capital. Several companies said that it would be very difficult to evaluate and select proposals under this program. Aerospace and major government contractors with good proposal preparation skills are likely to be attracted; the commercial promise of ideas proposed was thought to be limited. Companies also objected to giving facility subsidies to a small subset of the industry. Selected facility contracts would give a few companies an advantage that would be difficult to justify.

The results of pursuing this facility subsidy and fixed-price buy program are ambiguous. The majority of companies did not believe this program would accomplish much that would not be accomplished by the private sector without government support. A few companies felt that this program could generate useful information on the operation of module production facilities, particularly information on prodiction costs. No company, however, claimed that his program would greatly accelerate their entry into pilot production at the time that they are convinced that the experience and information gained from a pilot facility would enhance their development program. Two companies favorable to the program indicated that they already plan to invest in pilot production facilities for new module technologies during the FY81-FY84 period. The government program would help these companies defray some of the costs of activities that are already planned.

\subsection{INDUSTRY RESPONSES TO STRATEGY 5: INNOVATIVE PRODUCT PRO- CUREMENT}

As shown in Table 4-5, responses to Strategy 5 were divided into two groups. One group thought small purchases of innovative products would be a useful addition to any 
government procurement strategy. The other group felt that it would be impossible to fairly evaluate proposals that promise potential cost reductions, making the program unworkable.

Table 4-5. RESPONSES TO STRATEGY 5: INNOVATIVE PRODUCT PROCUREMENT

Positive Features $\quad$ Company Groups $^{\mathbf{a}}$

Complements other strategies

Large energy producers (1); large energy potential producers (1); electronics producers (3); electronics potential producers (1)

Early production experience with new module techsame as above nologies essential to understanding of production economies

Three-year contracts are helpful

same as above

Problems

Impossible to effectively implement

Large energy potential producers (2); small photovoltaic companies (2)

"Potential" for cost reduction difficult to evaluate

Large energy potential producers (2); small photovoltaic companies (2)

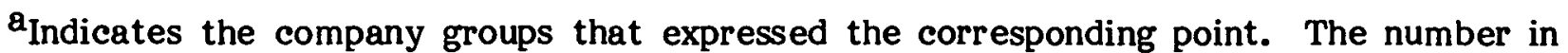
parentheses designates the number of companies within the group identified that expressed a given point.

Six companies thought the innovative product procurement outlined in Strategy 5 is a good program. Favorable companies included a diverse group: one energy company subsidiary currently pröducing modules; one energy company subsidiary not yet entering production; three electronics firms currently producing modules; one electronics potential producer; and one small business producer. These companies stated that early production experiences with new module technologies is essential to understanding how to economically produce modules. This program would help companies gain this experience and stimulate the process related to $R \& D$. Three-year contracts were believed to be especially helpful. Early emphasis on experimenting with production of new module concepts could lead to lower module prices in the long term. Although companies favorable to this program acknowledged that evaluating proposals would be difficult, they felt acceptable evaluation criteria and a fair selection could be devised.

Companies that did not think this was a workable program included two energy subsidiary research companies and two small photovoltaic businesses. None of these companies 
disputed the value of early production experience with new module technologies. However, they felt the program would be impossible to effectively implement. They were especially suspicious of evaluating cost reduction potential. If cost reduction potential could not be shown for an innovative module, then a company would not be interested in the concept. Separating real cost reduction potential from promised potential is an impossible task. A few companies also believed that this program was likely to attract poor quality concepts that are unable to gain private support.

This program, if pursued as an addition to some type of systems applications program, could stimulate companies to experiment with techniques for producing innovative modules. This support for new technologies could increase private R\&D funds devoted to module production experiments, and ultimately could lead to lower module prices in the long term. The program could also cause considerable debate within the photovoltaics industry concerning which concepts are viable and which are not. 


\section{SECTION 5.0}

\section{COMPARISON AND DISCUSSION OF INTERVIEW RESULTS}

This section begins by comparing the company responses to the procurement strategies with regard to four issues that were emphasized in the interviews and that are believed to be especially important in anticipating the supply effects of a planned program. These issues are: the types of companies likely to bid on different programs; the effects of the strategies on industry competition; the impacts of each strategy on private production and $R \& D$ investments; and the impacts of the strategies on system and module costs and prices. Following the comparison of results on these issues, other issues that were raised in the interviews are discussed. Resolution of these issues, while receiving less attention in the interviews than those mentioned above, is also likely to be critical to the design of a successful procurement program.

\subsection{COMPARISON OF RESULTS}

\subsubsection{Companies Likely to Bid}

One of the most interesting and important results of the interviews was that whereas all companies would be likely to bid on the no fixed-price, moderate budget strategy, only a few companies would consider bidding the fixed-price, moderate budget strategy. Probably no company would bid on the fixed-price, aggressive budget strategy. Table 5-1 summarizes the bidding positions of the companies in relation to each of the five strategies.

Table 5-1. COMPANIES LIKELY TO BID ON ALTERNATIVE PROCUREMENT STRATEGIES

Strategy 1: No Fixed-Price, Moderate Budget

All companies interviewed are likely to participate in this program.

Strategy 2: Fixed-Price, Moderate Budget

Five current producers would consider bids; only three of these (two energy company subsidiaries; one small business) are likely to bid

Strategy 3: Fixed-Price, Aggressive Budget

No company is likely to bid.

Strategy 4: Experimental Production Facilities and Fixed-Price Buys

Four companies (three electronics producers; one energy company subsidiary) would consider bids if no requirements for disclosure of technical information are made. Only one would bid if disclosure is required.

Strutegy 5: Iimovative Product Procurement

Undetermined. It is likely that several current producers and potential producers with new production techniques would bid. 
All companies are likely to bid on the no fixed-price, moderate budget strategy because the large number of small contracts awarded under this program permits diverse participation. Small contracts also allow companies with limited financial resources or limited production commitments to participate in government application projects at a modest level.

The large contracts, limited number of awards, and declining price targets stipulated under the fixed price, moderate budget strategy (Strategy 2) severely limit the number and type of companies that would bid on this program. Whereas five companies indicated that they would consider bidding, only three stated that they are likely to bid. This is even less than the four contracts which were specified as the anticipated number of contracts under this program. The companies unwilling to hid on this program believed that the price targets would not be met, therefore requiring a company bidding on a contract at a fixed price to be prepared to absorb potentially large losses.

The fixed-price, aggressive strategy was so intimidating to all companies interviewed that no company expressed an interest in bidding the program. The five year contract and extremely aggressive price targets make this strategy unappealing to even those companies with confidence in major module price reductions.

The experimental production facility strategy interested four firms, as long as information disclosure requirements were kept to a minimum. Several firms expressed interest in the innovative product procurement strategy. The exact number of companies that might bid that type of program was not determined.

The existing photovoltaic program procurement techniques, which most closely follow those of Strategy 1, appear to encourage a large number of companies to participate. Attempts to introduce larger contracts and fixed-price contract terms tied to lower. photovoltaic modules prices will limit the number and type of companies that will participate. Production facility subsidies are of interest to only a small group of companies. Many companies are likely to respond to a procurement strategy that emphasizes new module production technologies.

\subsubsection{Impacts on Industry Competition}

Table 5-2 summarizes the likely effects of the five procurement strategies on industry competition. Here, competition is defined as the number of firms actively producing and marketing photovoltaics and the relative positions that these firms hold. A competitive industry is one with many active firms and with no single company or group of companies dominating the industry.

Strategy 1, because it involves many different companies, is likely to encourage increased industry competition. Diverse participation in federal application projects will probably stimulate companies to pursue private markets as well.

The fixed-price, moderate budget strategy could substantially reduce industry competition through the early 1980s. Only a few firms are likely to participate in this program. 
No matter what the actual costs that will be faced by these firms are, they can be expected to lead the industry in sales both to government and private markets. The exclusion of other firms from the government market is self-evident. Companies receiving government contracts under this program are likely to enjoy private market advantages due to the visibility and experience resulting from the government program.

Table 5-2. IMPACTS OF ALTERNATIVE STRATEGIES ON INDUSTRY COMPETITION

Strategy 1: No Fixed-Price, Moderate Budget

Slightly encourages industry competition. Offers little market advantage to any one company.

Strategy 2: Fixed-Price, Moderate Budget

Reduces industry competition through early 1980s by giving participating companies significant market advantages. Long term impacts are uncertain.

Strategy 3: Fixed-Price, Aggressive Budget

No effect because no company is likely to participate.

Strategy 4: Experimental Production Facilities and Fixed-Price Buys

Gives companies receiving production facility subsidies slight market advantage by lowering production costs.

Strategy 5: Innovative Product Procurement

Could encourage competition by stimulating companies with new production technologies to enter production.

In the middle 1980s, the positions of dominant producing companies could be challenged by other companies that have achieved major production improvements. These companies may have an easy or difficult time challenging dominant producers, depending on the extent of their price reductions and the strength of the market power of companies dominating production in the early 1980 s.

The aggressive fixed-price strategy will not likely affect industry competition because no companies would participate in this program.

Slight competitive advantages are given to participating companies in the experimental production facilities program. These advantages would be manifested in lower production costs, which are llkely to be short lived.

The innovative product procurement could increase industry competition by encouraging companies with new module production technologies to enter production earlier than they might on their own. The degree of acceleration of production plans stimulated by the innovative product procurement was not determined. 


\subsubsection{Impacts on Private Production and R\&D Investments}

As shown in Table 5-3, the no fixed-price, moderate budget strategy would not influence the production and $R \& D$ investment plans of well-financed companies.' Smaller companies, however, are more dependent on constructing application projects under government support. It is possible that participation in this program would be essential to future investments by a few small companies.

Table 5-3. IMPACTS OF ALTERNATIVE PROCUREMENT STRATEGIES ON PRIVATE PRODUCTION AND R\&D INVESTMENTS

Strategy 1: No Fixed-Price, Moderate Budget

Plans of both well financed production and $R \& D$ companies would not be significantly changed. Production investments of small companies would be enhanced.

Strategy 2: Fixed-Price, Moderate Budget

Bidding companies that receive contracts would expand and accelerate already planned investments. Photovoltaic activities of producing companies not receiving contracts would be significantly reduced. $R \& D$ companies would first reevaluate their $R \& D$ commitment. Most indicated they would probably maintain commitments to existing $R \& D$ programs and challenge producers when they have achieved clear cost advantage.

Strategy 3: Fixed-Price, Aggressive Budget

No Impacts because no company would bid strategy.

Strategy 4: Experimental Production Facilities and Fixed-Price Buys

A few s:m[nнnies with existing plans for investments in production cquipment would be certain to make these investments if awarded contracts.

Strategy 5: Innovative Product Procurement

Could stimulate companies to make early investments in production experiments for new module production processes.

The fixed-price, moderate budget strategy will accelerate the production investments of companies receiving contracts. These investments will be essential to meet the required production and price schedules. Some producing companies that do not participate in this program are likely to reduce or limit additional production investments. Most $R \& D$ companies, however, are expected to maintain their existing commitments to further $R \& D$ investments, although they are likely to reevaluate their commitments.

The investment impacts of the other strategies are likely to be more limited. Strategy 3 will have no effects given that no company would participate. The production facility strategy might ensure that currently planned investments of some companies are in fact pursued, perhaps on a faster schedule. This strategy is unlikely to change any company's plans significantly. The same pattern is seen for the innovative product procurement, Strategy 5. 


\subsubsection{Impacts on System and Module Costs and Prices}

Table 5-4 summarizes the likely impacts of the five strategies on system and module costs and prices. Strategy 2 would have the most direct effects on module costs and prices. As discussed previously, it is uncertain whether the price targets specified in the fixed price contract under Strategy 2 would be achieved. Strategy 1, with its emphasis on systems, could help reduce system costs. The innovative product procurement could help reduce module prices in the long term, but its effects are speculative. The other strategies are unlikely to have significant effects.

Table 5-4. IMPACTS OF ALTERNATTVE PROCUREMENT STRATEGIES ON SYSTEM AND MODULE COSTS AND PRICES

Strategy 1: No Fixed-Price, Moderate Budget

Module costs and prices are not likely to be affected. System costs may be indirectly reduced through design and performance experience.

Strategy'2: Fixed-Price, Moderate Budget

Module cost reductions likely to be achieved by participating companies, but may remain above prices required in the contracts.

Strategy 3: Fixed-Price, Aggressive Budget

No impacts because no company would bid.

Strategy 4: Experimental Production Facilities and Fixed Price Buys

Unclear, minimal short-term impacts.

Strategy 5: Innovative Product Procurement

Could lead to lower module prices in the long term by encouraging development of new production techniques.

\subsection{OTHER ISSURS RAISED IN INTERVIEWS}

In addition to the issues discussed above, several other issues critical to the design of an effective procurement program were raised in the company interviews. These issues range from defining the objectives of the procurement to the details of the evaluation critcria that will be used in making awards. Along with the issues discussed above, these issues provide a useful checklist of considerations in developing a photovoltaic procurement strategy as part of the national photovoltaic program sponsored by DOE.

\subsubsection{Objectives of the Procurement}

A major concern of the photovoltaic industry is the government's objective in purchasing photovoltaic systems. The overall objectives of the national photovoltaic program are well known to the industry and have not been discussed. However, at least three alternative objectives for the federal procurements were identified by the companies interviewed. Each of these suggests a somewhat different procurement approach. 
First, a procurement can be undertaken to obtain performance and market information about various systems before they become economically feasible on a large scale. The industry is interested in participating in such tests to get first-hand information for its own engineering and marketing strategies. In fact, a few companies are supporting such tests with internal funds. Application projects relevant to international markets are currently of most interest.

A second objective of a procurement could be to help industry obtain production development and scale-up experience that would accelerate cost reductions. One company stated this objective as an attempt by the government to change the industry's business plans. The schedules for installing improved production equipment, setting up pilot production facillties, or mechanizing current production lines would be accelerated if the procurement is successful.

A third objective could be to increase photovoltaic system production capacity as rapidly as possible. This expansion would lead to cost reduction if it is assumed that there is a strong correlation between output volume and price. However, the expansion of U.S. production capacity could be an objective even if it leads to only minor cost reduction. This capacity could be used as insurance to serve U.S. needs if energy problems become more severe. The second and third objectives differ in that the latter objective stresses the expansion of capacity and the former stresses advances in production developments with modest production capacity expansion.

The interviews did not suggest clearly which of the three objectives is most appropriate. However, two points were stressed in the discussions. First, helping the industry obtain technical and market information is an important and appropiriule government objective. Therefore, mechanisms to obtain this information should be an element of any procurement program chosen. Second, many (although not all) of the interviewees emphasized that photovoltaic cost reductions do not result merely from expanding existing production capabilities. What is required is production improvements to complete key production steps faster and at lower costs. Many of the companies visited were investing significant resources to overcome these problems. When government purchase volumes were raised, the usual response was that the higher volumes would be met by adding production shifts or installing a second piece of production equipment at a key bottleneck in the line.

\subsubsection{Evaluation Criteria}

The criteria to be used for the award of procurement contracts will be critical to the success of the program. For example, a procurement award based on the potential for cost reduction (as in the innovative product procurement; Strategy 5) may not be successful because contracts could be awarded for good proposals, but not necessarily for good concepts. Many of the current producers went on to assert that most evaluation criteria used today strongly favor companies with proposal preparation capabilities rather than a knowledge and commitment to photovoltaic technology. 
Fixed-price procurements by their nature focus on prices as the primary evaluation criteria. This may be a valid approach if prices are an accurate reflection of costs, and if the emphasis on lowest prices in the short-term does not have adverse effects on longer-term prices. Using price as the primary evaluation criterion may also influence industry competition by encouraging those companies with aggressive short-term pricing policies and production plans and discouraging less-aggressive companies. As discussed previously, price pressure is typically more acceptable to larger companies with substantial financial resources. Smaller, less well-financed companies are likely to be at a disadvantage in the federal market if prices alone are the evaluation criteria used in making awards.

In light of some of the problems associated with the fixed-price approach examined in this study, it would be more desirable to design a procurement that encourages cost reductions but does not simultaneously alter the structure of the industry or discourage longer-term technologies.

An alternative method of evaluation of large fixed-price contracts concentrated in a few firms was forwarded by several companies. It was suggested that firms be given the opportunity to provide sealed bids that outline a price schedule combined with a schedule of delivering either modules or systems. Contract awards would be based on those price/quantity bids. Firms bidding the lowest prices would get the largest percentage of the available funds. The maximum size of a bid from any one company would have to be limited to some portion (probably 25-30\%) of the total procurement funding. Other firms would get the remainder of the procurement based on a relative ranking of their price/quantity bids. Therefore, awards could be received by firms that bid prices higher than the low bidder but deliver only kilowatts instead of megawatts.

This evaluation method appealed to the industry for a number of reasons. It allows more awards than would be possible under the fixed-price, fixed-quantity strategy and thus prevents premature elimination of firms that were not awarded contracts. It also allows firms to bid prices that reflect actual costs of production, without fear of being completely excluded from federal procurements. This would allow a company with a new, but still relatively expensive module to participate at a modest level in the program. New entrants without the financial resources for immediate aggressive pricing could also participate. However, incentives for price competition would still exist because lowerprice bids result in larger contracts. Finally, it gives firms more flexibility to fit their bids into their production development and expansion plans.

One problem with this evaluation method is that it does not provide an obvious mechanism to eliminate a bidder from receiving an award. One way around this problem is to prepare a qualified bidder's list of module producers based on past production experience, delivery records on DOE purchases, module reliability, performance, or other measures of commercial commitment to the technology. Any company then could enter the competition for the system contracts. However, they would be required to team with one of the qualified module companies. This approach could have a tendency to bias procurements to the existing photovoltaic industry unless some means of demonstrating commercial commitment other than past production is devised. 
Another concern of the industry is the unit of measure used to evaluate module prices. If only modules are purchased in the procurement, low-efficiency, nonconcentrating systems probably would be favored, because no compensation would be allowed for a lower balance of system, land, and installation costs associated with higher-efficiency or concentrating modules. In addition, the term "dollars-per-peak-watt" as a means of expressing module prices becomes very confusing when dealing with concentrators. A more valid comparison of module prices is price per unit of power ( $\mathrm{kWh}$ ) delivered from complete systems over their entire lifetime, although $\mathrm{kWh}$ costs require energy assumptions to compute.

All the companies interviewed mentioned that the performance and reliability of systems are equally as important as prices. Tradeoffs between price and quality will be different across applications. If the procurement is to help stimulate production of systems relevant to particular applications, these tradeoffs have to be recognized in the evaluation criteria.

\subsubsection{Contract Size}

The dollar size of the government contract with a producer could have a major impact on his decision to invest in production facilities. Most producers agreed that short contracts of less than $\$ 1$ million would be considered single orders of insufficient size to influence current business plans. Larger contracts lasting up to three years could influence production plans. Some of the silicon photovoltaic producers felt that three-year contracts of \$15-20 million would be sufficient to stimulate investment. One firm apparently has plans that call for much larger investments than most other firms. They would require contracts in the range of $\$ 80-100$ million to stimulate more production investment than their current plans. Companies with this attitude see large government procurements as a means of selling some of their planned production output. They view the procurement as a sale that would be an interesting but not a decisive element of their expansion. At the other end of the spectrum, some smaller firms felt unsure that they could manage large contracts and produce the quantities necessary within the required schedule.

\subsubsection{Contract Duration}

One of the more surprising results of the interviews was a reluctance of the industry to accept contracts lasting five years. Most felt that the technology was evolving too rapidly to commit to prices and deliveries five years in advance. Certainly the industry would not commit to a particular production technique over that period. Many of the interviewees pointed out that a multiyear commitment to output does not mean that production developments would cease or the production technology would not change. In fact, requirements for price reductions might stimulate such production changes. Therefore, one cannot conclude that five-year contracts are not desirable because they commit firms to a single production technology. 
The risks of a five-year contract would fall into two categories. First, supplies and prices of raw materials are too uncertain to bid fixed prices over five years. Second, a fiveyear contract might amplify mistakes in price prediction that could not be carried as losses. As the length of time over which the price is predicted increases, the potential for error and major losses also increases. Most firms would not accept the risk of potential loss over a five-year period.

Contracts lasting three years were generally viewed as sufficiently extended to reduce sales uncertainty without the extra risks of predicting prices farther into the future. Three-year contracts for purchase of innovative module technologies were also regarded as desirable. One-year government contracts or single-purchase contracts tend to add to the uncertainty of yearly demand because the magnitude and timing of such sales cannot be predicted. The uncertainty of government funding and the evaluation criteria used by the government make government sales harder for firms to plan for than commercial sales.

\subsubsection{Escalation and Exit Clauses}

Multiyear contracts can transfer risks of failure from the government to the private sector only if escalation and exit clauses of the contracts are properly designed. The interviewees gave varied responses to the need for escalation clauses. Two firms said that they did not need any escalation clauses contingent on the price of polysilicon. This attitude appears to stem from the fact that one firm had a stockpile of polysilicon at its disposal and significant financial backing. The other had plans to integrate its production backwards into the production of polysilicon, thereby gaining more control over the price.

Smaller firms without large amounts of financial resources have little ability to absorb losses associated with rising input prices. These firms wanted escalation clauses covering polysilicon, labor, and other specific input materials used in the production of modules and systems.

Almost all of the firms interviewed wanted an escape clause for the multiyear contracts. A mechanism to allow the contractor to terminate the contract is needed if losses become excessive or if a corporate decision is made to leave the photovoltaic industry.

Another important clause of the contract would be a penalty for missing delivery dates. The technology is evolving very rapidly and costs are declining quickly. Late deliveries give a company a significant opportunity to lower costs or produce the necessary quantities of modules without expanding capacity. The importance of meeting delivery dates should be stressed by applying severe penalties (e.g., cancellation of the contract). Small firms felt particularly sensitive to strong exit or late delivery penalties. Small firms have the least ability to absorb monetary contract penalties. Those clauses favor firms that can best bear these costs. 


\subsubsection{Module vs. System Purchases}

The issue of procuring complete systems or purchasing only modules with separate contracts for systems has received considerable attention. The companies interviewed saw strengths and weaknesses with both approaches.

Module contracts have some appeal because producers can focus on cost reduction of modules, the most significant system components in terms of cost and production development needs. Module procurements also would help standardize module specifications and sizes by having significant sales of the same module configuration. Module contracts were also viewed as helpful to producers who are not interested in expanding to become system suppliers.

System contracts have advantages in that they help the industry develop capabilities to serve commercial needs, not merely supply components. Second, they allow contractors the flexibility to make cost reduction tradeoffs in all parts of the system. Third, system procurements can be designed to allow direct customer-producer contacts. Finally, these procurements will give suppliers operating data for use in future product improvements.

One of the problems of procuring systems rather than modules is that the systems have to be chosen before the contracts begin. All of the producers agreed that the government should not purchase systems or modules that would be used in existing costeffective applications. At least one company saw cost-effective federal applications as one of the markets that should not be served by a central multiyear procurement. Other companies felt that federal facilities are a prime target for a centralized system procurement, but these purchases should not substitute for other federally funded applications projects.

All companies interviewed felt that purchased hardware should be used in three types of applications: internationally oriented pumping, multi-use village power, and dispersed residential systems. Central station utility systems are the farthest from commercial viability and probably should not be purchased. This agreement on appropriate applications suggests a structure for multiyear systems procurements. According to the industry, a firm should be given an opportunity to bid on the production of numerous systems that serve one or more of the three applications. The contract would give production and design experience in systems that have significant commercial potential. Alternative designs for these applications can be viewed and compared. Such comparisons add another element of competition to the program and allow the entire industry to benefit from the design mistakes of individual companies.

\subsubsection{Program Timing and Technologies Favored}

One of the key issues that must be addressed by federal decision makers concerns which photovoltaic technologies are favored under the various procurement options. The interviews conducted suggest that if a major multiyear procurement begins early (i.e., FY80) and delivery dates are for 1980 or 1981 , only existing production capabilities will be 
used. Under this scenario, single-crystal silicon technology would be favored. Semicrystaline silicon, galium arsenide, cadmium sulfide, and most concentrator approaches probably will not be ready for production scale-up until 1981-1983.

\subsubsection{Response Time for Proposal Submission}

The time available for a firm to respond to a major government procurement will have an impact on the type of firms that will be able to participate. Large firms with the capability and resources to prepare proposals using a significant number of their own staff have a relative advantage if proposal preparation time is short (one month to six weeks). These companies also usually have standing agreements with consultants or companies with strong capabilities in other aspects of the system. These arrangements make the team very competitive and do not require time to assemble af ter a request for proposals is received. Smaller firms (especially those producing only modules) would need two to three months or more to arrange supplies and prices of input materials over the contract life (especially polysilicon prices and availability), supplies of capital equipment, leases or other arrangements for additional floor space, bank financing for the expansion, consultant and other companies to bid as a team, and resources to write the proposal.

Relative to the issues of objectives, contract size, and evaluation criteria, the time allotment for preparing proposals is a minor issue. However, if this issue is ignored, it could seriously bias the best-designed procurement against small producers.

\subsubsection{Future Supplies and Prices of Polysilicon}

One of the key determinants of the future price of single crystal silicon solar cells will be the price and availability of the basic raw material, polysilicon. Currently, polysilicon supplies are creating a eignifioant problem for the industry. The current situation is characterized by a high demand for polysilicon by the semiconductor industry. Producers of polysilicon have two major options available in the short run. First, they can produce polysilicon and sell it to either the semiconductor industry or photovoltaic producers. Alternatively, they can use their polysilicon to pull single crystal silicon and then slice it into wafers. The wafers can be sold to the semiconductor or photovoltaic industry. This second option is most commonly followed because the added value of growing and slicing wafers exceeds the additional costs of production. Therefore, profit margins on the sale of wafers are significantly higher than those on the sale of raw polysilicon. The photovoltaic industry currently uses less than $1 \%$ of the polysilicon output. Photovoltaic producers are usually the last customers to be served by polysilicon suppliers. Therefore, availability of the material to photovoltaic companies, especially small photovoltaic companies, is currently a significant problem.

Higher demand for wafers and polysilicon is resulting in price increases. Currently, polysilicon prices range from $\$ 56-72 / \mathrm{kg}$. Future trends in the supply and demand for polysilicon are not particularly favorable to the photovoltaic industry. Most of the 
interviewed companies stated that polysilicon demanded by the semiconductor industry will remain high through the 1980 s. The expansionary plans of polysilicon producers are less than the projected expansion in demand for the material. Therefore, it is the prediction of the photovoltaic industry that polysilicon supplies and prices will remain a problem during the 1980s. The price of polysilicon produced using current production techniques is likely to escalate rather than decline over the next five to ten years. New polysilicon processes currently under development were not thought to be likely to enter commercial production before the mid-1980s.

\subsubsection{Dual-Pricing Problems}

If a fixed-price procurement strategy is pursued, many of the firms felt that prices for the government would be lower than private market prices. Some firms felt that government funding would be used to cover the amortization of the capital equipment. Commercial sales then would be used to recover variable costs and profits. The major dilemma of a dual-pricing situation is that it indicates a failure of the government to meet its stated price goals. On the other hand, some price differentials are warranted in the sale of photovoltaics because of the higher distribution and the handling costs of smaller orders. If these price differentials between government and commercial sales become significant, the issue of which represents the commercial price of photovoltaics is raised again.

\subsubsection{Market Impacts of Procurements}

The issues raised above deal almost exclusively with the effects of photovoltaic procurements on suppliers. The supplier response to alternative procurement strategies was the focus of this study. Equally important is the design of a procurement strategy that positively affects photovoltaic markets. Mechanisms for adequate purchaser involvement through cost sharing and other techniques need to be carefully considered before an effective procurement program is developed.

\section{2:12 Sales After Procurement Ends}

Most companies felt that international commercial photovoltaic markets would develop quickly in the 1981 time frame if system prices are reduced and module prices ranged from $\$ 2-4 / W_{p^{*}}$. Given this scenario, firms are comfortable that the production capacity available at the end of the government procurement (e.g., 1984) could be used to meet commercial demand if module prices equal approximately $\$ 2.50 / \mathrm{W}_{\mathrm{p}}$.

The concern over sustainable commercial markets at the conclusion of government procurements led some companies to warn that government sales should represent only $50 \%$ of any single company's total sales. If such a sales percentage is stipulated in a procurement, it would force the winning firms to seek commercial markets and prevent companies interested only in government sales from bidding on the procurements. 


\section{SECTION 6.0}

\section{CONCLUSIONS}

Two very different sources of information have been used in preparing this report: a literature review of government procurement policies and their effects on new technologies, and interviews with photovoltaic companies on the possible effects of alternative federal procurement programs. Conclusions resulting from both of these sources have been made individually in previous sections. This section combines these conclusions into a summary statement of the major results of the study.

\subsection{SIGNIFICANT DIFRERENCES EXIST BETWEEN EARLY SEMICONDUCTOR PRO- CUREMENTS AND PHOTOVOLTAIC PROCUREMENTS CURRENTLY BEING CONSIDERED}

Many analogies have been made concerning the role that the federal government could play in photovoltaic technology and the role that the government played in the development of semiconductor technology. Substantial evidence exists to conclude that procurements were an effective means of encouraging semiconductor technological advances and industrial development. Evidence also suggests that the influence of government procurements in the early stages of transistors and integrated circuits was greater than that of direct government research support, which in several instances produced disappointing results.

Early procurements of semiconductors differ from photovoltaic procurements currently being considered in the emphasis placed on technical achievements versus price reductions. One of the most important characteristics of the early DOD purchases of semiconductor products was that they emphasized performance, reliability, and design requirements. DOD was willing to purchase innovative products that could meet its needs at premium prices. Companies with a new product could be confident that the profitable early government market would allow them to recapture their research and development investments and to perhaps generate revenues for additional $R \& D$. Subsequent innovations and product improvements, which were responsible for making transistors and integrated circuits cheap enough to open large industrial and consumer markets, were made by companies through their own efforts.

Today, the technological advances needed from the photovoltaic industry are different from those first demanded of transistors, integrated circuits, or even photovoltaics in the first years of the industry. Photovoltaic cells have already been shown to function reliably and to meet technical performance requirements for many applications. The most important achievement required in photovoltaics is reduced cost. Introduction of lower cost as the primary requirement in photovoltaics is a complicating factor that greatly confuses the applicability of government procurements to photovoltaics. The situation is no longer as simple as the early days of the transistor or of photovoltaics, when the government was willing to pay a high price for a device that worked. 
It has been suggested that the government simply add low cost (perhaps expressed in terms of photovoltaic program price goals) to the list of performance and reliability requirements that the goverment demands in its procurements. When lower price becomes the objective of a government procurement of photovoltaics, the stimulus of the government market becomes indistinguishable from the stimulus of private markets. Companies are already confident that photovoltaic sales to private buyers can be increased dramatically if major reductions in cost can be achieved. Using government procurements to directly motivate lower photovoltaic costs may also eliminate an important benefit of government semiconductor procurements, which was the assurance of substantial, immediate rewards for initial technological advances.

Iypically, proposals for using federal procurements of photovoltaics as an incentive to reduce costs ignore the more subtle elements of previous successes in the semiconductor industry. The introduction of price reductions as the major objective of photovoltaic procurements is likely to change the influences that these procurements will have on industry development. This is not to say that procurements would not still positively influence the photovoltaic industry, but rather, the influence may be less than assumed.

\subsection{SMALL COST-BASED PROCUREMENTS ENCOURAGE INDUSTRY DIVERSITY AND PROVIDE PERFORMANCE INPORMATION}

The industry interviews found that small, widely dispersed, cost-based contracts for complete photovoltaic systems encourage diverse company participation and the application of a wide range of photovoltaic module technologies. This approach is also an effective means of providing information to both suppliers and potential users on photovoltaic applications. Because of their small size and short duration, these procurements will have few positive effects on industry investment and development plans except in very small companies. Module costs and prices are not likely to be reduced through this type of program, although the cost of complete photovoltaic systems may be indirectly reduced because of the experience with systems that is gained.

\subsection{IIXED-PRICE CONTRALIS COULD STIMULATE SHORT-TERM COST REDUC- TIONS BUT MAY CHANGE INDUSTRY STRUCTURE}

Large, multiyear, fixed-price contracts for photovoltaic modules that specify progressively lower module prices could reduce the market uncertainties faced by participating companies and stimulate investments leading to short-term module cost reductions. However, several serious problems with this approach were identified.

Fixed-price contracts that require progressively lower prices and closely follow the DOE module price goals place substantial pressure on photovoltaic module prices. Regardless of the size of individual contracts, most companies would be unwilling to bid on such a contract. Although many companies are confident that substantial reductions in photovoltaic costs will be achieved, they are not willing to have future deliveries sold at some as yet unattained prices. This attitude is consistent with the procurement literature 
review which found that fixed-price contracts are typically used for well-defined products and production processes with long histories of commercial production. To expect companies to enter fixed-price contracts before a given price level has been achieved is unrealistic.

Large photovoltaic module procurements at fixed prices corresponding to DOE price goals could significantly reduce the number of companies actively producing photovoltaic modules. Companies with access to substantial financial resources would be most capable of responding to this type of procurement because of the risk of losses associated with not making cost reductions on the schedule needed to sell modules at predetermined prices. Small businesses in particular could have difficulty competing in this environment. With a few companies producing large quantities of modules under government contracts, it is likely that these companies would also enjoy a significant advantage in private markets.

The interviews with photovoltaic companies suggest that module prices are extremely competitive today (i.e., profit from module sales is minimal because prices and costs are nearly equal). Adding more pressure on prices through a fixed-price procurement program that specifies lower prices may put the government in an awkward position of encouraging price competition that is not based on costs. It is possible that companies receiving multiyear fixed-price contracts could be forced to sell modules or systems to the government at prices below costs if they are unable to meet anticipated cost reduction schedules or terminate their contracts. The government would then have given large contracts to companies that did not make as much progress in reducing costs as initially hoped. At the same time, these large contracts to a few companies might have discouraged the activities and harmed the commercial position of other firms that were unwilling to make bold promises, but that were equally capable of reducing costs.

A fixed-price procurement of modules ignores the broader problem of photovoltaic costs, which is to reduce the cost of complete photovoltaic systems. To focus on module prices may not help reduce total system costs. Fixed-price system procurements would be difficult to implement but do give proper attention to installed system costs.

\subsection{PRODUCTION FACIITY SUBSIDIES AND INNOVATIVE PRODUCT PROCURE- MENTS ARE ATTRACTIVE TO SOME COMPANIES}

Several companies interviewed found a production facility subsidy strategy attractive. The strength of this approach is that it provides direct support of improved production techniques and facilities. Other companies believe that those firms with real production advances should be able to obtain private venture capital to support their plant improvements. Information disclosure requirements could be a serious deterrent to many companies participating in a program involving production facility subsidies.

A procurement program that offers multiyear contracts for the purchase of modules using innovative production techniques was thought by many companies to be a worthwhile complement to any federal procurement program. Problems in implementing this 
strategy, especially the problem of evaluating the potential for cost reduction, made some companies conclude that this strategy could not be effectively implemented.

\subsection{PROCUREMENT STRATEGIES SHOULD BE MATCHED WITH OBJECTIVES}

Before an effective photovoltaic procurement program can be designed, it will be necessary to clearly state the objectives of the program. Several possible objectives of photovoltaic procurement have been identified. Procurements could be pursued to provide information to both supplier and potential users on photovoltaic applications, to stimulate photovoltaic system cost reductions or to expand industry capacity. Stimulating diverse industry participation is another possible objective.

Informational objectives could be served through system procurements of relatively small magnitude similar to the DOE system test and applications projects currently being funded. Multiyear system contracts of larger size are more likely to stimulate cost reductions by encouraging companies to implement improved production techniques and system designs. The expansion of capacity could be induced by large procurements over a relatively long period. Awarding government procurements to many companies would encourage industry diversity and competition.

The literature review suggests that future procurements intended to advance private sector photovoltaic applications and industry development should concentrate on achieving informational objectives. Federal support of research, development, and demonstration for technologies to be used by the private sector has primarily been oriented toward providing information on these new technologies, their production, and possible applications. Little precedent exists for large-scale federal procurements in excess of federal needs that are intended to advance the development of an industrial base for a technology to be used by the private sector.

Once the objectives of a procurement program have been defined, several details of procurement strategy design should be carefully considered. The length of a procurement contract, the evaluation criteria used in making awards, the size of contracts, and the time allowed for proposal response are among the details that are critical to the design and implementation of an effective procurement program. These details have to be resolved before a procurement strategy is implemented.

\subsection{EFFECTS OF PHOTOVOLTAIC PROCUREMENTS ON POTENTIAL PURCHASERS NEED TO BE EXAMINED}

This study has been confined to consideration of the effects of government procurements on the photovoltaic supply industry. The review of historical federal procurements found that successful commercial products have resulted from programs that have made convincing demonstrations of the usefulness of the product to potential users. The responses of potential users are as important to the development of a federal photovoltaic procurement strategy as the supply side effects. User cost sharing, as well as other mechanisms for ensuring adequate involvement of private users, should be examined to 
magnify the effects of the program on the private market. Involvement of users is also consistent with the guidelines governing federal assistance programs that are outlined in the Federal Grant and Cooperative Agreement Act of 1977. It is likely that any newly initiated federal procurement program motivated to advance the photovoltaic industry and markets (and not limited to the purchase of photovoltaics for use in federal facilities) will be required to comply with guidelines governing federal assistance programs.

\subsection{CLEAR STATEMENT OF ANTICIPATED FEDERAL PHOTOVOLTAIC PROGRAM PROCUREMENTS WOULD MAGNIFY IMPACTS}

One of the messages coming from the industry interviews was that until the federal government outlines a viable, consistent, and predictable program to purchase photovoltaic systems, it will be difficult for the government to positively influence industrial investment or cost reduction plans. A program that changes from year to year or that does not proceed as originally planned only adds to market uncertainty and has a negative effect on industry planning. These changes also reduce the credibility of future programs and dampen industry response. 


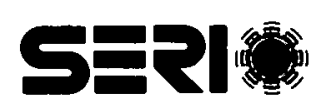




\section{SECTION 7.0}

\section{REPBRENCES}

1. DOE Information Memorandum to the Under Secretary from the Acting Program Direc tor for Solar, Geothermal, Electric, and Storage Systems; December 21, 1977.

2. Costello, Dennis; Posner, David; Schiffel, Demnis; Doane, James; Bishop, Charles. Photovoltaic Venture Analysis. Golden, CO: Solar Energy Research Institute; July 1978.

3. DOE Information Memorandum from the Under Secretary to the Assistant Secretary for Energy Technology; June 7, 1978.

4. U.S. Department of Energy. Solar Energy Program Summary Document: FY81. Washing ton, D.C.: January. 1980.

5. Department of Energy Act of 1978: Civilian Applications. P.L. 95-238, Section 208.

6. National Energy Conservation Policy Act of 1978. P.L. 95-619, Title V, Part 4, Section 56 1-569; November 9, 1978.

7. Solar Photovoltaic Energy Research, Development, and Demonstration Act of 1978. P.L. 95-590.

8. Jet Propulsion Laboratory. "Fixed Price Buy Option Feasibility Study." Unipublished paper; Pasadena, CA: JPL; $1978^{\circ}$

9. "\$2/Watt Buy Concept." DOE Memorandum from A.S. Clarfeine, Office of Planning and Technology Transfer, to Bennett Miller, Acting Program Director for Solar, Geothermal, Electric, and Storage Systems. June 27, 1978.

10. U.S. Government Accounting Office. Financial Status of Major Acquisitions. January 1977. As cited in a repart to Congress by the Comptroller General of the United States; An Organized Approach to Improving Federal Procurement and Acquisition Practices. Washington, D.C.: September 30, 1978.

11. Report of the Commission on Government Procurement, Volumes 1-4 and Summary. Washing ton, D.C.; U.S. Government Printing Office; December 1972.

12. Peck, Merton J.; Scherer, Frederick M. The Weapons Acquisition Process: An Economic Analysis. Cambridge, MA: Harvard Business School; 1962.

13. Office of Technology Assessment. Applications of R\&D in the Civilian Sector: The Opportunity Provided by the Federal Grant and Cooperative Agreement Act of 1977. Washington, D.C. U.S. Government Printing Office; p. 9. 
14. McEachron, Norman; et al. Management of Federal R\&D for Commercialization. Menlo Park, CA: SRI International, September 1978; pp. II-4-II-9.

15. Office of Federal Procurement Policy Act of 1974; P.L. 93-400; 1974.

16. Office of Federal Procurement Policy. Report to the Congress: January 1977 thru September 1978. Washington, D.C.:. Office of Management and Budget; January 2, 1979.

17. Advisory Subcommittee on Procurement and Direct Support of Research Development, Advisory Committee on Industirial Innuvation to Domestlc Pollcy Review. Federal Procurement Policy, Draft Report. Washington, D.C.: U.S. Department of Commerce; December 22, 1978.

18. Tíbbetts, Roland. Small Business Innovation Applied to National Need. Washington, D.C.: National Science Foundation; February 1978. .

19. Moore, Frederick T. 'Military Procurement and Contracting: An Economic Analysis. Santa Monica, CA: Rand Corporation; June 1962.

20. Perry, Robert; Smith, Giles K.; Harman, Alvin J.; Henrichsen, Susan. System Acquisition Strategies. Santa Monica, CA: Rand Corporation; June 1971.

21. Johnson, Leland; Merrow, Edward; Paer, Walter; Alexander, Arthur. Appendix B: "Experience of the Department of Defense with Incentive Contracting." Alternative Institutional Arrangements for Developing and Commercializing Breeder Reactor Technology. Santa Monica, CA: Rand Corporation; November 1926.

22. Utterback, James M.; Murray; Albert E. The Influence of Defense Procurement and Sponsorship of Research and Development on the Development of the Civilian Electronic Industry. Cambridge, MA: MIT Center of Policy Alternatives; June 20, 1977.

23. Tilton, John E. International Diffusion of Technology: The Case of Semiconductors. Washington, D.C.: The Brookings Institution; 1971.

24. Asher, Norman J.; Strom, Leland D. The Role of the Department of Defense in the Development of Integrated Circuits. Arlington, VA: Institute for Defense Analyses; May 1977.

25. Golding, Anthony M. The Semiconductor Industry in Britain and the United States: A Case Study of Innovation, Growth, and Diffusion of Technology. Unpublished Ph.D. dissertation; University of Sussex; 1971. Reprinted in part in Asher, Norman J.; Strom, Leland D. The Role of the Department of Defense in the Development of Integrated Circuits. Arlington, VA: Institute of Defense Analyses; May 1977. 
26. Braun, Ernest; MacDonald, Stuart. Revolution in Miniature: The History and Impact of Semiconductor Electronics. Cambridge, MA: Cambridge University Press; 1978.

27. Kleiman, Herbert S. The Integrated Circuit: A Case Study of Product Innvation in the Electronics Industry. Unpublished Ph.D. dissertation; George Washington University; 1966. Reprinted in part in Asher, Norman J.; Strom, Leland D. The Role of the Department of Defense in the Development of Integrated Circuits. Arlington, VA: Institute for Defense Analyses; May 1977.

28. Schnee, Jerome E. "Government Programs and the Growth of High Technology Industries." Research Policy. (No. 7): 1978; pp. 2-24. 


\section{SEPls}




\section{APPENDIX A}

\section{PROPLE OF PHOTOVOLTAIC INDUSTRY TODAY*}

To develop a profile of today's photovoltaic industry, the industry must be examined from several different points of view. This appendix first discusses the historical volume of photovoltaic modules sold by the industry, the markets in which these sales have been made to date, and the historical price trends of photovoltaic modules. Second, the characteristics of module manufacturing companies are described. Third, current marketing and distribution mechanisms for photovoltaic systems are depicted. Finally, characteristics of companies that are today only performers of $R \& D$ are described.

\section{A.1 HISTORICAL TRENDS IN MODULE SALES AND PRICES}

The technological capability to produce a photovoltaic cell for commercial use was first demonstrated in 1953. During the 1950s, modules were sold for a variety of highly specialized applications, with the majority of sales made for space applications. Space program sales continued to be the primary photovoltaic application throughout the 1960 s. In the early 1970 s, photovoltaics began to be used more extensively terrestrially.

Between 1973 and 1975, sales of terrestrial photovoltaic cells were on a small scale, with the cumulative industry production of terrestrial modules totaling well under one peak megawatt ( $M W_{\mathrm{p}}$ ) of capacity.** In 1976, the first detailed studies of the sales of photovoltaic modules were made. The results of these studies are shown in Table A-1. Both the survey by the BDM Corporation [A1] and InterTechnology Solar Corporation [A2] estimated shipments of photovoltaic modules by U.S. manufacturers during 1976 at approximately 400 peak kilowatts. The exact sources of sales are described differently by these two studies. Nevertheless, several trends are evident. In 1976, sales for terrestrial applications exceeded space applications by almost a factor of ten. However, federal government purchases comprised almost one-third of the total market. After 1976, only aggregate estimates of module sales are available. Two sources estimate that 1977 sales were approximately $750 \mathrm{~kW}_{\mathrm{p}}$, with shipments estimated by one of the sources at about $500 \mathrm{~kW}_{\mathrm{p}}$ [A3, A4]. Terrestrial module sales in 1977 have been estimated in a recent industry assessment by Booz-Allen to generate approximately $\$ 15$ million in revenués to producing companies [A4, p. IV-26]. Sales for 1978 have been estimated by Booz-Allen to be over $1 \mathrm{MW}_{\mathrm{p}}$, with shipments on the order of $700-800 \mathrm{~kW}_{\mathrm{p}}$ [A4, p. III-2].

*Changes in the industry are rapid, and the information in this appendix is current as of the period of the study (early 1979).

**A peak watt measures the output of the devices at their maximum operating capacity under full sun. . 
Table A-1. 1976 PHOTOVOLTAIC MODULE SALES

(Kilowatts Peak)

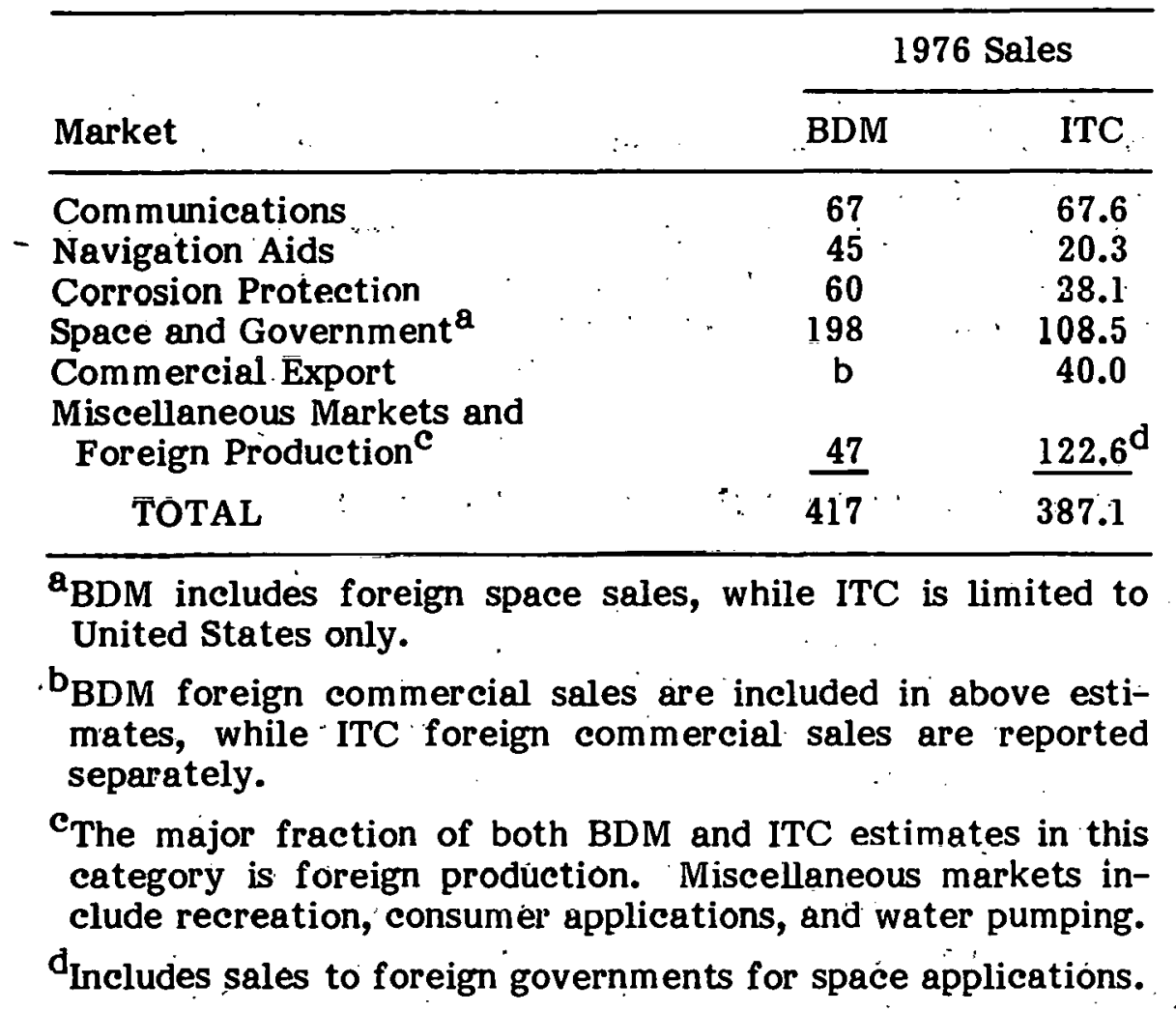

Table A-1 shows that the major commercial markets for photovoltaic modules are in communications and cathodic protection. In both these markets, sales are being made for systems operating in remote locations with small (usually less than $1 \mathrm{~kW}_{\mathrm{p}}$ ) power requirements. Photovoltaics effectively compete with utility-generated power in these markets because of the high cost of utility line installation and very small energy consumption. Batteries, thermal electric generators, and diesel generators are also common - power sources for which photovoltaic systems are substituted. Both batteries and smallscale generators have high maintenance costs, and generators typically have poor reliability characteristics, making them expensive to use in a remote setting. A small quantity of sales have been made in consumer and recreation markets (battery chargers for recreational vehicles, watches, etc.) and for remote water-pumping systems located in foreign countries. It is also worthwhile to note from Table A-1 that a sizable percentage of the 1976 sales were made in foreign markets. Current opinion indicates that a major portion of future photovoltaic sales will be made in foreign markets, particularly as further decreases in the price of photovoltaic modules are achieved.

\section{A.2 PHOTOVOLTAIC PRICE TRENDS}

Substantial reductions in the price of photovoltaic modules have been realized since the first arrays designed for terrestrial use were manufactured in the early 1970s. The first 
large federal purchases of modules for terrestrial use in 1975 were at an average price of approximately $\$ 20 / W_{p}[A 5$, p. 10]. This was a significant reduction in cost from the $\$ 200 / \mathrm{W}_{\mathrm{p}}$. paid for modules used in space applications. The results of a 1978 SERI survey of commercial module prices are shown in Table A-2. In small quantities, modules sell for $\$ 15-\$ 36 / W_{p}$, depending on the supplier and the exact quantity purchased. In large quantity purchases, module prices range from $\$ 10-\$ 15 / \mathrm{W}_{\mathrm{p}}$.

Table A-2. RESULTS OF SERI TELEPHONE SURVEY ON PRICES OF PHOTOVOLTAIC MODULES JUNE $1,1978^{\mathrm{a}}$

\begin{tabular}{|c|c|c|c|c|}
\hline Company $^{b}$ & $\begin{array}{l}\text { Module Size } \\
\left(w_{p}\right)\end{array}$ & $\begin{array}{l}\text { Price Quotes } \\
\left(\$ / W_{p}\right)\end{array}$ & Quantity & Comments - \\
\hline $\mathbf{A}$ & 24.00 & $\begin{array}{c}27.90 \\
24.70 \\
22.45 \\
- \\
14.00\end{array}$ & $\begin{array}{r}1-9 \text { modules } \\
10-24 \text { modules } \\
25-99 \text { modules } \\
\text { 100-999 modules } \\
1000 \text { modules }\end{array}$ & $\begin{array}{l}\text { End-user prices are pro- } \\
\text { vided here. Distribu- } \\
\text { tor prices are about } \\
20 \% \text { less. }\end{array}$ \\
\hline$\cdots$ & $\begin{array}{r}9.60 \\
25.00 \\
33.00\end{array}$ & $\begin{array}{c}17.00-\text { over } 20.00 \\
- \\
10.00-15.00\end{array}$ & $\begin{array}{l}\text { Price dependent } \\
\text { upon quantity. }\end{array}$ & $\begin{array}{l}\text { These are OEM (i.e., } \\
\text { wholesale to Original } \\
\text { Equipment Manufactur- } \\
\text { ers) prices. The end } \\
\text { user will generally } \\
\text { pay between 10-25\% } \\
\text { more. Large purchases } \\
\text { by end user will } \\
\text { approach the OEM } \\
\text { prices. }\end{array}$ \\
\hline $\mathrm{C}$ & 20.00 & $\begin{array}{l}15.00 \\
14.00 \\
13.00 \\
12.00 \\
11.00 \\
10.00\end{array}$ & $\begin{array}{r}100 \mathrm{~W}_{\mathrm{p}} \text { order } \\
500 \mathrm{~W}_{\mathrm{p}} \text { order } \\
1.5-2 \mathrm{~kW} \text { order } \\
5 \mathrm{~kW} \text { order } \\
7 \mathrm{~kW}_{\mathrm{p}} \text { order } \\
10 \mathrm{~kW}_{\mathrm{p}} \text { order }\end{array}$ & $\begin{array}{l}\text { These are end-user } \\
\text { prices. A discount of } \\
15-20 \% \text { is given to } \\
\text { distributors. }\end{array}$ \\
\hline $\mathrm{D}$ & 10.56 & $\begin{array}{l}36.00 \\
32.40 \\
28.80 \\
26.10 \\
23.80 \\
30.00 \\
27.00 \\
24.00 \\
21.00 \\
20.00\end{array}$ & $\begin{array}{r}1-9 \text { modules } \\
10-49 \text { modules } \\
50-99 \text { modules } \\
100-249 \text { modules } \\
250-499 \text { modules } \\
1-9 \text { modules } \\
10-49 \text { modules } \\
50-99 \text { modules } \\
100-249 \text { modules } \\
250-499 \text { modules }\end{array}$ & $\begin{array}{l}\text { End-user prices. Other } \\
\text { sized modules are } \\
\text { manufactured but these } \\
\text { are the two best sellers. }\end{array}$ \\
\hline
\end{tabular}


Table A-2. RESULTS OF SERI TELEPHONE SURVEY ON PRICES OF PHOTOVOLTAIC MODULES-JUNE $1,1^{2} 8^{\mathrm{a}}$ (continued)

\begin{tabular}{|c|c|c|c|c|}
\hline Company $^{b}$ & $\begin{array}{l}\text { Module Size } \\
\left(w_{p}\right)\end{array}$ & $\begin{array}{l}\text { Price Quotes } \\
\qquad\left(\$ / w_{p}\right)\end{array}$ & Quantity & Comments \\
\hline E & $\begin{array}{l}20.00 \\
12.00\end{array}$ & $\begin{array}{l}31.20 \\
15.60 \\
32.00 \\
16.00\end{array}$ & $\begin{array}{c}\text { Small } \\
50 \text { modules } \\
\text { Small } \\
100 \text { modules }\end{array}$ & $\begin{array}{l}\text { End-user prices. The } \\
\text { company manufactures } \\
\text { a variety of panels. } \\
\text { These two examples } \\
\text { show the price struc- } \\
\text { ture: } 20 \mathrm{w}_{\mathrm{p}}, 50 \% \text { dis- } \\
\text { count on orders of mod- } \\
\text { ules or more ( } 52 \% \text { for } \\
\text { GSA orders); panels } \\
\text { smaller than } 20 \mathrm{~W}_{\mathrm{p}}, 50 \% \\
\text { discount on orders of } \\
100 \text { modules or more } \\
\text { ( } 52 \% \text { for GSA orders). } \\
\text { Distributor prices are } \\
50 \% \text { off listed prices. }\end{array}$ \\
\hline
\end{tabular}

${ }^{a}[A 6$, p. 4].

${ }^{b}$ Company names were withheld to ensure their cooperation.

The cost of a complete photovoltaic system is somewhat higher than the modules alone. The exact cost of the system depends on design considerations; 1.e., type of modules, power conditioning devices, batteries, supporting structure, and installation. For systems being installed today, costs range from $\$ 20-40 / W_{p}$ [A7].

\section{A.3 COMPANIES MANUFACTURING TODAY}

Table A-3 lists the companies that are currently manufacturing terrestrial photovoltaic modules. Eight companies are producers of photovoltaic modules. All eight companies produce single-crystal silicon, flat-plate modules. Production prototypes for concentrating modules using single-crystal silicon have been completed by several manufacturers. However, no company is producing concentrators for sale to the open market, although such activities are imminent.*

Other candidate photovoltaic module technologies are in various stages of research and development. Plans for production of polycrystalline silicon, thin-film cadmium sulfide, and single-crystal and special-concentrating gallium arsenide modules are now being

*Several companies have constructed concentrating modules with their own funds and with the support of the federal research and development program. 
formulated. Other technologies such as thin-film silicon, gallium arsenide and indium phosphorous, polycrystalline gallium arsenide, and advanced concentrator materials will require substantial research progress before commercial production can be anticipated.

\section{Table A-3. CHARACTERISTICS OF COMPANIES CURRENTLY PRODUCING PHOTOVOLTAIC MODULES ${ }^{\mathrm{a}}$}

\begin{tabular}{|c|c|c|c|c|}
\hline \multirow[b]{2}{*}{$\begin{array}{l}\text { Photovoltaic } \\
\text { Company }\end{array}$} & \multirow[b]{2}{*}{$\begin{array}{l}\text { Parent Company } \\
\text { (Major Business } \\
\text { Classification) }\end{array}$} & \multicolumn{3}{|c|}{ Module Technology } \\
\hline & & $\begin{array}{l}\text { Single } \\
\text { Crystal } \\
\text { Silicon }\end{array}$ & $\begin{array}{l}\text { Flat } \\
\text { Plate }\end{array}$ & $\begin{array}{l}\text { Concen- } \\
\text { trator }\end{array}$ \\
\hline ARCO Solar, Inc. & $\begin{array}{l}\text { Atlantic Richfield Co. } \\
\text { (Energy) }\end{array}$ & $\mathrm{X}$ & $\mathrm{X}$ & - \\
\hline Motorola & Motorola (Electronics) & $\mathrm{X}$ & $\mathrm{X}$ & -- \\
\hline OCLI & OCLI (Electronics) & $\mathrm{X}$ & $\mathrm{X}$ & - \\
\hline Sensor Technology Corp. & ASPRO & $\mathrm{X}$ & $\mathrm{X}$ & - \\
\hline Solarex & (Photovoltaics) & $\mathrm{X}$ & $\mathrm{X}$ & - \\
\hline Solar Power Corp. & Exxon (Energy) & $\mathrm{X}$ & $\mathrm{X}$ & - \\
\hline SOLEC International & (Photovoltaics) & $\mathrm{X}$ & $\mathrm{X}$ & - \\
\hline Solenergy & (Photovoltaics) & $\mathrm{X}$ & $\mathrm{X}$ & - \\
\hline
\end{tabular}

$\mathrm{a}[\mathrm{A} 4, \mathrm{p} . \mathrm{I}-2 ; \mathrm{A} 8]$.

The earliest manufacturers of terrestrial modules produced photovoltaic cells for space applications. OCLI (formerly Centralab) and Sensor Technology are two current producers that fall into this category. International Rectifier and Spectrolab are also space cell producers that were early manufacturers of terrestrial modules. Both International Rectifier and Spectrolab have now ceased terrestrial module production [A4, p. IV-3].

Other current module producers include two oil company subsidiaries, ARCO Solar, Inc. (Atlantic Richfield Company), and Solar Power Corporation (Exxon). Motorola, a major electronics and semiconductor company, has diversified into photovoltaic module production. Finally, three independent new companies, Solarex, Solenergy, and Solec International, manufacture photovoltaic modules.

Table A-4 shows the current production capacity and estimated production rates for seven producing companies. While the industry has an estimated module production capacity of $2,900 \mathrm{~kW}_{\mathrm{p}}$, only $800 \mathrm{~kW}_{\mathrm{p}}$ is expected to be produced in 1978, representing an industry capacity utilization of $27.5 \%$. Five companies are the major current producers, with production spread almost evenly between these five companies. Industry revenues in 1977 from terrestrial module production have been estimated by Booz-Allen at approximately $\$ 15$ million.

All of the companies currently producing photovoltaic modules are also currently performing some research and development. Major $R \& D$ emphasis is on production process 
development, although OCLI, Sensor Technology, ARCO Solar, Solar Power, and Solarex also have some $R \& D$ programs in photovoltaic materials $R \& D$.

Table A-4. ESTIMATED INVESTMENT AND PRODUCTION RATES OF FIRMS PRODUCING AND MARKETING SINGLE-CRYSTAI. SIIICON PHOTOVOLTAICS IN $1978^{8}$

\begin{tabular}{|c|c|c|c|}
\hline Company & $\begin{array}{c}\text { Estimated Annual } \\
\text { Production Capacity } \\
\left(\mathrm{kW} \mathrm{w}_{\mathrm{p}} / \mathrm{yr}\right)\end{array}$ & $\begin{array}{l}\text { Current Annual } \\
\text { Production Rate } \\
\left(\mathrm{kW}_{\mathrm{p}} / \mathrm{yr}\right)\end{array}$ & $\begin{array}{c}\text { Capacity } \\
\text { Utilization } \\
\text { (\%) }\end{array}$ \\
\hline $\begin{array}{l}\text { A } \\
\text { B } \\
\text { C } \\
\text { D } \\
\text { E } \\
\text { F } \\
\text { G }\end{array}$ & $\begin{array}{r}700 \mathrm{~kW}_{\mathrm{p}} \\
300 \mathrm{~kW} \\
1,000 \mathrm{~kW} \\
500 \mathrm{~kW} \\
300 \mathrm{~kW} \\
100 \mathrm{~kW} \\
\text { Negl. }\end{array}$ & $\begin{array}{c}200 \mathrm{~kW}_{\mathrm{p}} \\
\mathrm{Negl}^{\mathrm{p}} \\
150 \mathrm{~kW} \\
175 \mathrm{~kW}_{\mathrm{p}}^{\mathrm{p}} \\
175 \mathrm{~kW}_{\mathrm{p}}^{\mathrm{p}} \\
100 \mathrm{~kW} \\
\text { Negl. }\end{array}$ & $\begin{array}{c}25 \\
0 \\
15 \\
35 \\
58 \\
100 \\
\text { N/A }\end{array}$ \\
\hline Totals & $2,900 \mathrm{~kW}_{\mathrm{p}}$ & $800 \mathrm{~kW}_{\mathrm{p}}$ & $27.5 \%$ \\
\hline
\end{tabular}

${ }_{[A 4, p .}$ IV-31].

According to the Booz-Allen industry assessment, these companies have similar nearterm problems despite the diverse sizes and corporate backgrounds of current module producers [A4, p. IV-9, IV-24]. First, each company is attempting to develop a viable business by adapting existing technology to new markets. Second, these companies are primarily interested in making immediate sales and advances in production efficiency. Third, the three subsidiaries of major corporations and two divisions of larger corporations, although affiliated with established business operations with substantial financial resources, are in actuality new ventures that are similar to a small new business and face similar problems to the three independent new companies.

An industry assessment by Gnostic Concepts, Inc. points out a basic difference between the small independent venture and the subsidiary or division of a large corporation [A9, p. 103]. Small independent ventures are typically underfinanced and do not have financial resources adequate to sustain development costs and maintain a viable business. Large corporations have large amounts of capital with which a new photovoltaic company can be financed and that can sustain early losses for longer-term opportunities. Given these qualities, it is not surprising that many large, corporate photovoltaic activities were started by acquisition of small independent ventures as summarized in Table A-5, or by formation of joint ventures such as the Mobil Tyco Solar Energy Corporation (a joint venture between Mobil and Tyco Laboratories). 
Table A-5. ACQUISITION OF PHOTOVOLTAIC COMPANIES ${ }^{a}$

\begin{tabular}{|c|c|c|}
\hline Present Company & Acquisition & Acquirer \\
\hline ARCO Solar, Ine & $\begin{array}{l}\text { Solar Technology } \\
\text { International }\end{array}$ & $\begin{array}{l}\text { Atlantic Richfield } \\
\text { Company }\end{array}$ \\
\hline Photon Power & D. H. Baldwin - & $\begin{array}{l}\text { Compagnie Francaise } \\
\text { des Petroles (55\%) } \\
\text { and Libbey Owens } \\
\text { Ford }(43 \%)\end{array}$ \\
\hline Solar Power Corporation & Solar Power Corporation & Exxon Corporation \\
\hline SES & SES & $\begin{array}{l}\text { Shell Development } \\
\text { Corporation }\end{array}$ \\
\hline Sensor Technology, Inc. & Sensor Technology, Inc. & ASPRO, Inc. \\
\hline OCLI & Centralab & OCLI \\
\hline Spectrolab & Spectrolab & Hughes Aircraft \\
\hline
\end{tabular}

${ }^{a}[A 9$, p. 103].

\section{A.4 MARKETING AND DISTRIBUTION}

Producing companies have as yet invested a limited amount of funds in marketing photovoltaic products. In 1977, Booz-Allen estimates industrywide marketing expenditures at less than $\$ 2$ million [A4, p. IV-26]. This estimate includes the cost of marketing studies, advertising, sales offices, sales materials, as well as other marketing expenses. A DOE task force report found that less than 30 persons are currently employed as sales and product engineers by the industry [A10, p. 3]. Photovoltaic sales to date have occurred mostly on an ad-hoc basis, resulting from unsolicited inquiries as opposed to industry marketing activities. More recently, several photovoltaic companies have increased their marketing efforts through their affiliated companies and original equipment manufacturers of pumps and other equipment that can be powered by photovoltaics.

While many sales are made without the involvement of an intermediate company, some systems are engineered by special equipment systems houses, which then sell the entire system to the ultimate purchaser. Cathodic protection companies; for example, design individualized photovoltaic corrosion protection systems for interested customers. Modules are purchased by the corrosion protection companies and then resold to the purchaser as an entire system. A 30\% markup is applied to the module itself and a $100 \%$ overhead charge applies to the other system components. A group of corrosion protection companies believed this pricing policy to represent the minimum markup that would allow a normal profit in the sale of photovoltaic systems [A6, p. F-30].

Uncertainty in the size of near-term and intermediate markets and the price at which photovoltaics can compete in those markets is one of the major problems currently confronting companies producing photovoltaic modules. Most market studies suggest 
that near-term and intermediate markets will be highly fragmented, with major intermediate markets located outside the United States. This fragmentation and speculation of a promising foreign market will pose significant marketing problems for the industry. Servicing a wide variety of customers, many of whom require special products, is of ten a costly enterprise. Foreign marketing costs are typically very high. Given the poor understanding of photovoltaic markets, their fragmented nature; and possible foreign competition, module manufacturers face serious difficulties selling large quantities of photovoltaic modules in the future.

\section{A.5 RESEARCH AND DEVELOPMENT PERFORMERS}

As mentioned previously, current producers of photovoltaic modules also perform research and development. In addition, there are several companies that currently do not produce modules but are conducting research and development related to photovoltaics. Table A-6 lists these companies and shows the general nature of their $R \& D$ activities. The table also indicates the major business activity of the company.

Production process development includes refinements and development of single-crystal silicon, polycrystalline silicon, thin-film cadmium sulfide, and gallium arsenide production technologies. Development of production techniques for concentrating modules also are included under production process development. Photovoltaic materials research and development encompasses silicon, gallium arsenide, indium phosphorous, and other thinfilm technologies as well as polycrystaline silicon, gallium arsenide, and advanced concentrator cells.

In addition to the seven producing companies, approximately ten other companies are performing production process development. As Table A-6 shows, these companies include three additional energy companies performing $R \& D$ through acquired subsidiaries, three semiconductor and electronics companies, and four hardware research companies conducting internal $R \& D$. These ten companies, plus three major semiconductor and electronics firms, two additional hardware research companies, and an energy company, are also conducting $R \& D$ on photovoltaic materials. Two solar energy companies are also conducting production process development on photovoltaic concentrators. The bulk of the raw materials $R \& D$ is currently being performed by six established materials suppliers. General Electric is also performing some materials $R \& D$, as is Motorola.

Almost every company currently conducting photovoltaic R\&D is working with government funds. Only a few companies are working exclusively with private funds. Many companies that are participants in the government program are also funding some photovoltaic research internally. Booz-Allen found that, of the approximately $\$ 53 \mathrm{mil}-$ lion spent by companies on photovoltaic $R \& D$, nearly $\$ 45$ million is supported by the federal government.

Booz-Allen interviews with thirteen companies currently performing photovoltaic R\&D revealed that these companies have different $R \& D$ objectives and commitments to photovoltaics. Three different groups of companies were found [A4, pp. IV-20, IV-24]. One group consists of two companies that have "an aggressive development orientation 
and may bring their technologies to market in the near term." One of these companies is pursuing cadmium sulfide and the other single-crystal and polycrystalline silicon. A second group contains five companies that are pursuing longer-term $R \& D$ oriented toward establishing a competitive advantage in long-term markets. These companies are typically working on well-focused projects and are financing their work with both internal and federal funds. The third group consists of six companies that are conducting R\&D exclusively under federal support. Corporate commitments to photovoltaics by this third group are low and contingent on continued federal support.

Table A-6. R\&D ACTIVITIES OF COMPANIES EXCLUSIVELY PERFORMING R\&D ${ }^{\mathrm{a}}$

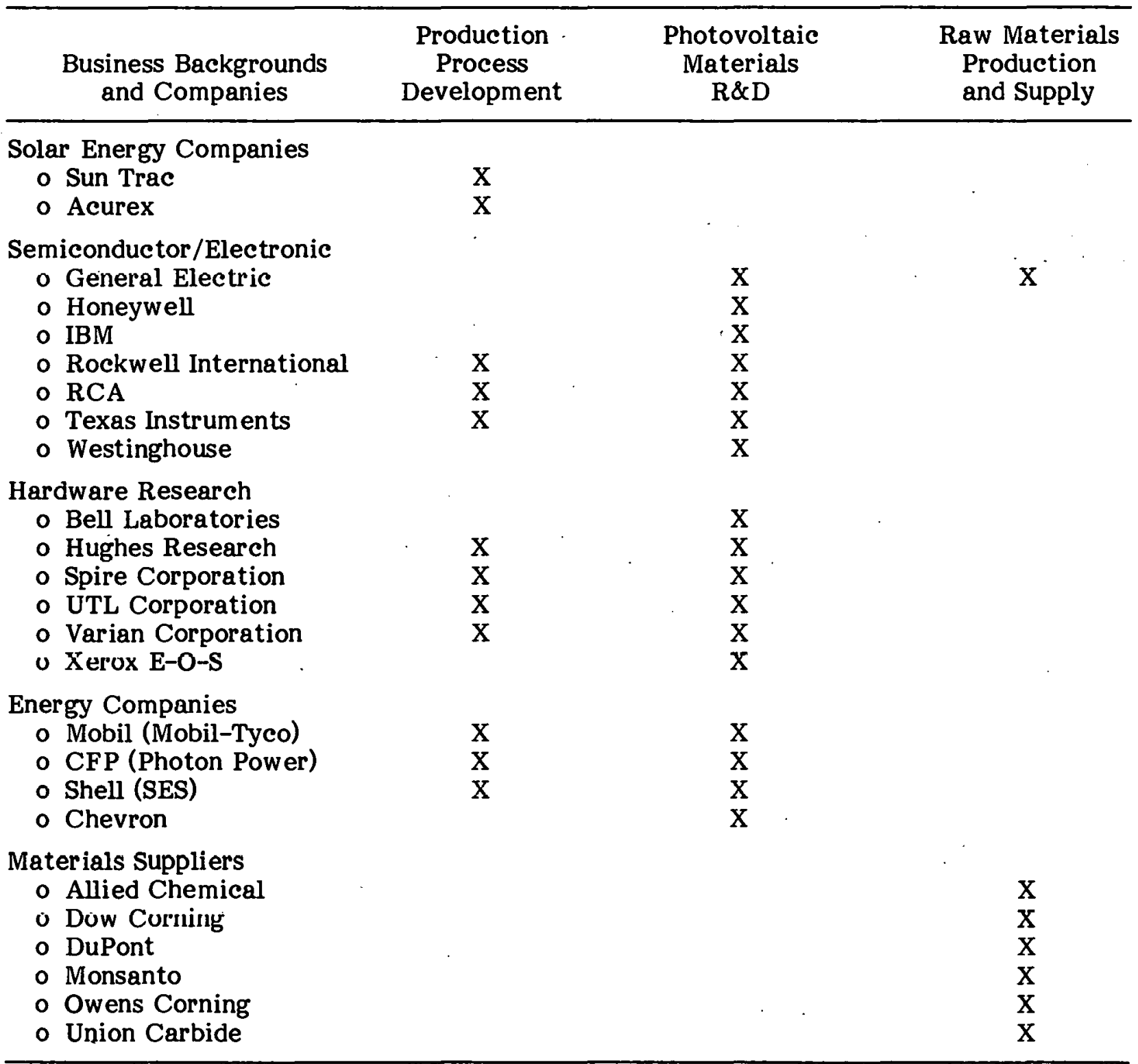

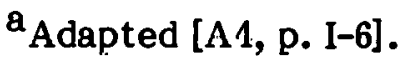




\section{A.6 SUMMARY}

The photovoltaic industry today is primarily an R\&D industry financed by the federal government. As illustrated in Figure $A-1$, the major source of revenues is federal $R \& D$ expenditures, while the major use of funds is for R\&D. Investment in production equipment and marketing activities represent less than $15 \%$ of the funds used by the industry. However, assuming that these activities are paid for with private funds, production and marketing accounts for more than $50 \%$ of the private investment by industry. A few companies are pursuing $R \& D$ programs exclusively or primarily with their own funds.

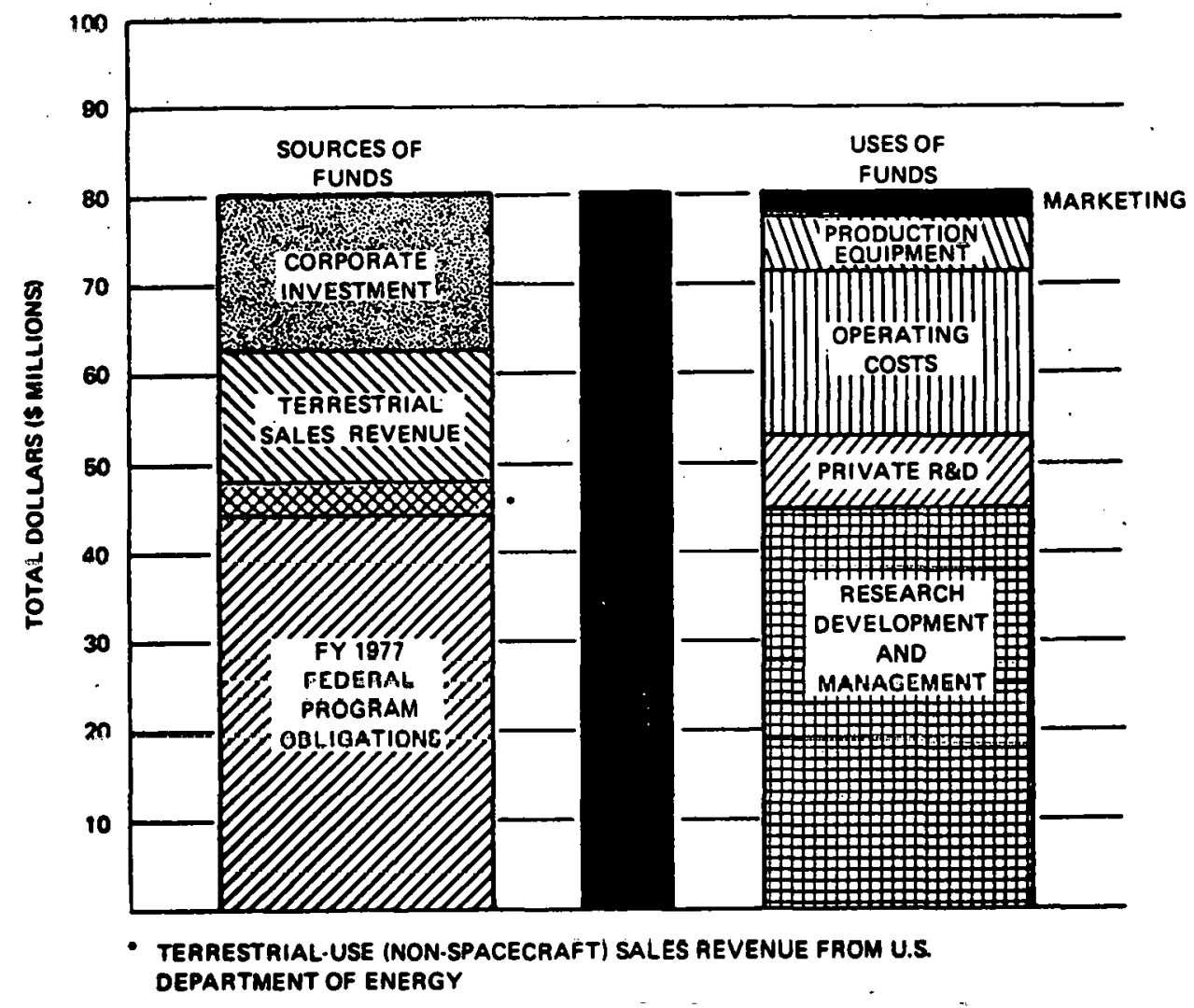

Figure A-1. ESTIMATE OF PHOTOVOLTAIC INDUSTRY: ANNUAL SOURCES AND USES OF FUNDS, 1977 [A-4, p. IV-26]

Over 30 companies presently are conducting photovoltaic activities. The commitments of these companies range from production and sale of photovoltaic modules to internal funding of research and development, to participation in federally funded $R \& D$. Companies with a wide variety of backgrounds have made some level of commitment to photovoltaics. The producing companies include three independent new companies, two 
energy company subsidiaries, two manufacturers of photovoltaic cells for space use, and one major electrical equipment and semiconductor firm. Companies whose commitment is presently limited to $R \& D$ include several semiconductor and electronics companies, hardware research-based companies, energy company subsidiaries, major materials suppliers, and new photovoltaic companies.

\section{A.7 REFERENCES}

Al. BDM Corporation. Photovoltaic Power Systems Market Identification, Draft Report. McLean, VA: BDM; May 1977.

A2. InterTechnology Solar Corporation. Photovoltaic Energy Technology Market Analysis, Draft Report. Warrentown, VA: ITC; January 1978.

A3. BDM Corporation. Photovoltaic Incentive Options, Preliminary Report. BDM/W-78-184-TR. McLean, VA: BDM; August 1978.

A4. Booz, Allen, and Hamilton, Inc. Assessment of Solär Photovoltaic Industry, Markets and Technologies, Draft Report. Bethesda, MD: Booz-Allen; September 1978.

A5. U.S. Department of Energy, Division of Solar Technology. Photovoltaic Program Summary. DOE/ET-0019/1. Washington, D.C.: U.S. DOE; January 1978.

A6. Costello, Dennis; Posner, David; Schiffel, Dennis; Doane, James; Bishop, Charles. Photovoltaic Venture Analysis. SERI/TR-52-040. Golden, CO: Solar Energy Research Institute; July 1978.

A7. Flaim, Silvio; et al. Economic Feasibility and Market Readiness, Draft Final Report. SERI/TR-52-055. Golden, CO: Solar Energy Research Institute; August 1978 .

A8. Weber, Walter F. Photovoltaics: An Industry Survey. Golden, CO: Solar Energy Research Institute; July 1978.

A9. Gnostic Concepts, Inc. Industrialization Study. Menlo Park, CA: 'Gnostic Conecpts; $\Lambda$ uguat 1878.

A10. U.S. Department of Energy. Photovoltaic Commercialization Task Force Report. Washington, D.C.: U.S. DOE; August 1978. 


\begin{tabular}{|c|c|c|c|}
\hline $\begin{array}{l}\text { Document Control } \\
\text { Page }\end{array}$ & $\begin{array}{l}\text { 1. SERI Report No. } \\
\text { TR-352-298 }\end{array}$ & 2. NTIS Accession No. & 3. Recipient's Accession No. \\
\hline \multirow{2}{*}{\multicolumn{3}{|c|}{$\begin{array}{l}\text { 4. Title and Subtitle } \\
\text { Photovoltaic Procurement Strategies: An Assessment of } \\
\text { Supply Issues }\end{array}$}} & $\begin{array}{l}\text { 5. Publication Date } \\
\text { February } 1980 \\
\end{array}$ \\
\hline & & & 6. \\
\hline \multicolumn{3}{|l|}{ 7. Author(s) } & 8. Periorming Organization Rept. No. \\
\hline \multicolumn{3}{|c|}{ David Posner, Dennis Costello } & \\
\hline \multirow{3}{*}{\multicolumn{3}{|c|}{$\begin{array}{l}\text { 9. Performing Organization Name and Address } \\
\text { Solar Energy Research Institute } \\
1617 \text { Cole Boulevard } \\
\text { Golden, Colorado }\end{array}$}} & 10. Project/Task/Work Unit No. \\
\hline & & & $\begin{array}{l}\frac{3825.50}{\text { 11. Contract (C) or Grant (G) No. }} \\
\text { (C) }\end{array}$ \\
\hline & & & (G) \\
\hline \multirow{2}{*}{\multicolumn{3}{|c|}{ 12. Sponsoring Organization Name and Address }} & $\begin{array}{l}\text { 13. Typo of Roport \& Reriud Cuvered } \\
\text { Technical Report }\end{array}$ \\
\hline & & & 14. \\
\hline
\end{tabular}

15. Supplementary Notes

16. Abstract (Limit: 200 words)

This review report presents the results of an analysis of alternative approaches to the design of a federal photovoltaics procurement program. Advantages and disadvantage $\beta$ of large purchases at fixed prices and smaller purchases for testing and demonstrating the technology are presented. The objectives and possible impacts of these purchase programs on the photovoltaic industry are described. The reactions of the industry to alternative purchase programs were assessed using personal interviews with selected companies currently active in photovoltaics. . The report begins with a review of the impacts of federal procurements on other innnvatinns, including the clectronics industry, and suggests the relation of these pronurements to photovoltaica. The methodology for conducting the interviews is presented next. The results of the interviews are summarized into possible scenarios of future developments in the industry and into discussions of key issues in the design of a procurement program. An appendix on the current structure of the photovoltaic industry is provided.

17. Documant Analysis

a. Descriptors Photovoltaics; Solar Cells; Procurement; Policy; Industry; US DOD; NASA; Surveys;.Methodology; Federal Government; Economic Impact; Contracts; Risk; Semiconductor Devices

b. Identifiers/Open-Ended Terms

c. UC Categories

$63 a$

18. Availability Statement

National Technical Information Service

U. S. Department of Commerce

5285 Port Royal Road

Springfield, Virginia 22161 